\title{
The role of media convergence in Kurdish Dialects Rudaw Network Media as a samples
}

Hunar M.Hussein ${ }^{l}$

Received: May 01, 2016

Reviewed: May 08, 2016

Accepted: May 21, 2016

\begin{abstract}
The present research is an attempt to find a solution bringing Kurdish dialects closer and updating its vocabularies. In this matter all Kurdish dialects (Kurmanci, Sorani and Zazaki) should be united into one formal Standard Language. As well known, the dialects of any language meets its formal interests. Thus, the linguists confess the fact that all the human languages have dialects including every one while speaking his own 'individual' spoken style. Besides, the Kurdish language should be raised to a standard to be comparable to International Standard. It should be based on the scientific systems to meet the benefit of the vocabularies uniting the Kurdish vocabularies as well as phonetic and seeking to reunite the Kurdish people. Obviously, the media and the press have great influence on languages and human development in all fields. Language and the identity are the most important global depiction of any people living on earth. (ich habe den Satz verändert, aber ich weiß nicht, ob der Kontext derselbe ist, was wolltest du damit sagen? der vorherige sATZ HATTE keinen Sinn). In spite of the attempt to assimilate the Kurdish language by different political processes the Kurdish language was not to put an end. By request of Kurdish existence the kurdish politicians and intelectuals has been struggling against the above mentioned systems for the Kurdish human beings. But one should not neglect the lingual rule of Mr. Madhat Badirkhan and the government of Kurdistan region in developing the Kurdish Language. As a result of the global free transformation on Media in Iraqi Kurdistan, the Rudaw TV is a real symbol and network to have been chosen as a sample for the recent research. Undoubtly, there are some reasons to chose Rudaw TV and these reasons are:

- It is the most popular TV in Kurdistan

- Sending its programs in different dialects

- Became an International TV
\end{abstract}

\section{Recommended citation:}

Hussein, H. M. (2016). The role of media convergence in Kurdish Dialects Rudaw Network Media as a samples. International Journal of Kurdish Studies 2 (3), 80- 107.

\footnotetext{
${ }^{1}$ Assist Lecture, Cihan University, Erbil, Translation Department. 99 Zanko -Erbil- Iraq Hunar.kurd@yahoo.com
} 


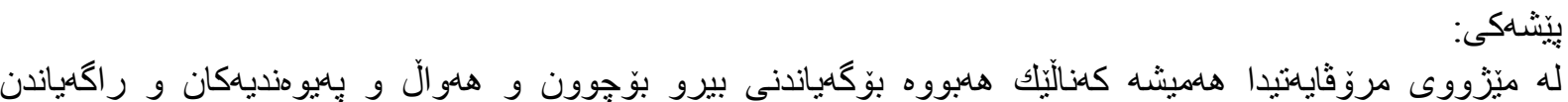

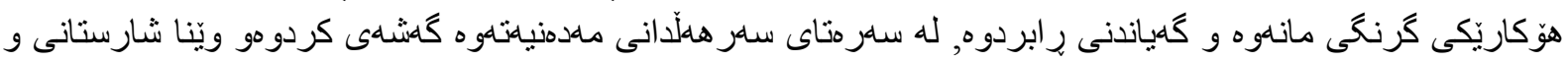

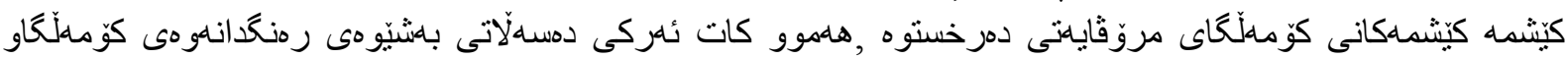

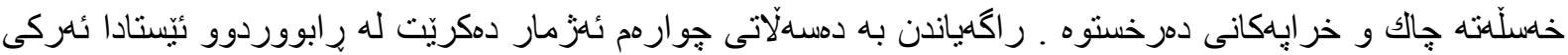

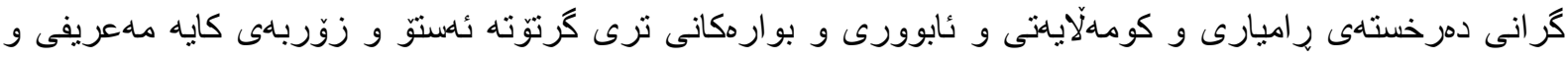

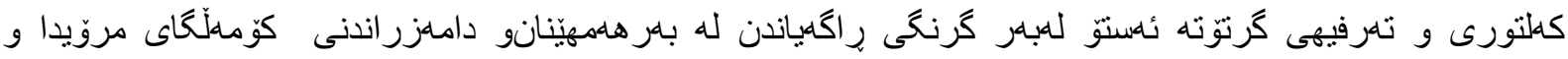

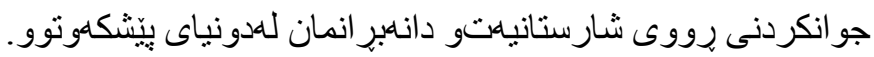

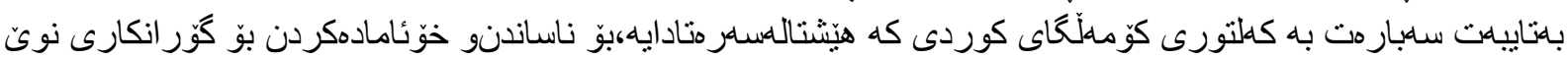

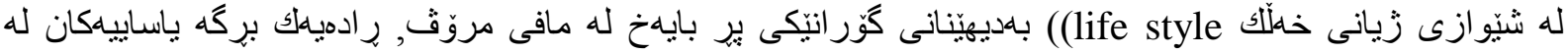

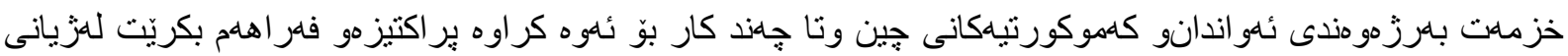

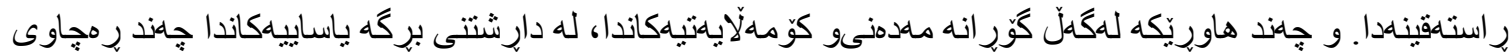

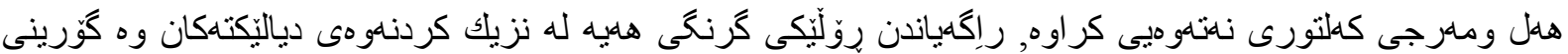

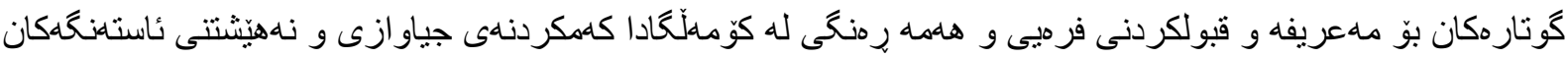

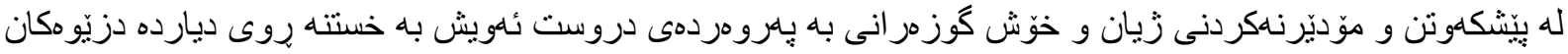

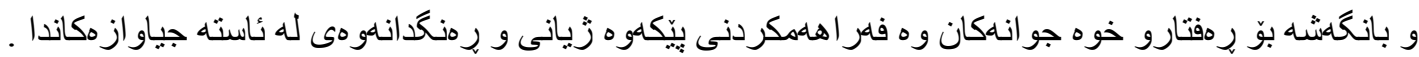

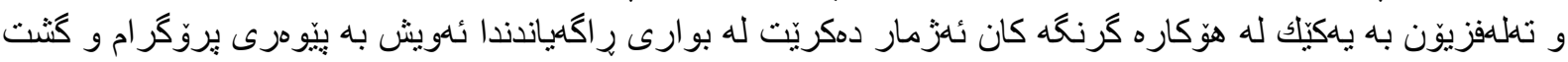

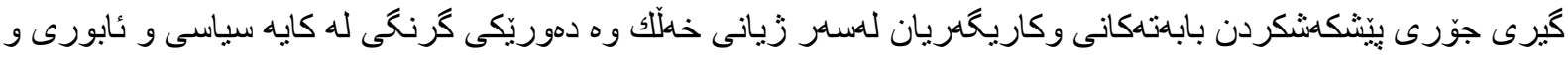

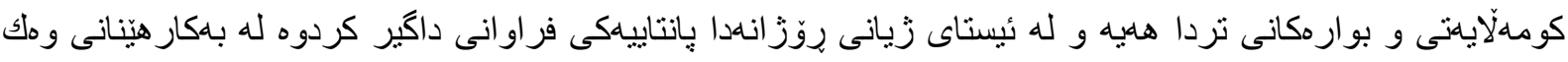

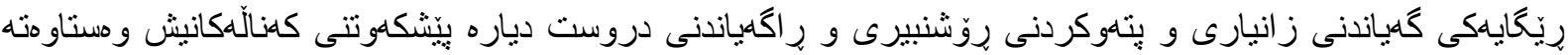

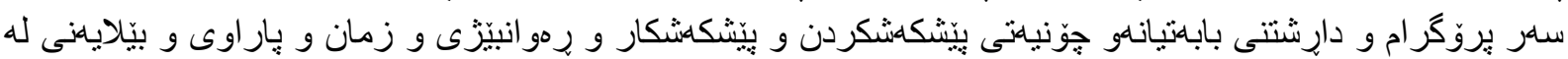

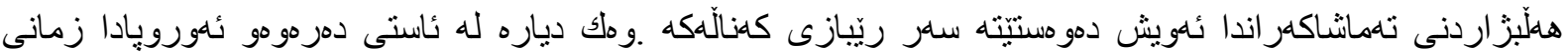

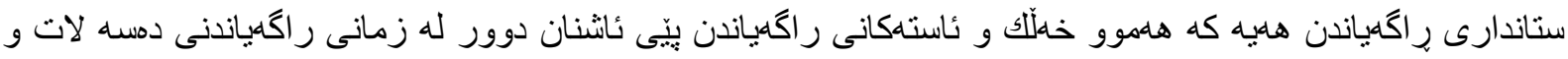

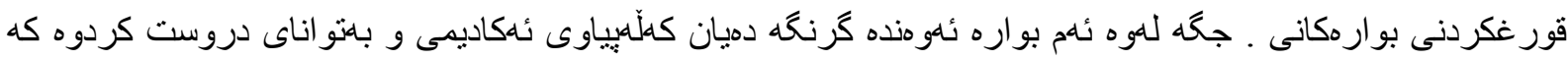

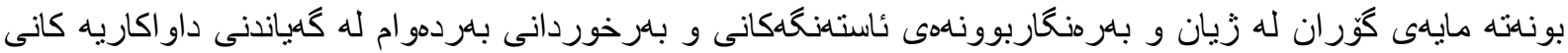

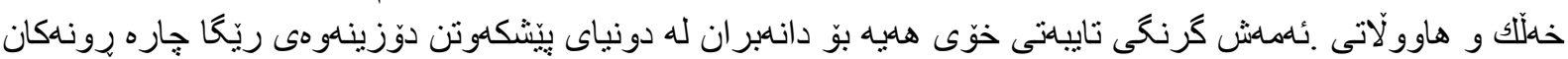

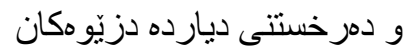

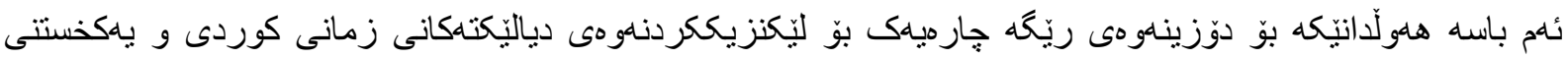

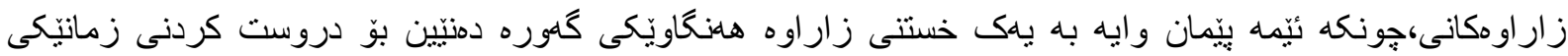

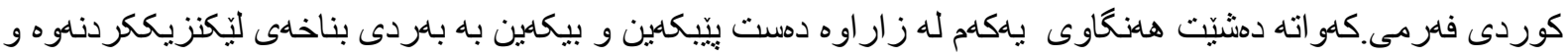

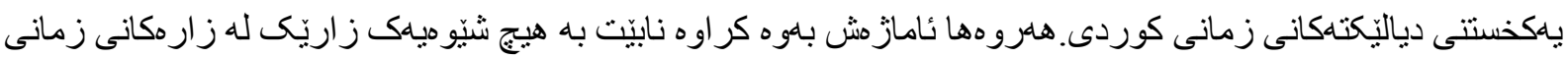

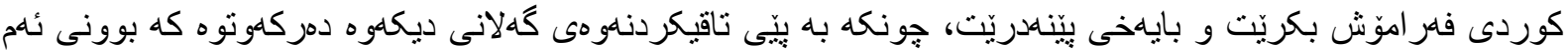

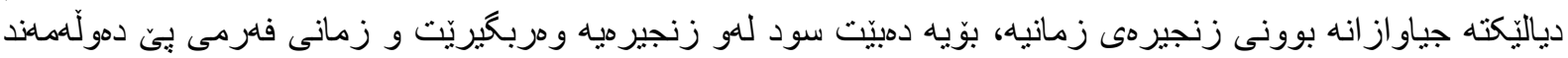

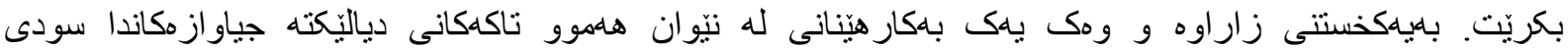

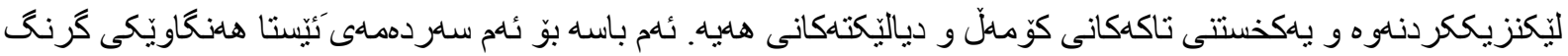

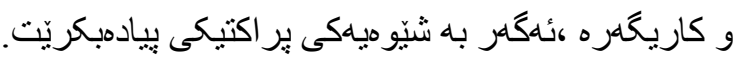

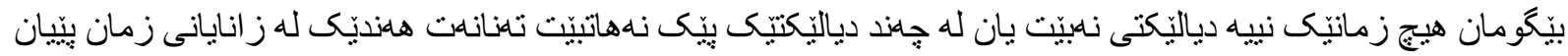

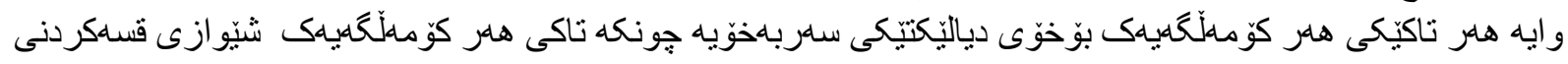

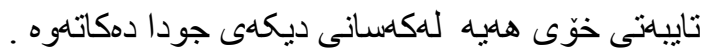

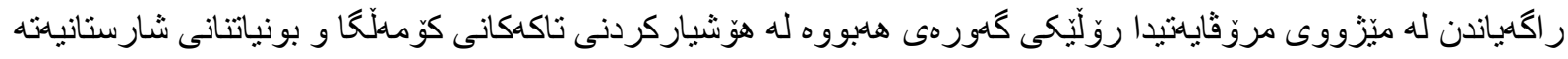

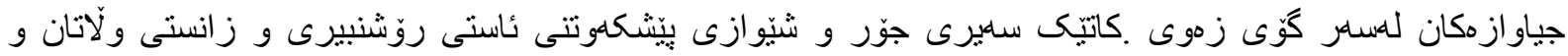

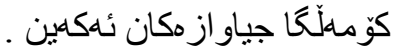




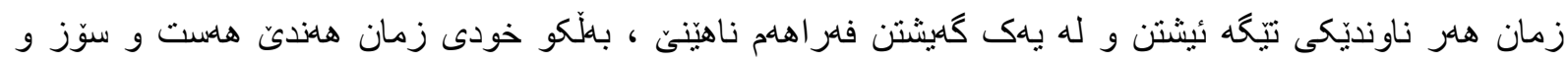

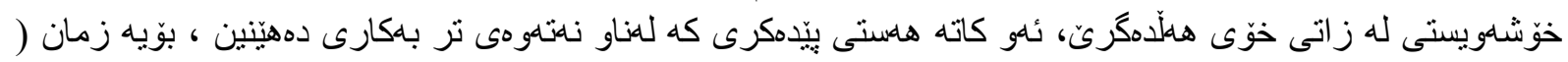

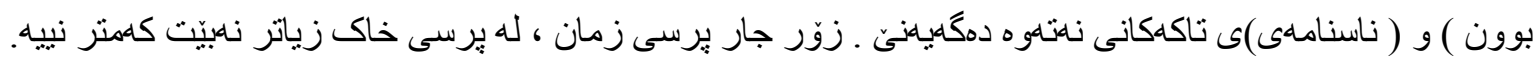

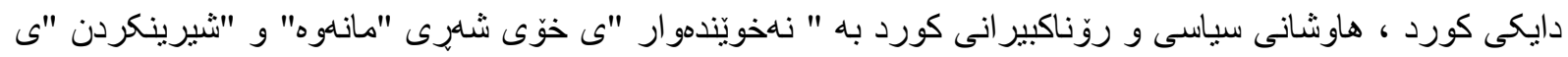

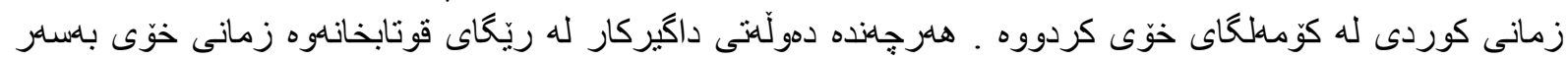

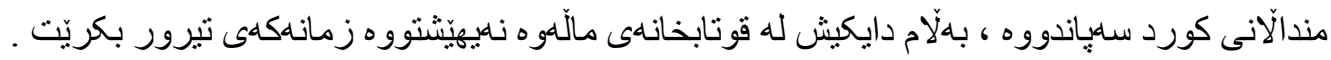

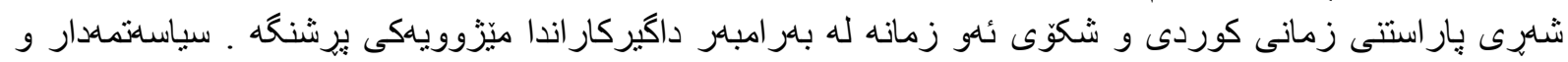

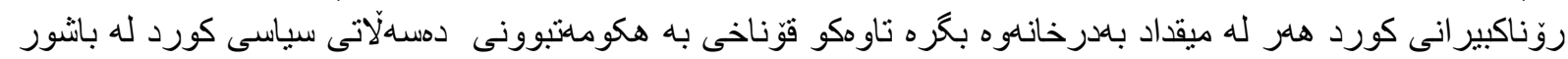

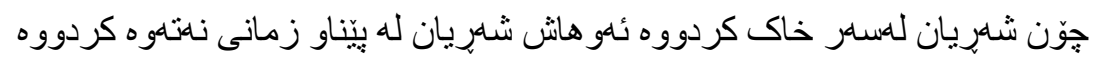

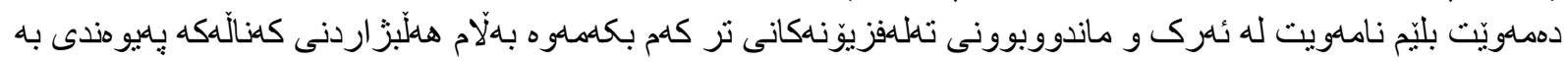

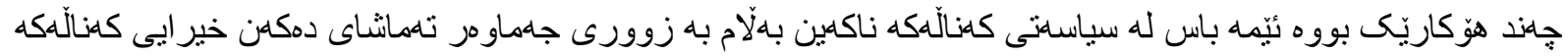

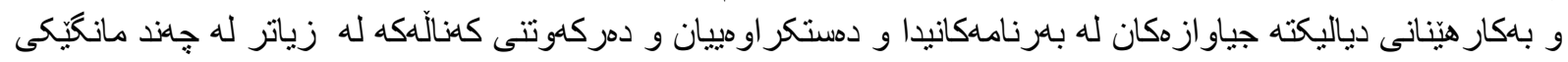

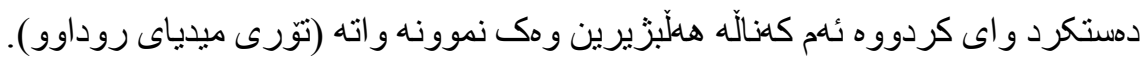

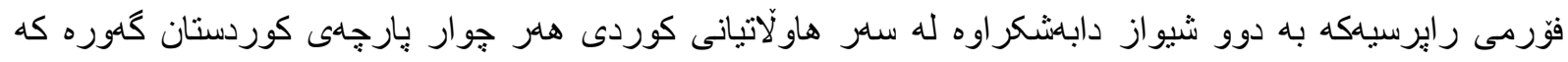

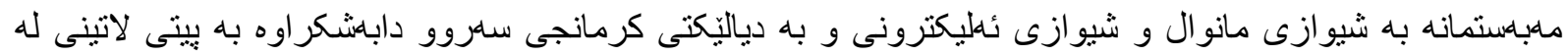

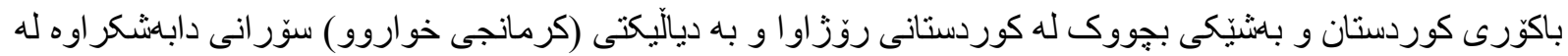

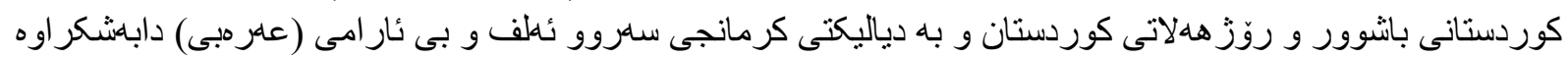

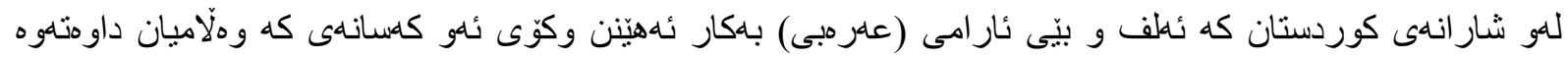

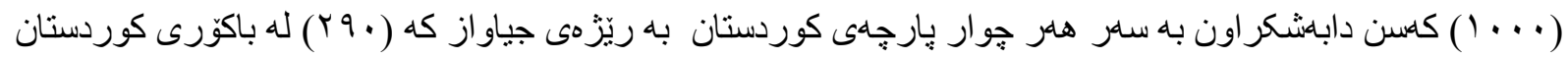

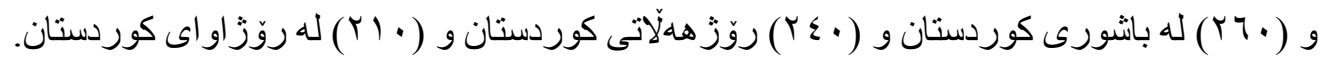

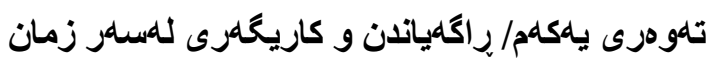

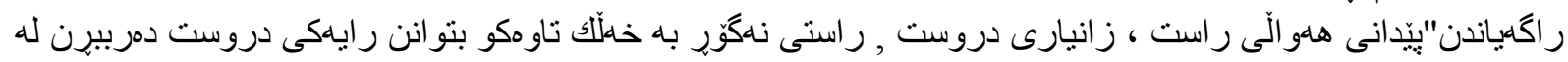

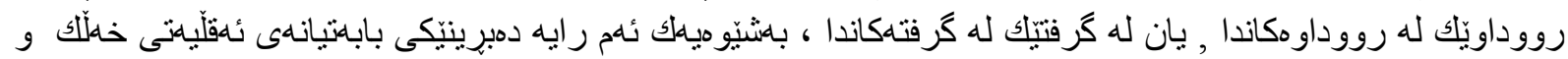

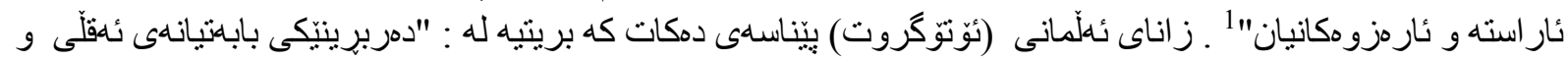

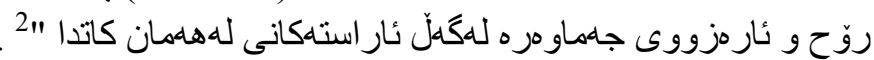

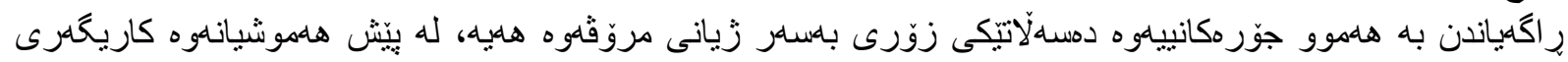

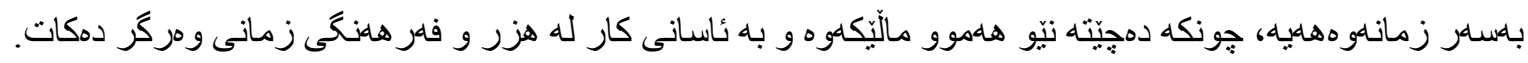

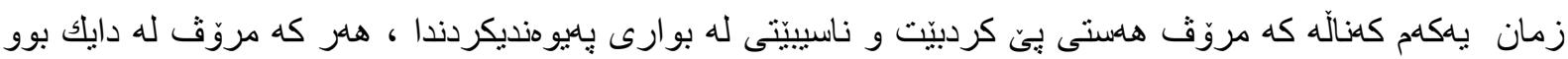

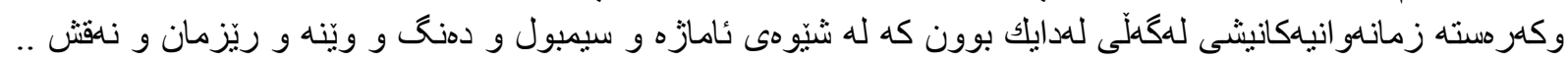

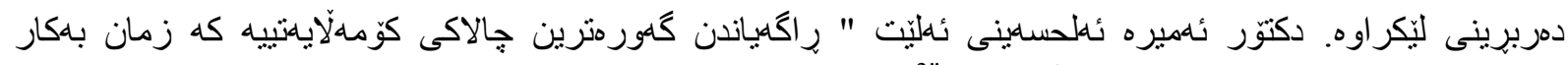

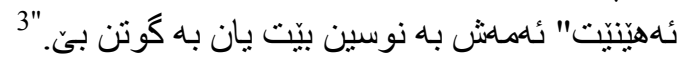

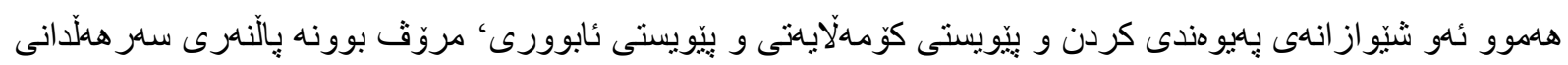

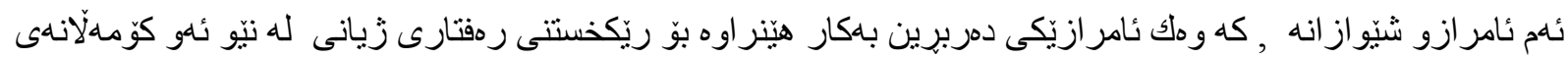

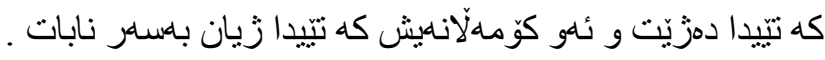

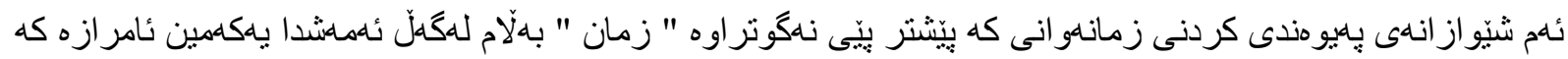

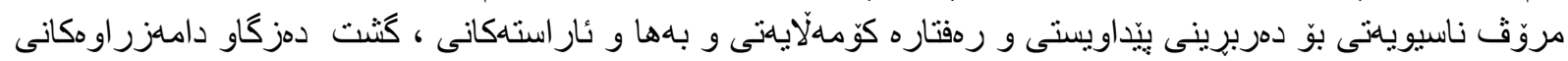

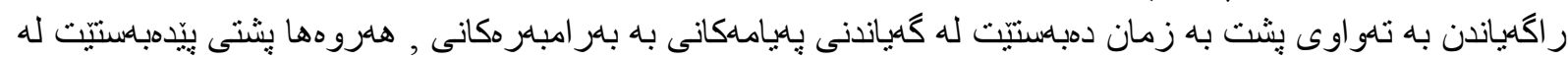

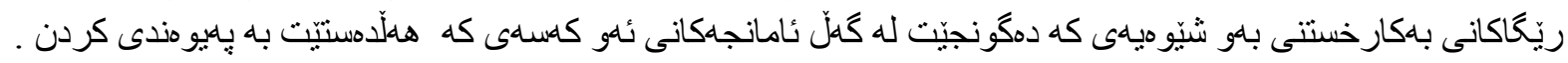




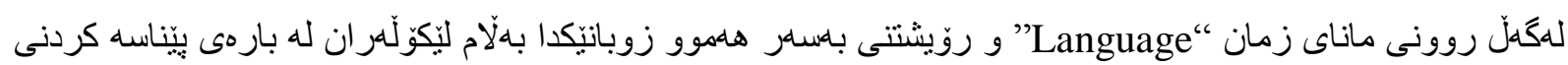

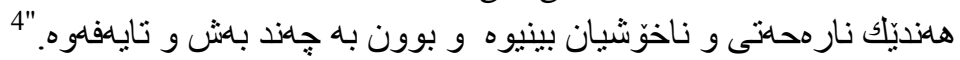

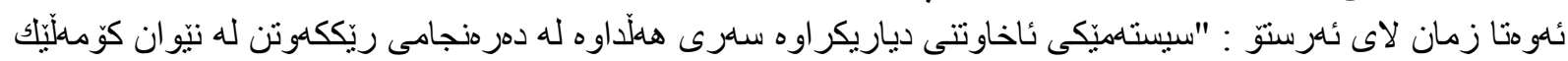

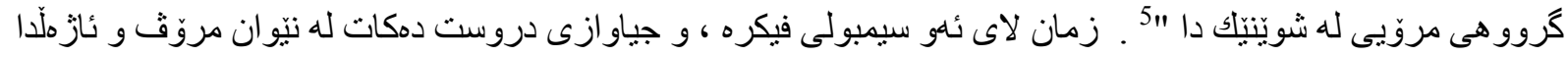

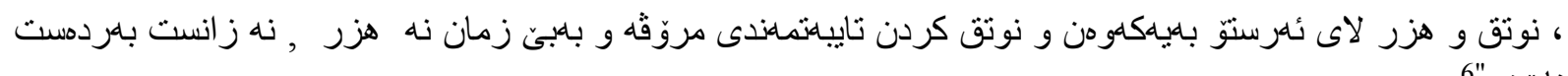

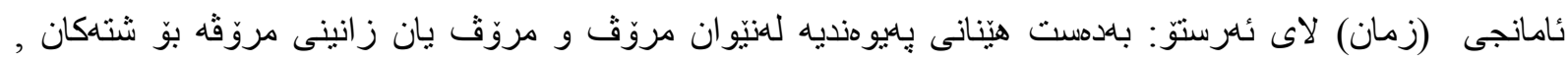

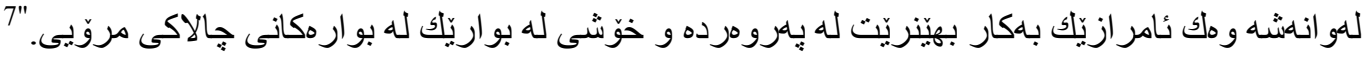

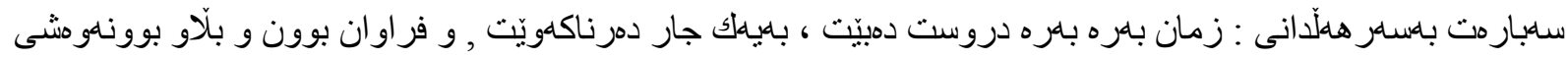

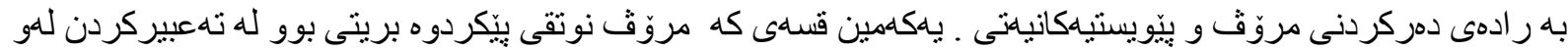

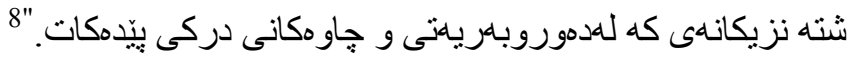

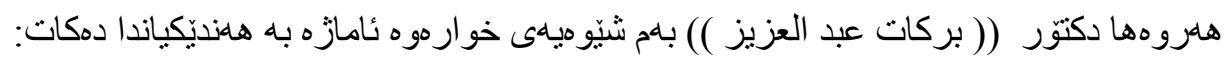

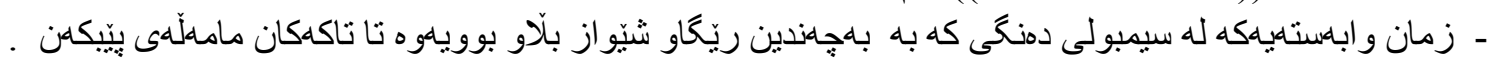

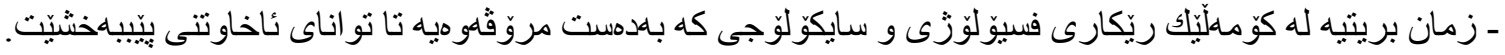

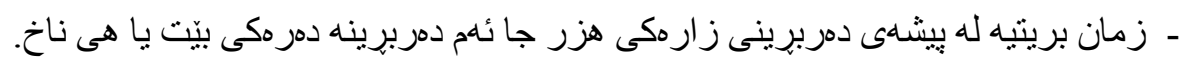

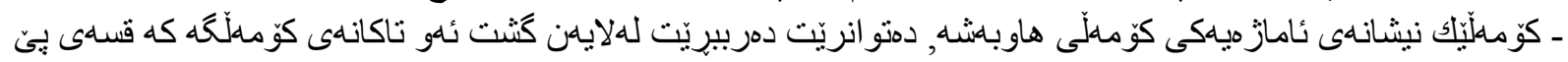

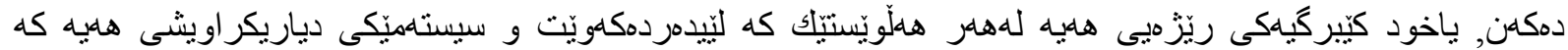

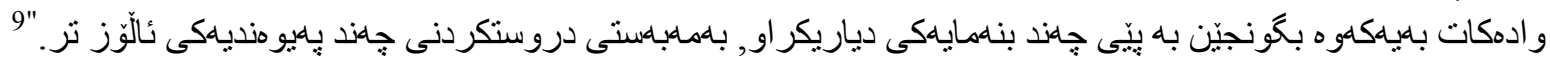

1ـ د. عبد اللطيف حمزة (1984) الإعلام والدعاية ، الهيئة المصرية للكتاب ، طبعة 2 ،ل 75.

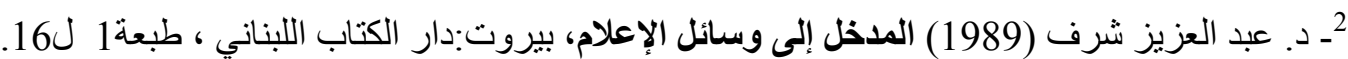

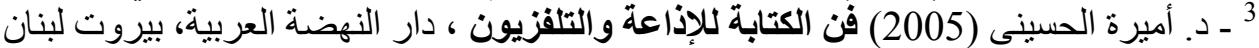

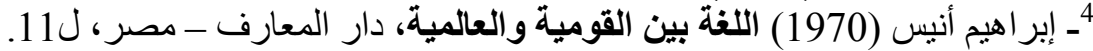

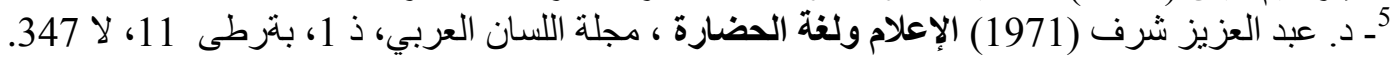

6 ــ د. محمد غنيمي هلال(1989) النقل الأدبي الحديث ، مكتبة نهضة مصر ، القاهرة ، ل 42.

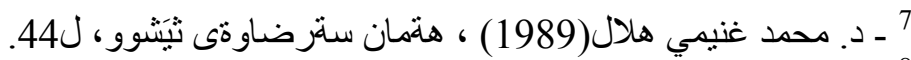

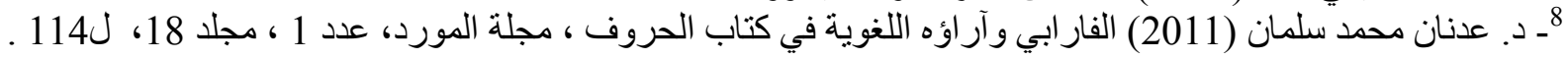
9 ـ ـ أ.د : سامي الشريف ــد. أيمن منصور ندا (2004) اللغة الإعلامية ( المفاهيم- الأسس ـ التطبيقات ) جامعة القاهرة

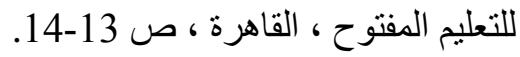

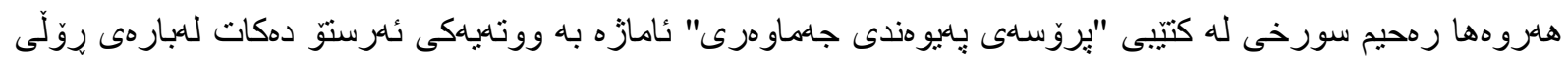

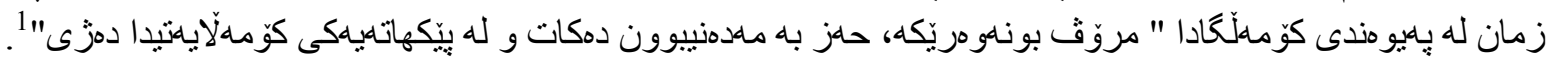




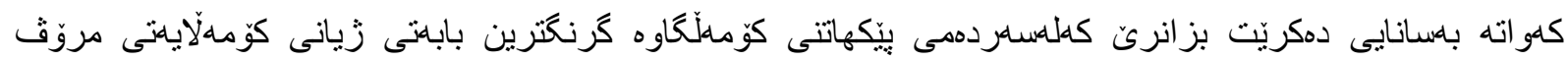

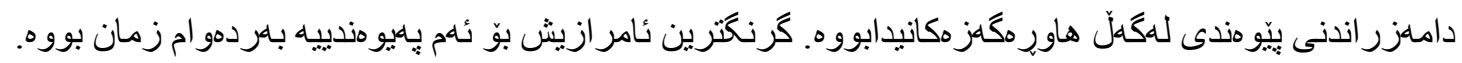

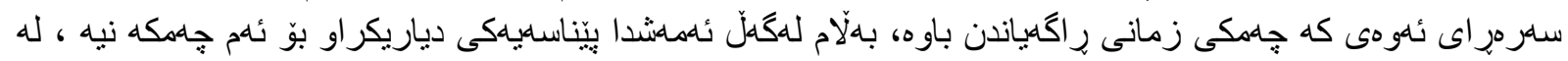

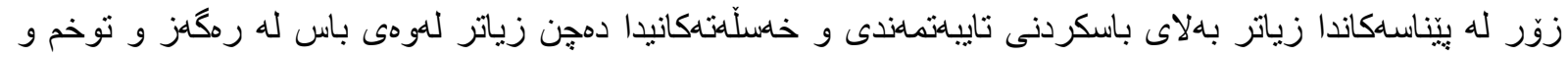

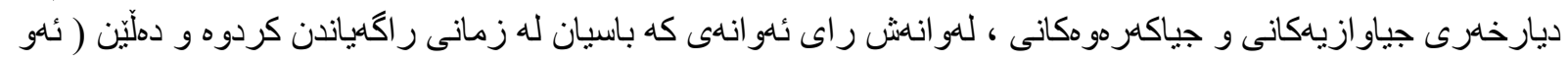

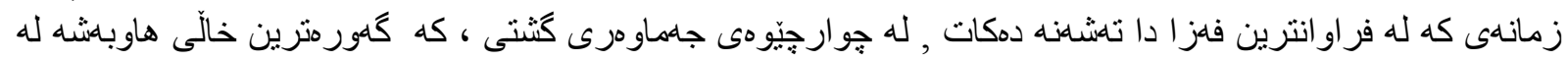

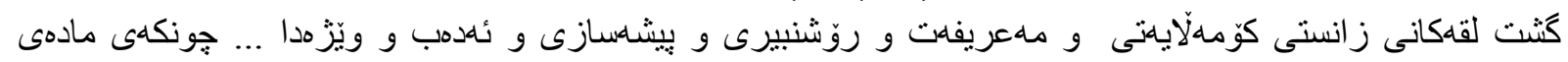

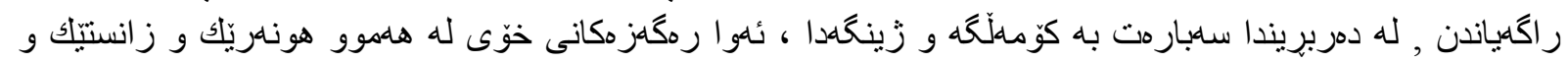

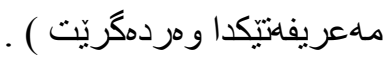

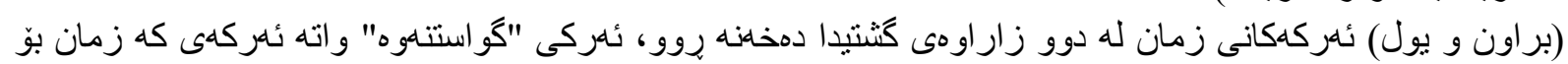

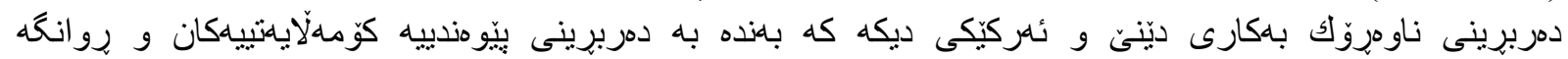

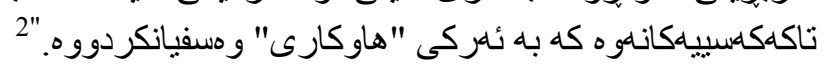

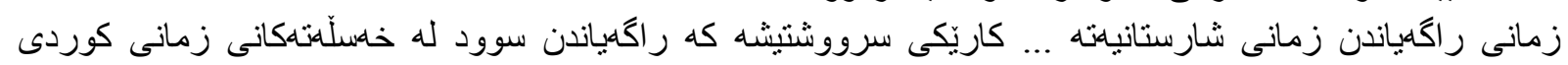

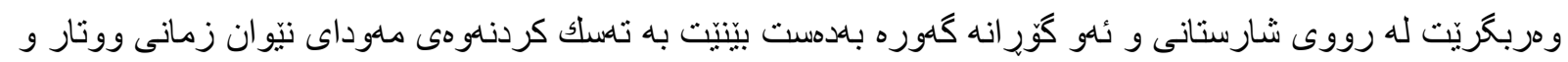

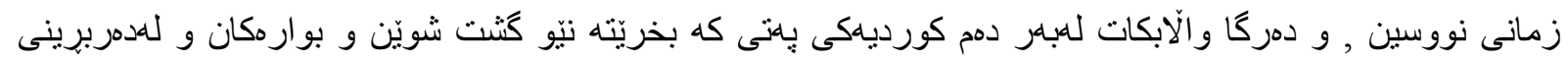

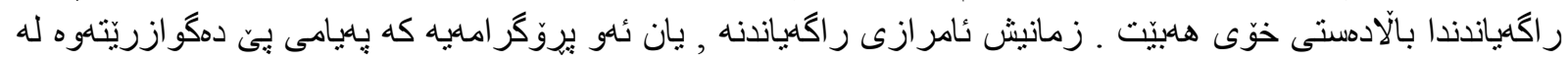

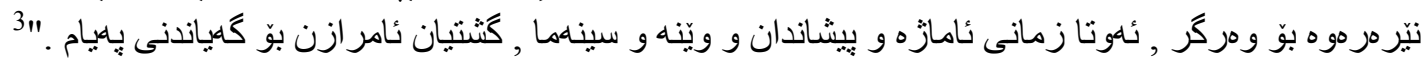

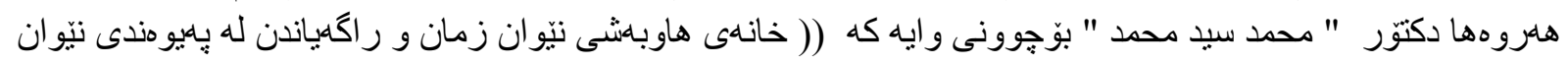

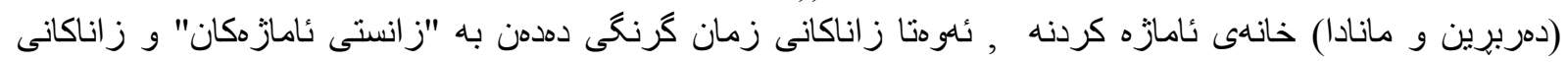

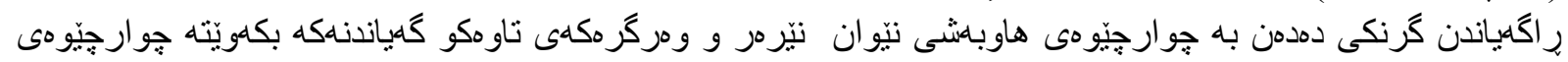

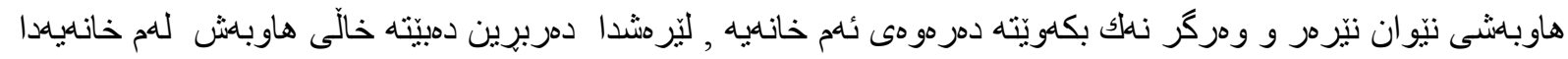

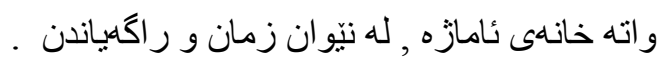

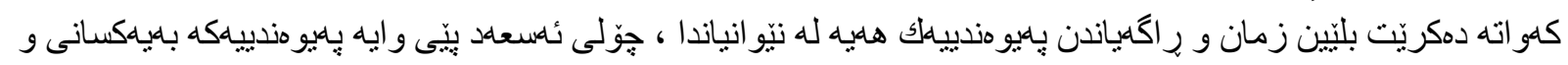

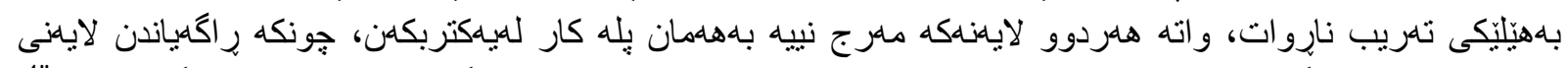

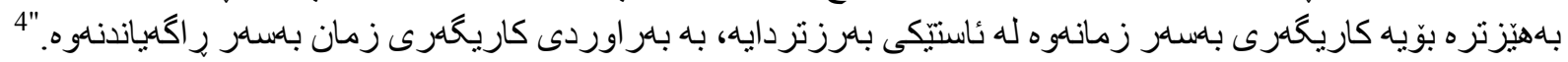

\section{رينووس و رِاكَياندن}

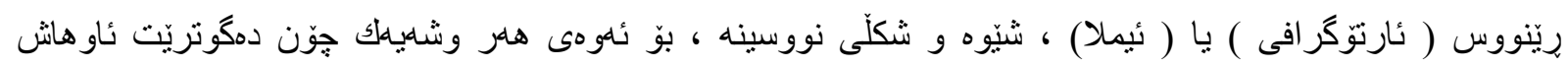

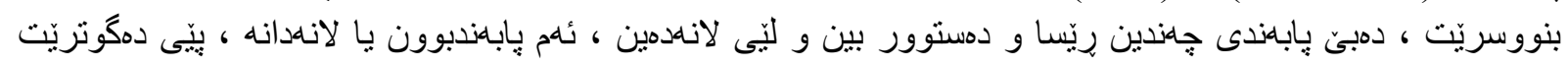

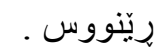

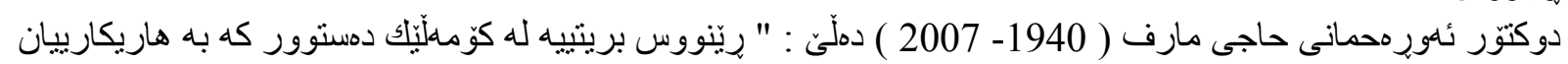

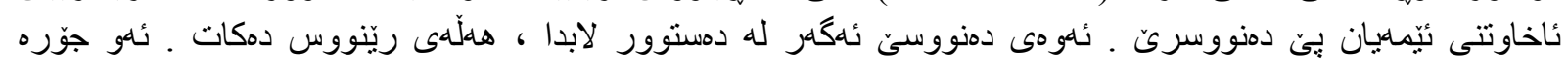

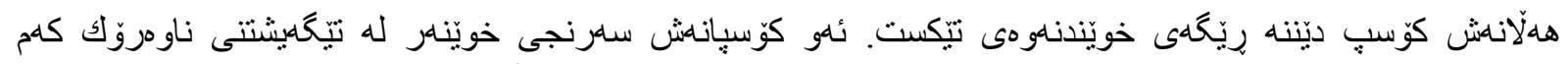

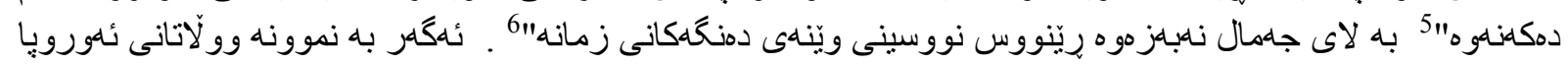

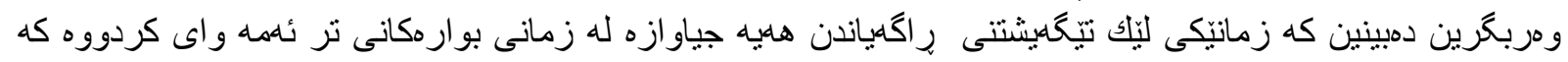

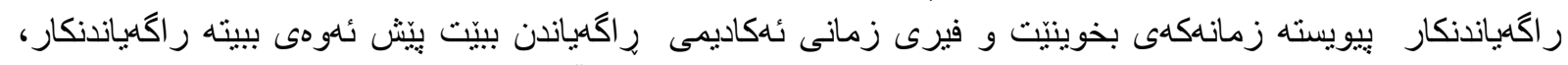

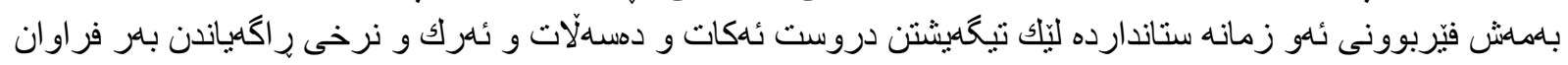

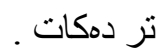




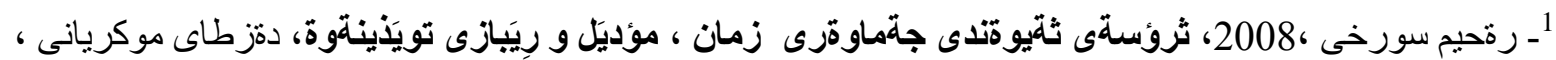

Brown. G and Yul. G 1983: Discourse Analysis, Cambridge University press. 3ـ أ.د : سامي الثريف ـ د. أيمن منصور ندا ، اللغة الإعلامية ( المفاهيمـ الأسس - التطبيقات ) جامعة القاهرة للتعليم

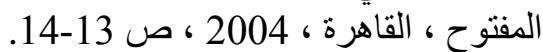

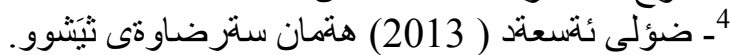

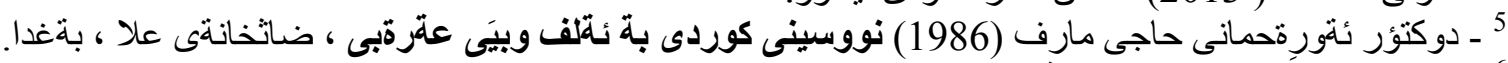

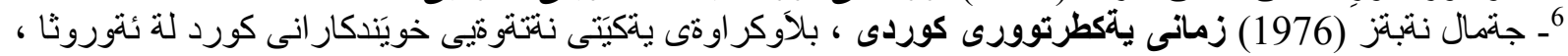

ئقةَّمانبا

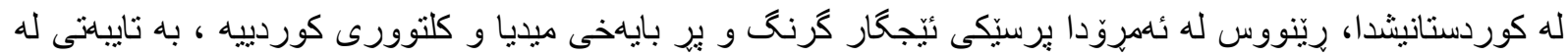

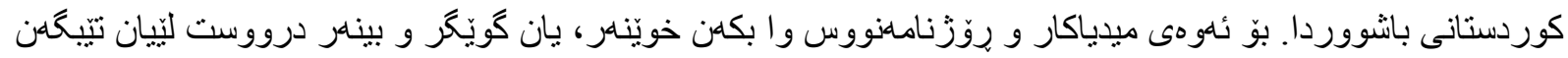

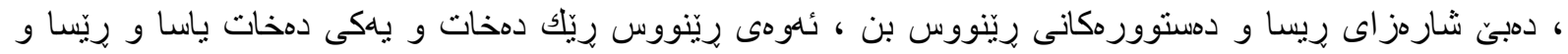

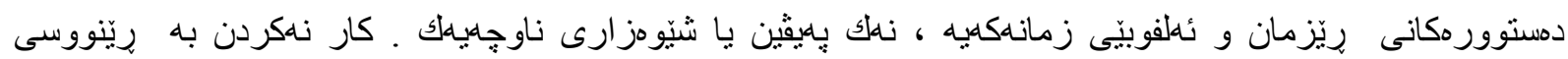

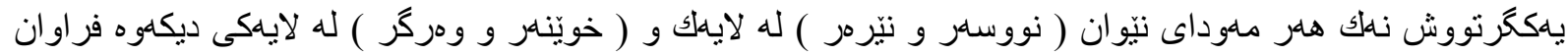

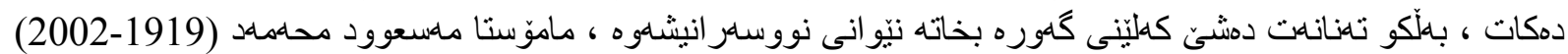

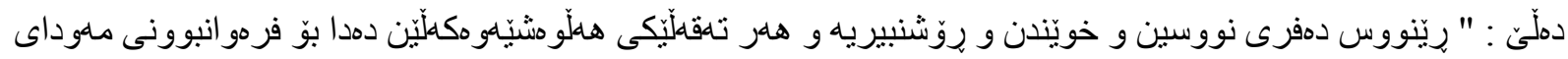

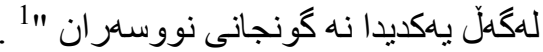

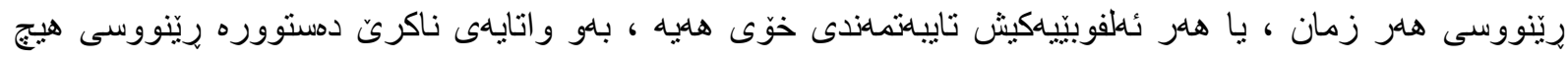

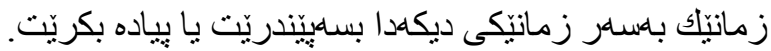

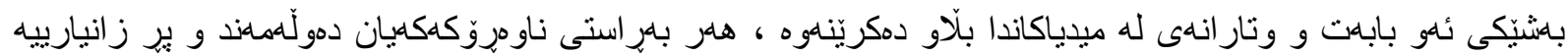

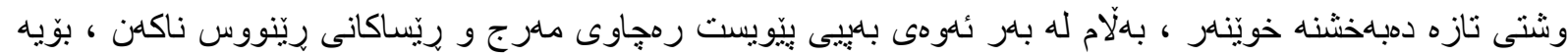

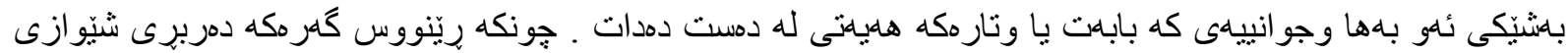

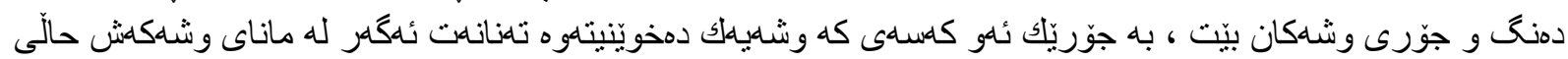

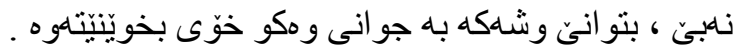

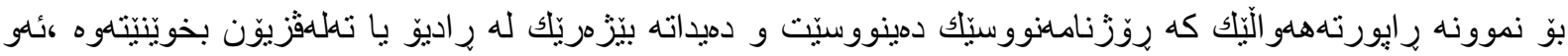

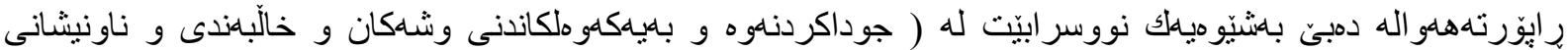

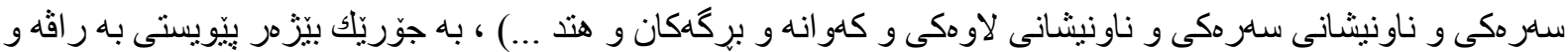

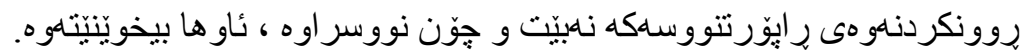

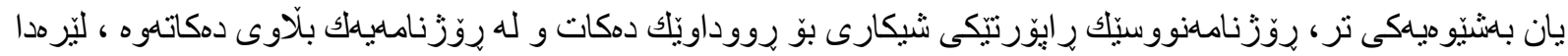

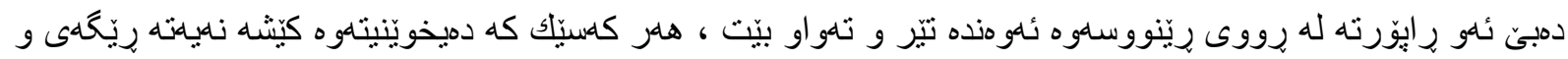

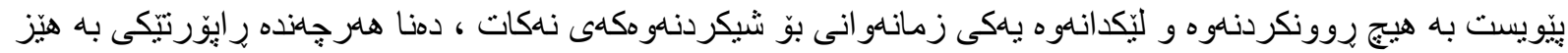

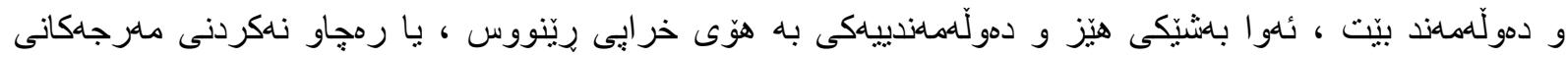

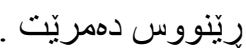

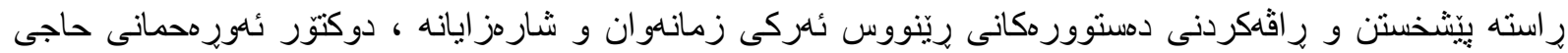

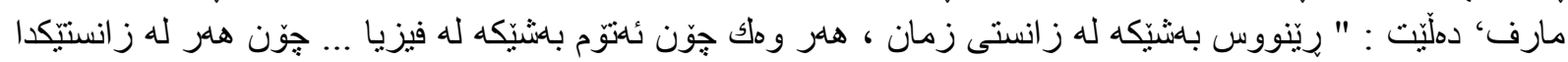

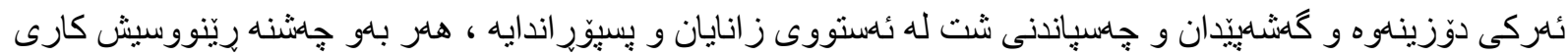

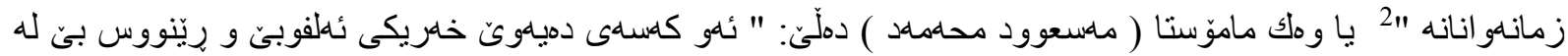

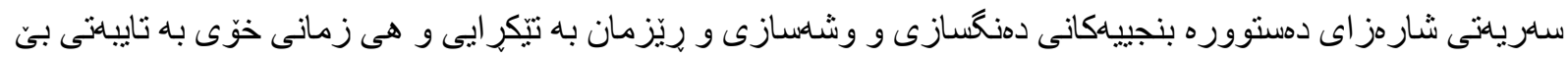

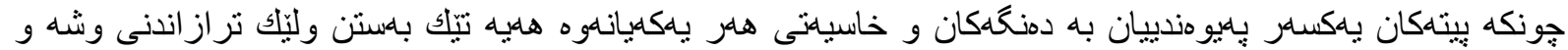

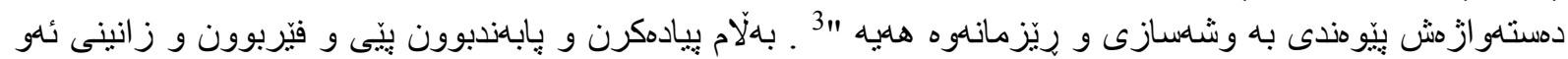

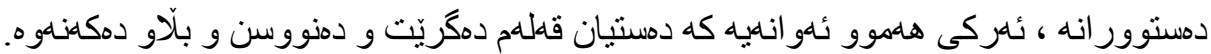

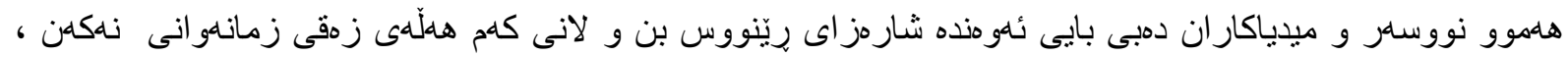

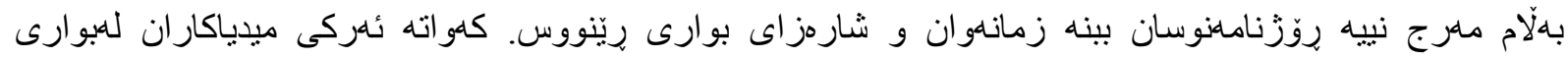




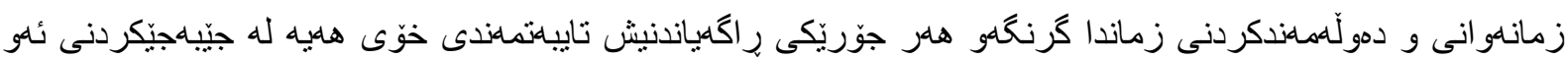

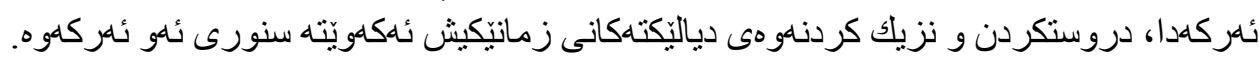

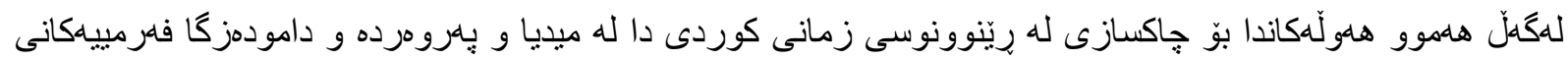

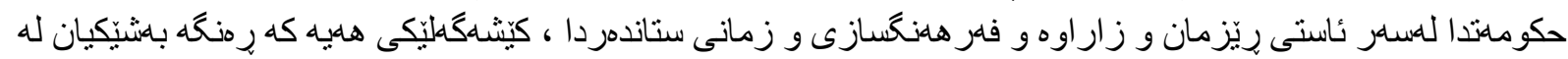

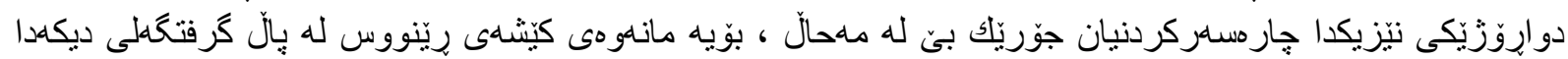

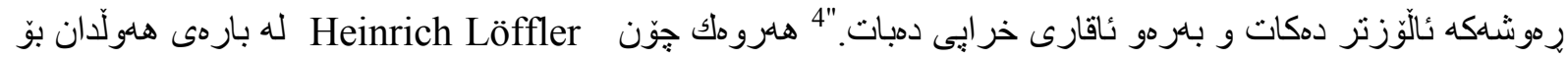

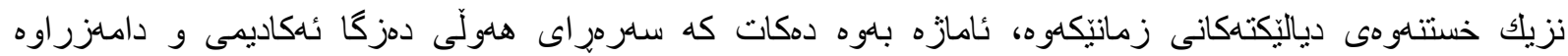

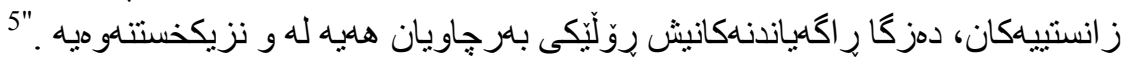

تهوهرى دووهم/ توّرى ميدياييى يروداو و كاريخهرى للمسلر ليّكنزيككردنهوهى دياليّكتهكان

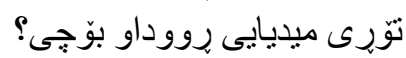

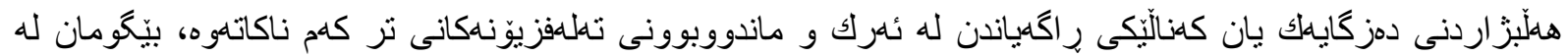

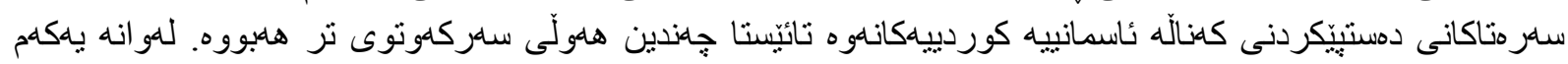

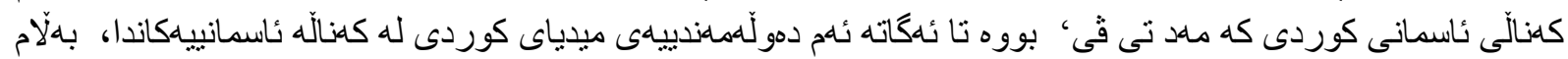

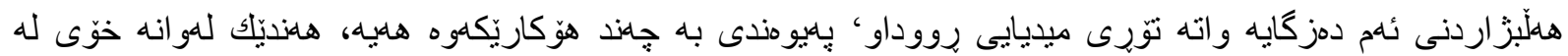

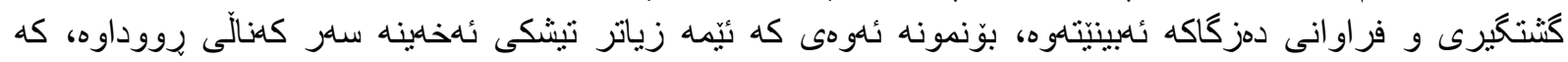

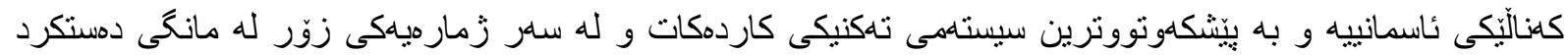

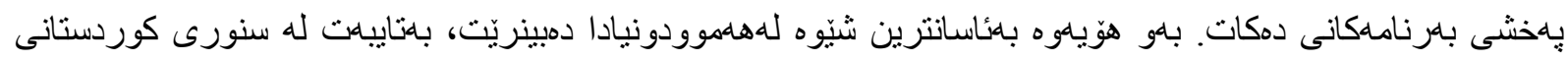

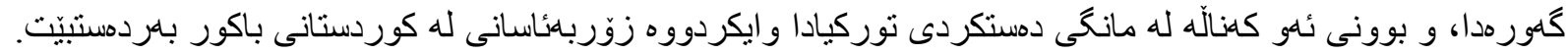

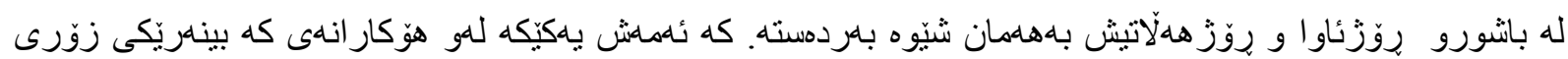

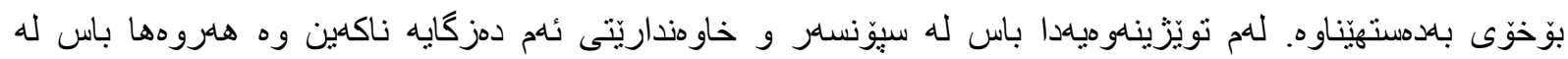

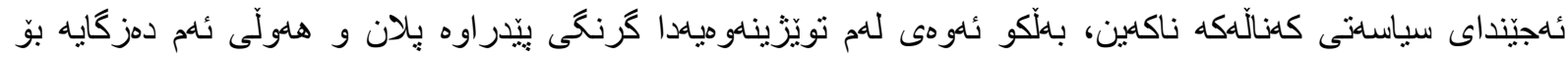

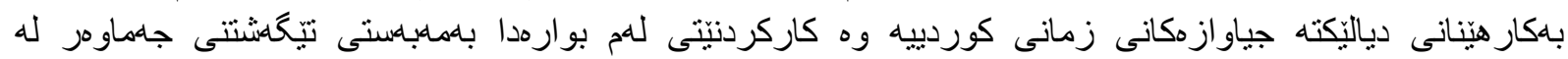

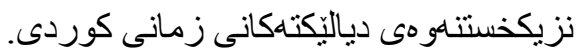

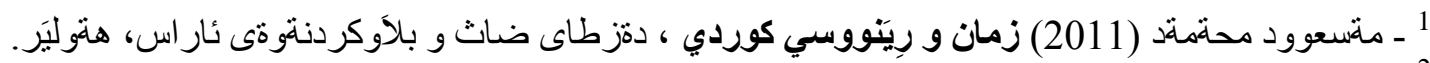

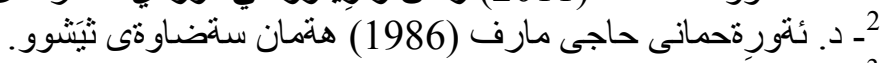

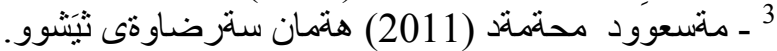

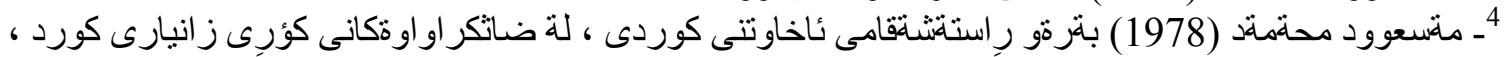

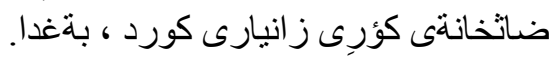

DIALEKT UND STANDARD IM MEDIENZEI TAL TER, (2006) Heinrich Löffler - 5

Mannheim, p16

تورى ميديايى ريووداو جى يه؟ 


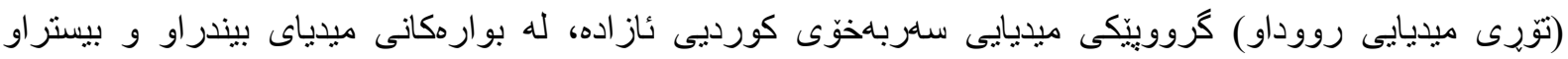

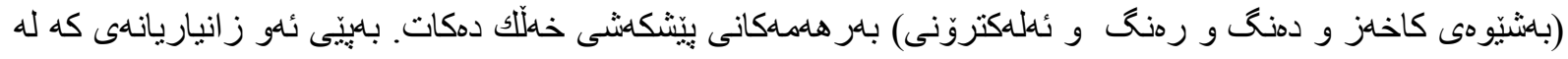

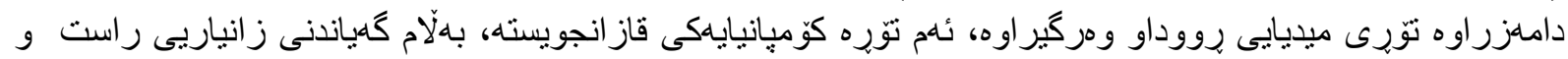

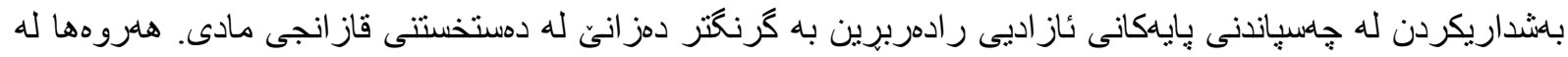

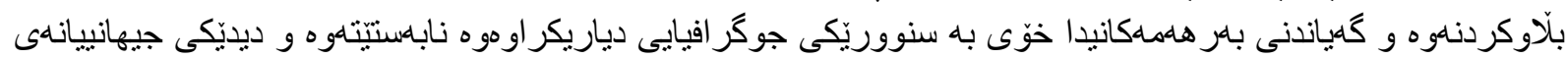
هليه بوّ كاركردن.

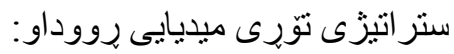

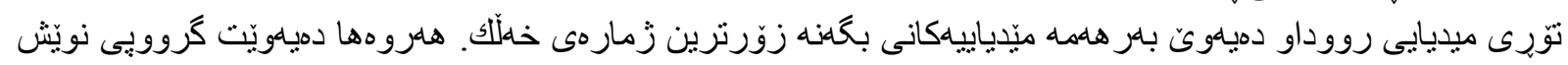

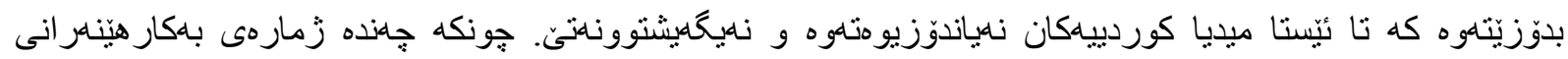

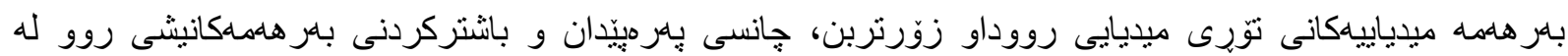

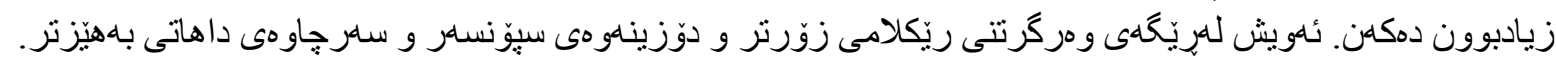

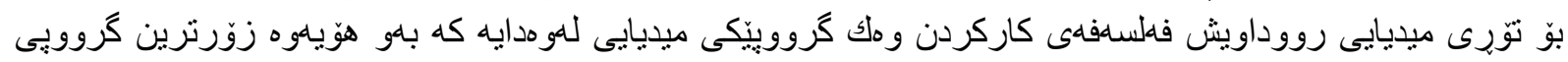

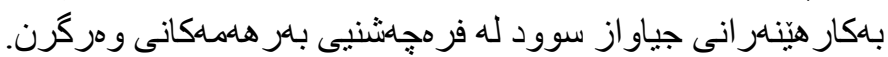

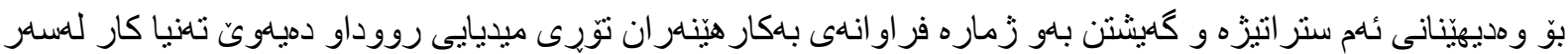

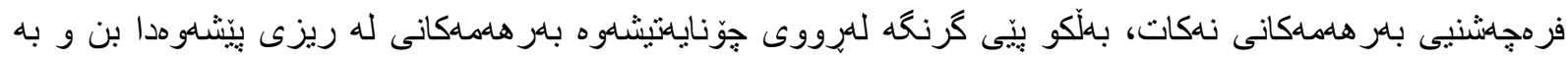

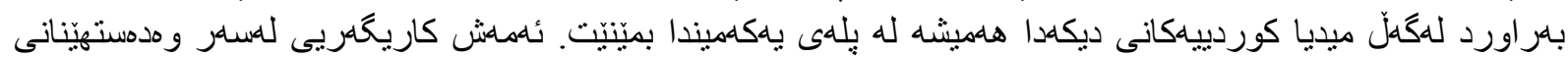

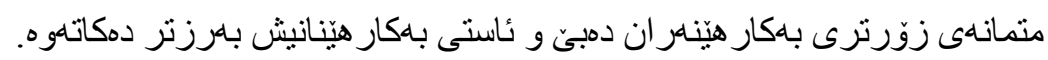

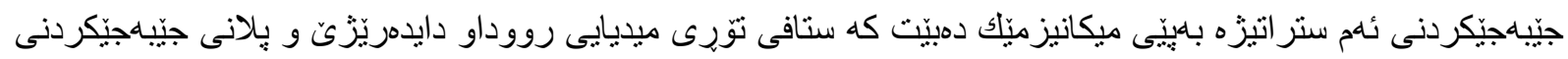
بوّ دادهنيّت.

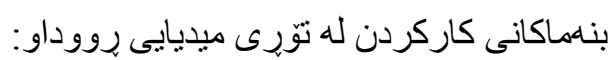

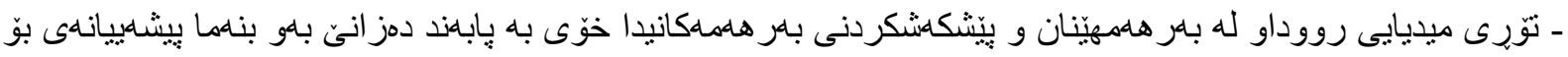

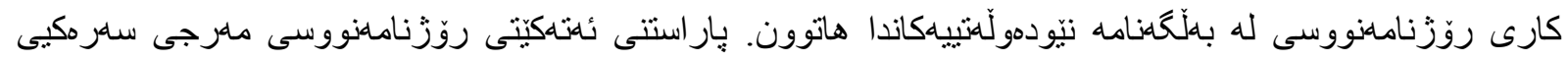

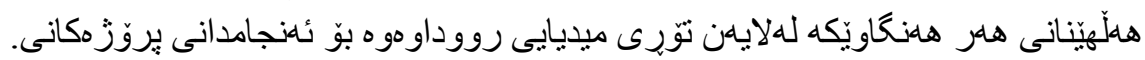

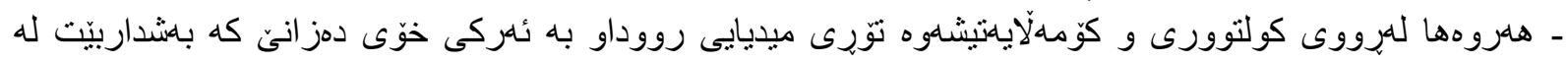

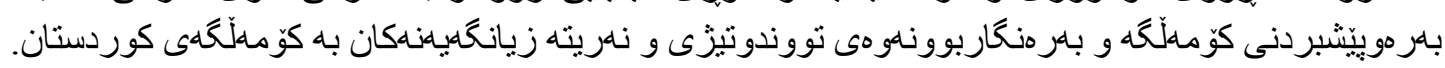

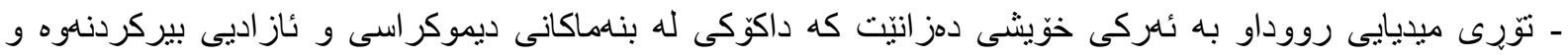

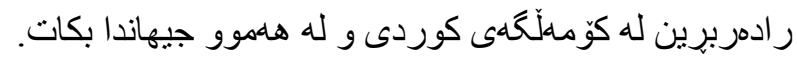

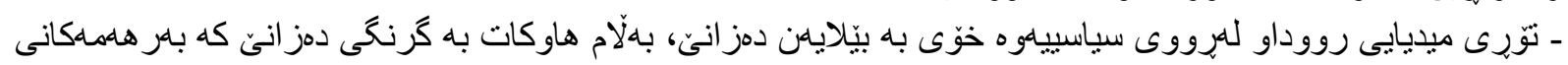

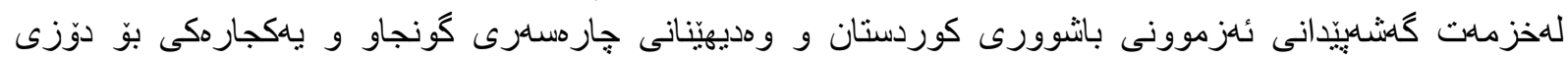

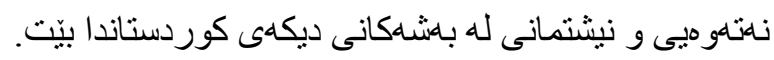

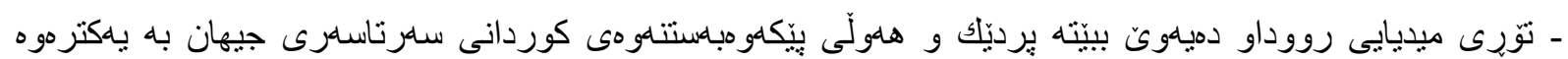

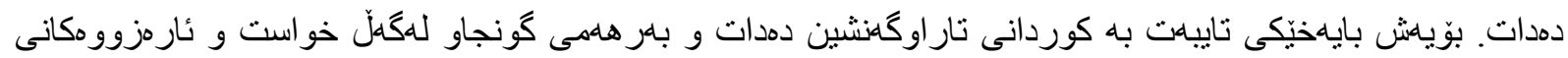

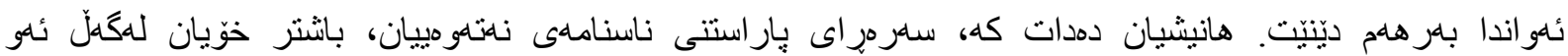

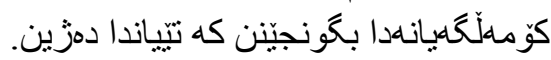

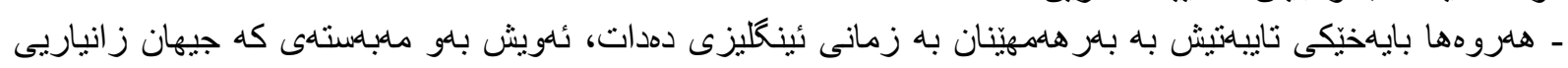

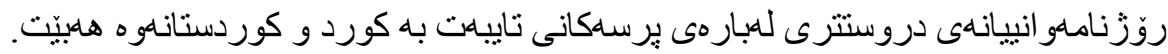

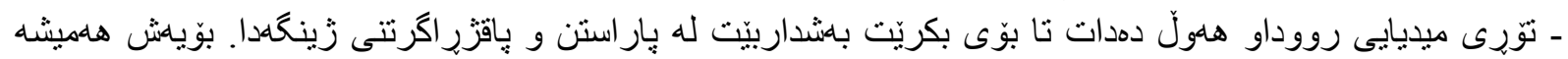

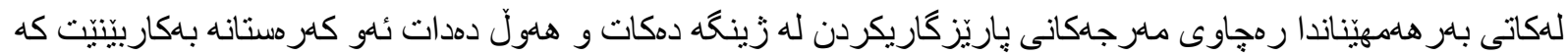

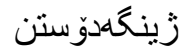

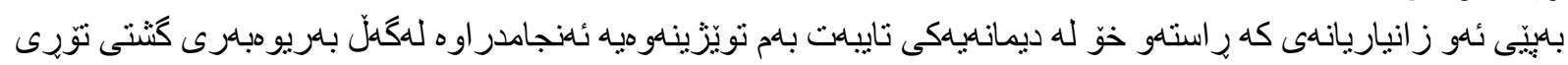

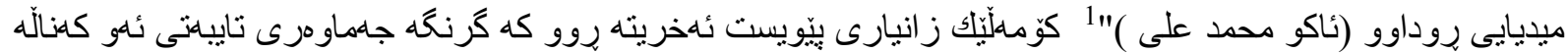
ئاكاداريين. 


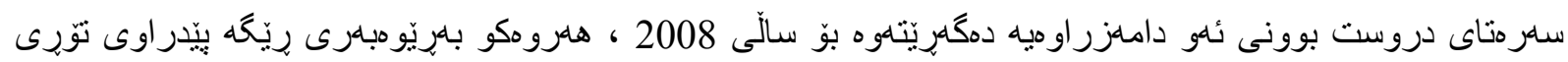

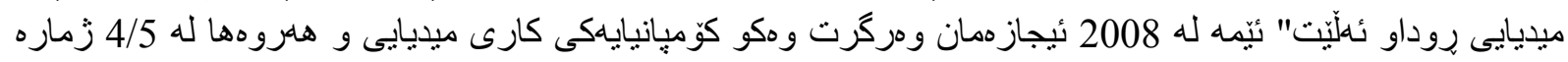

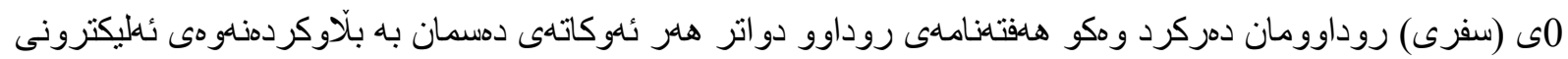

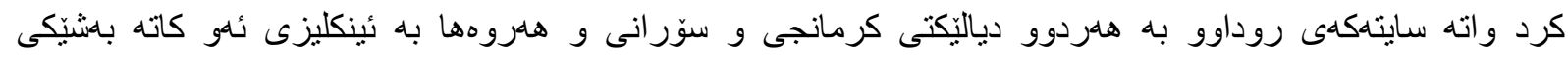

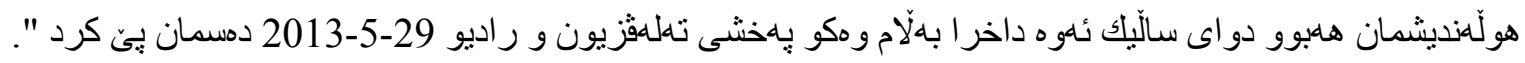

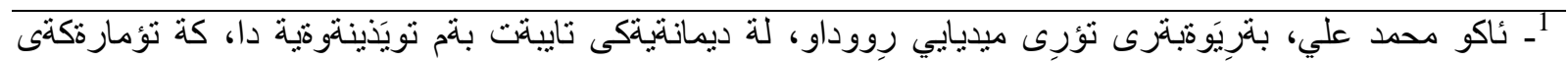
ثاريَزراوة.

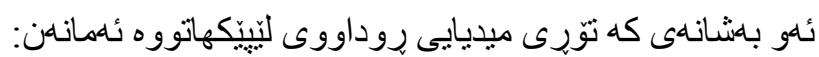

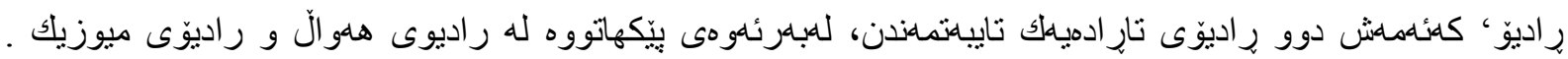

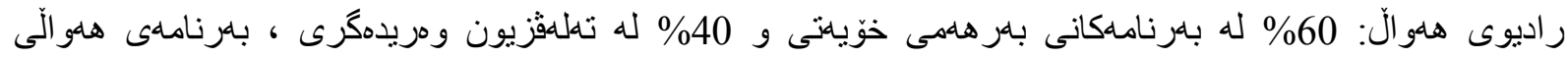

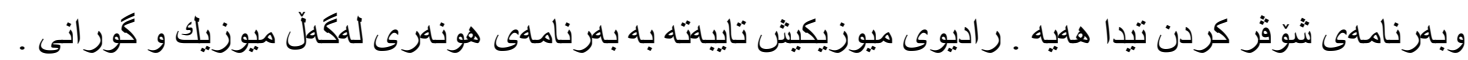

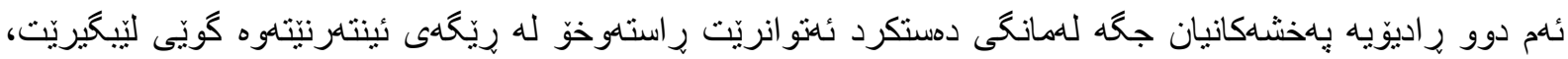

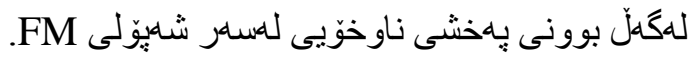

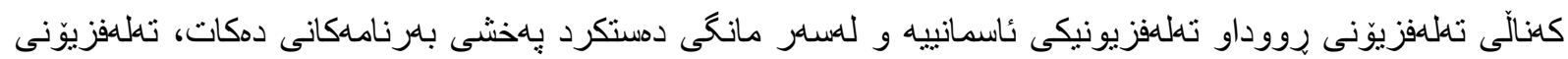

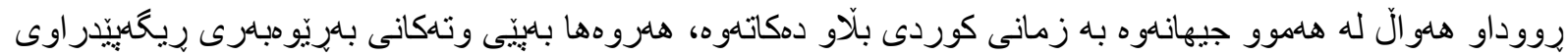

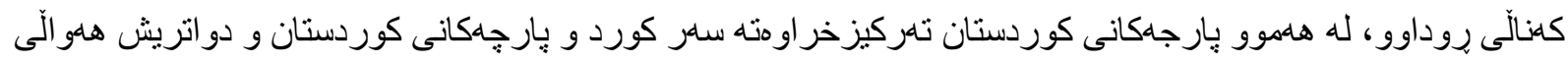

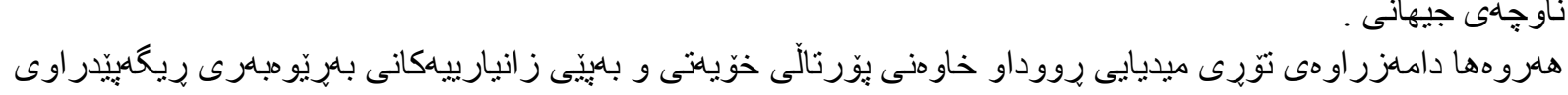

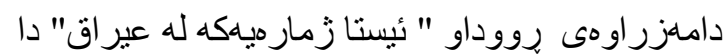

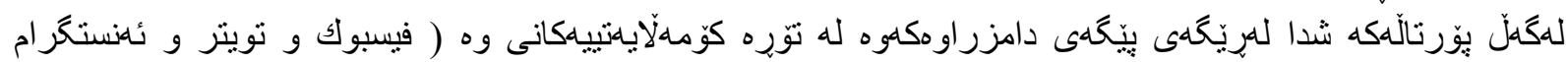

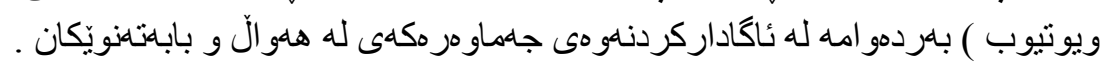

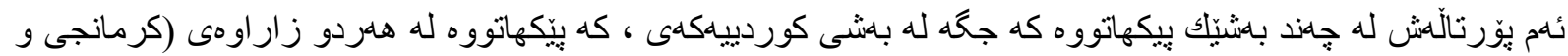

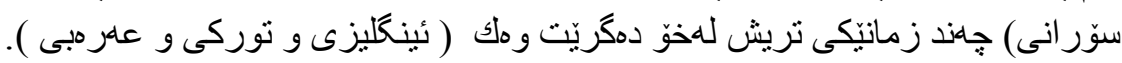

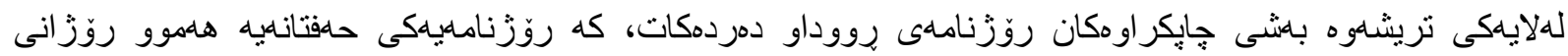

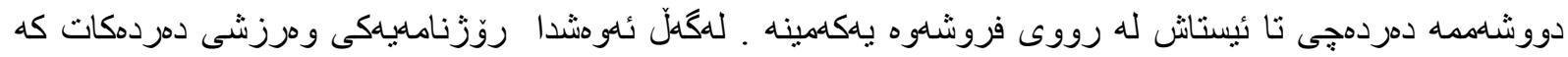

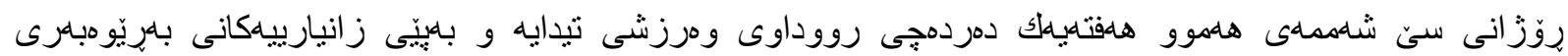

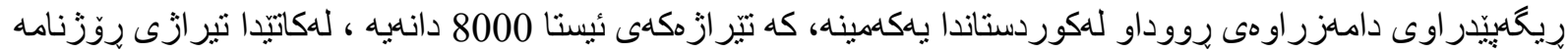

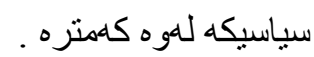

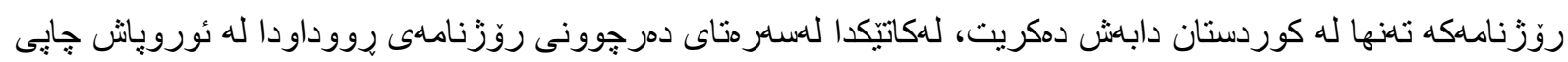

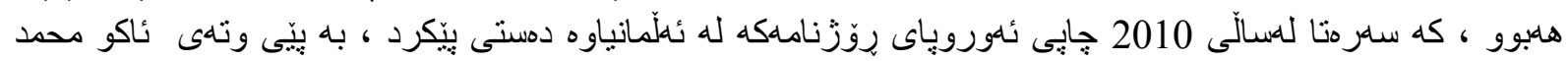

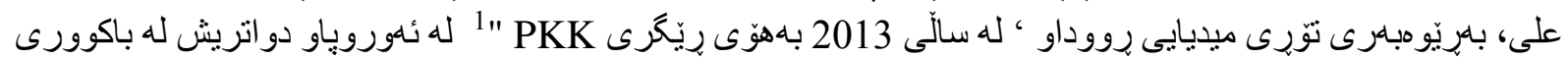

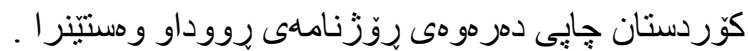

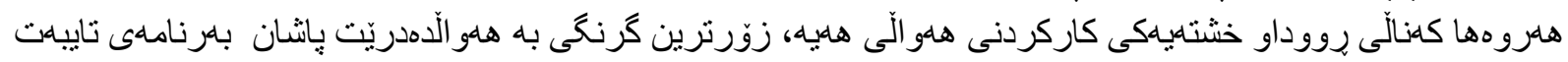

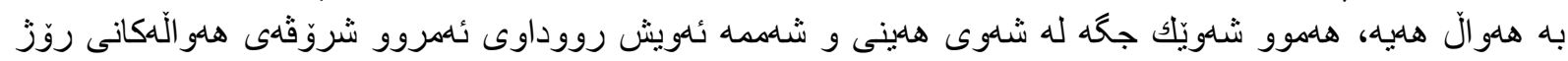

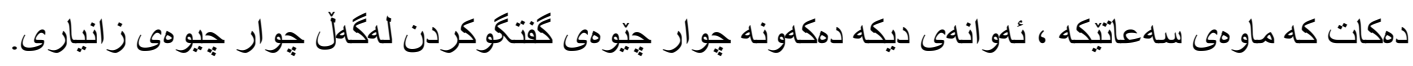




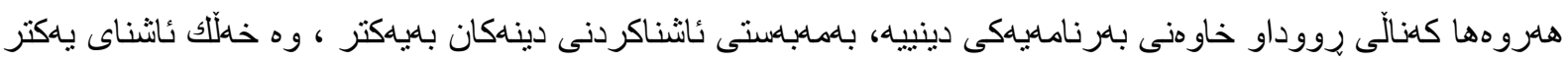

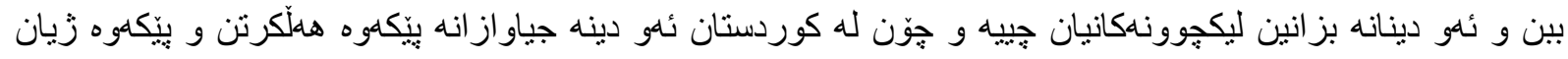

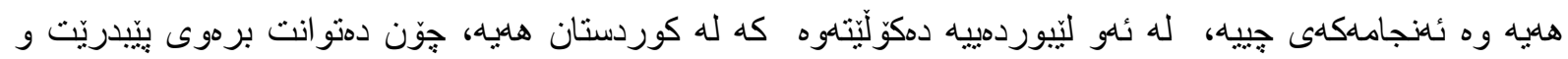

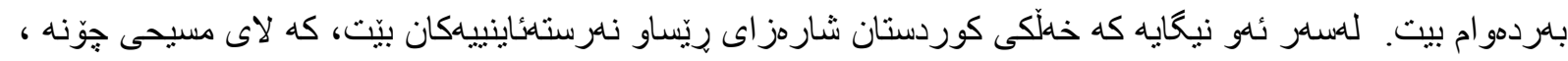

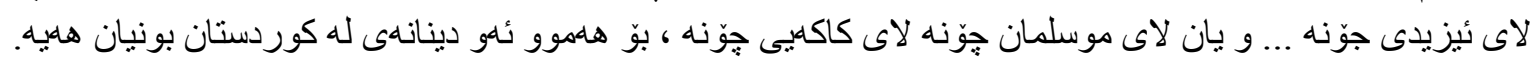

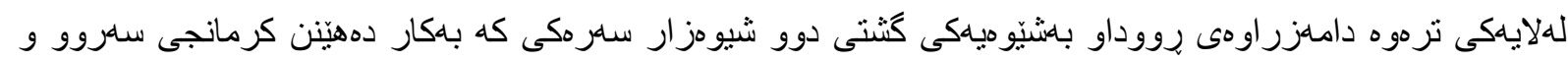

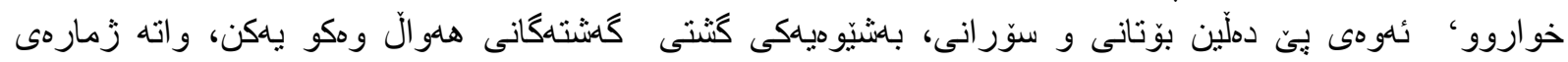

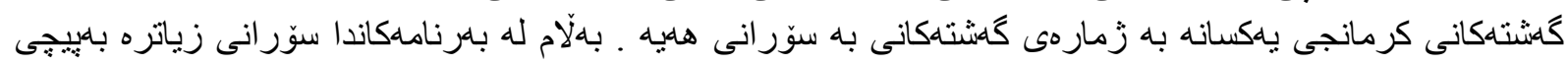

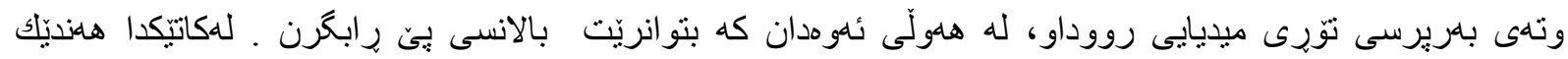

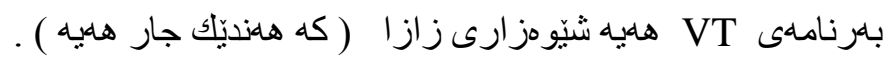

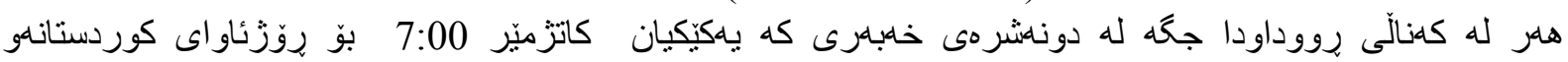

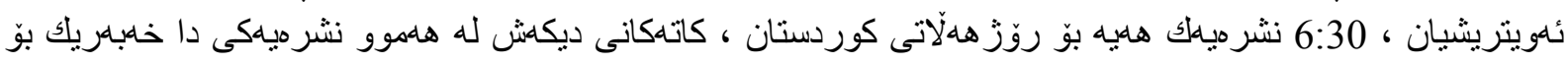

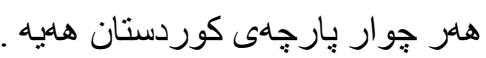

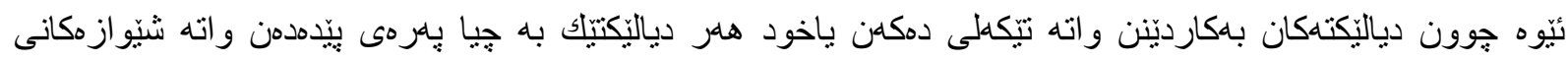

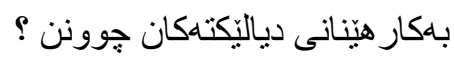

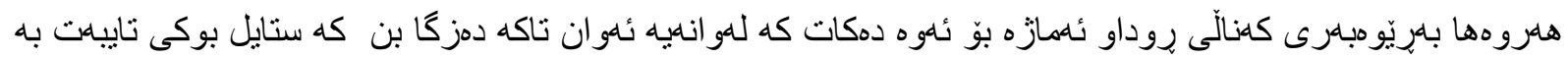

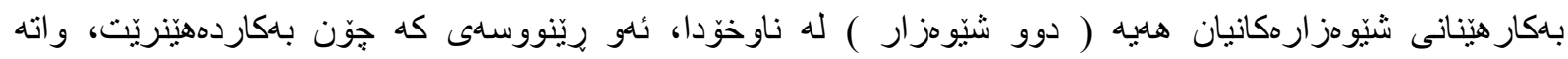

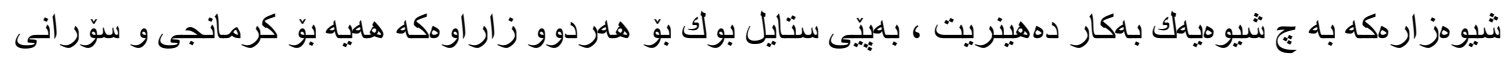

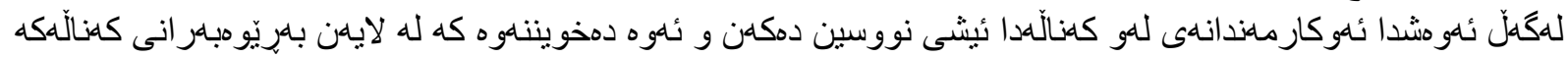

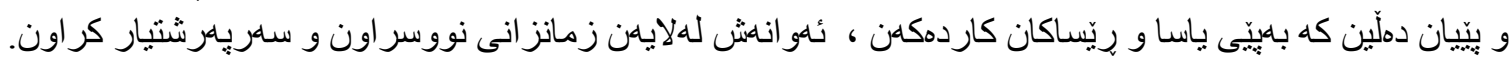

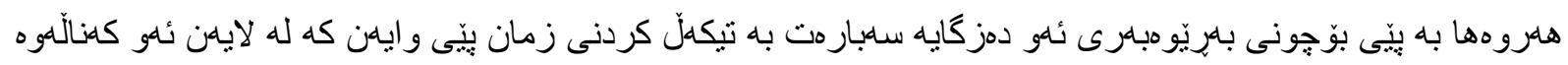

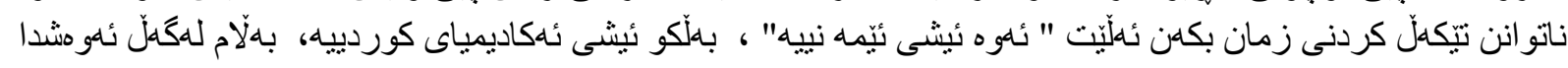

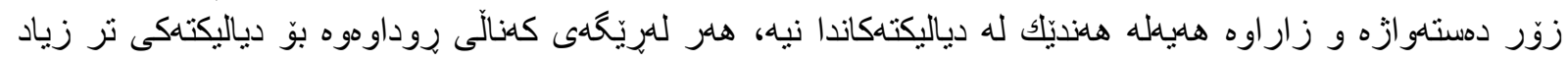

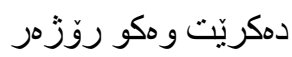

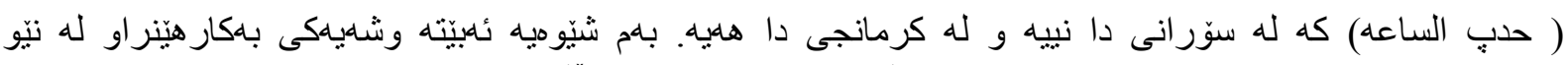

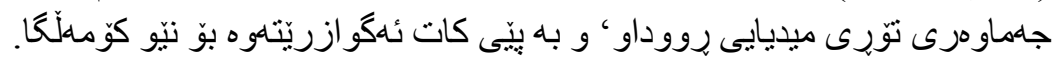

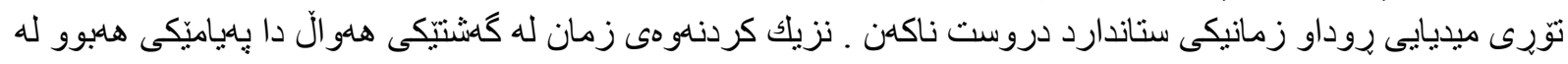

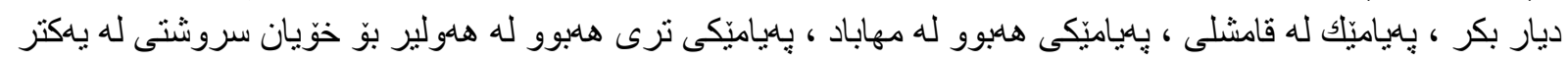

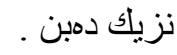
برِو انة:
دامةزرا،

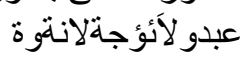

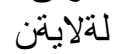 27 th 2015/5/6 http://www.pkkonline.com/en/index.php?sys=article\&artID=175

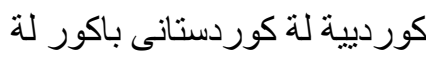

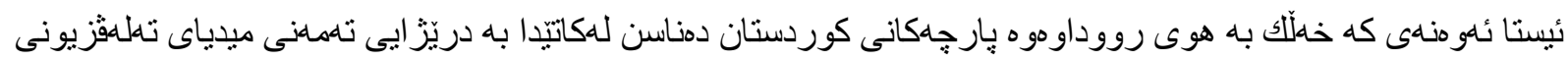

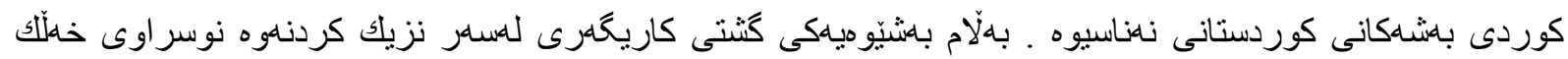

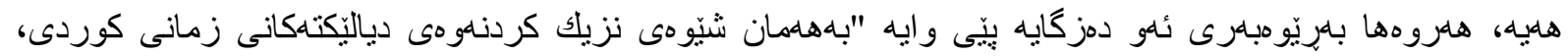

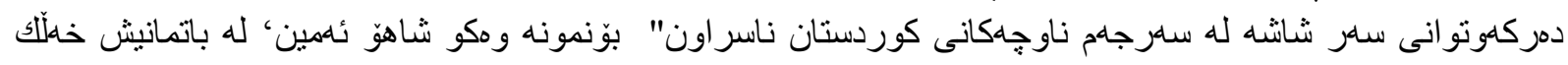




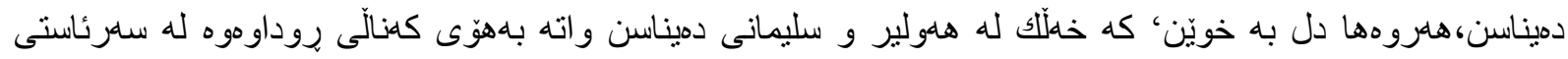

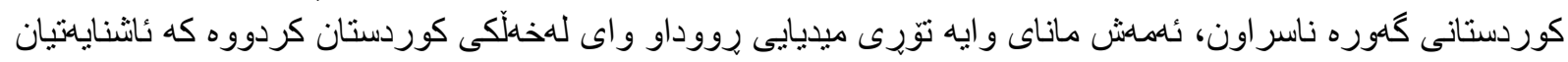

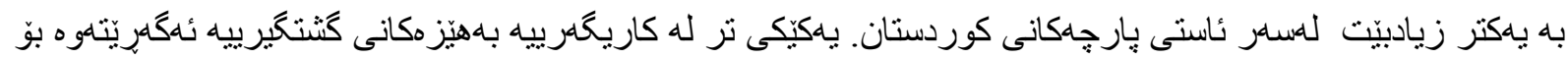

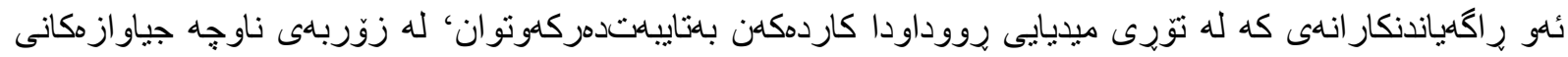

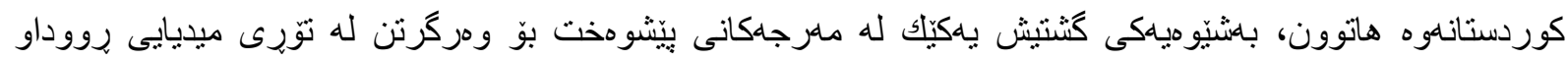

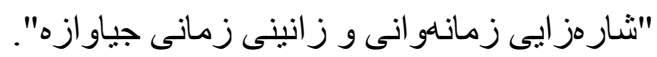

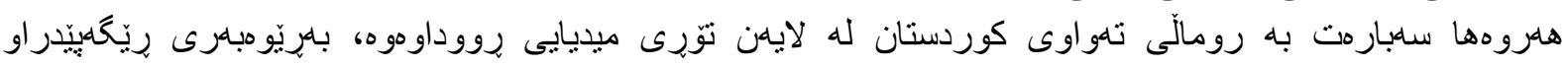

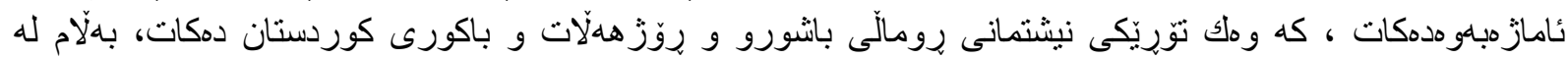

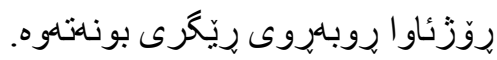

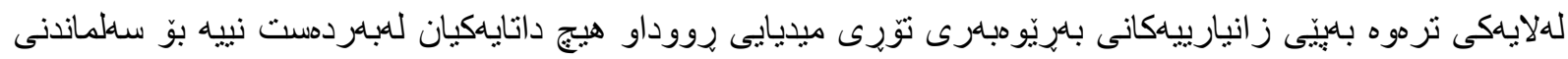

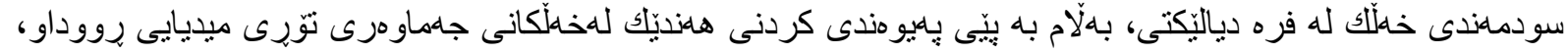

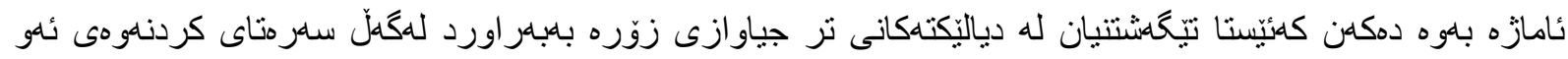

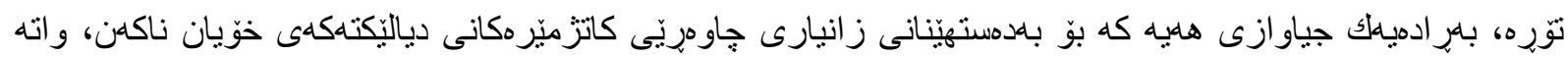

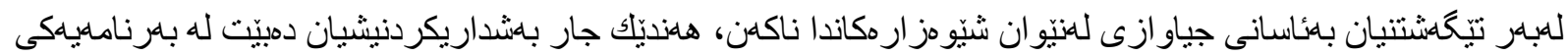

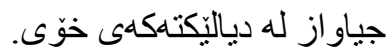

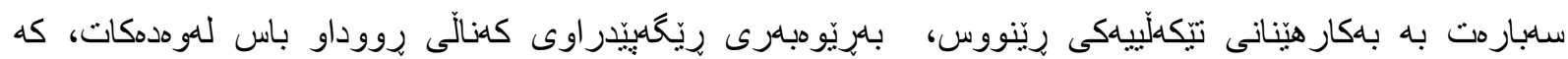

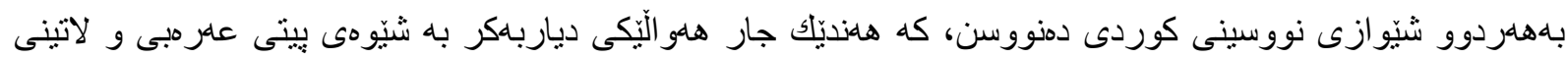

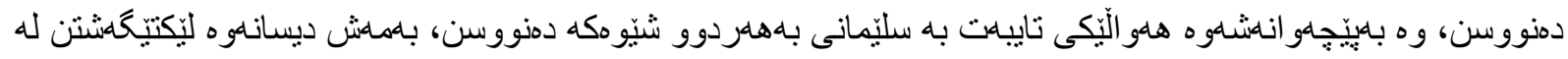

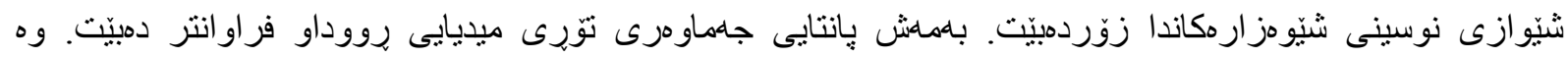

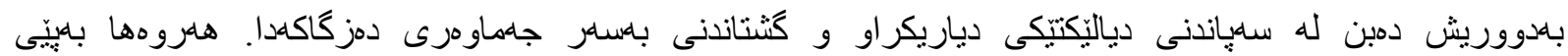

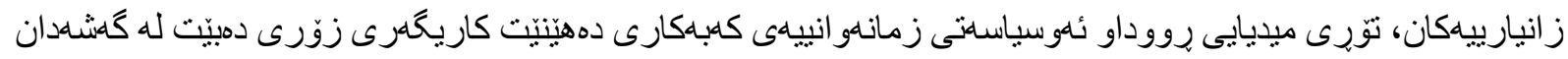

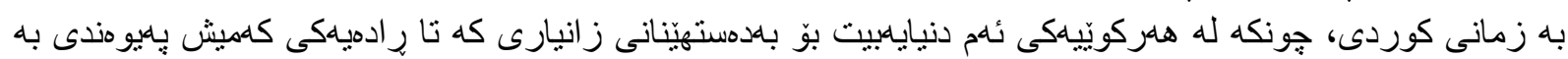

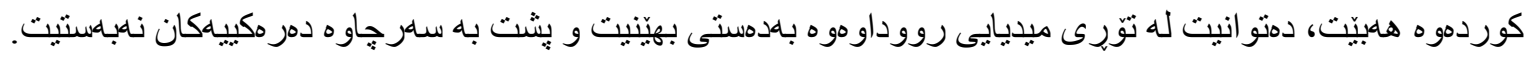

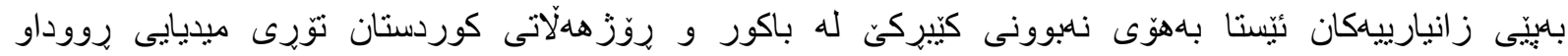

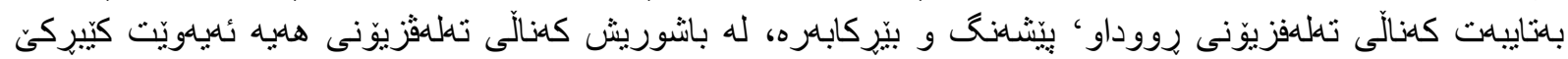

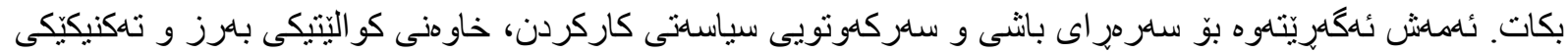

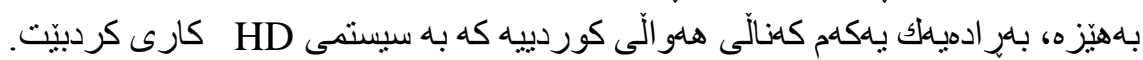

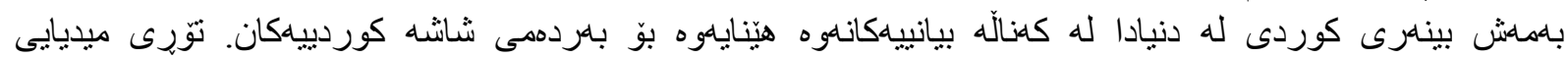

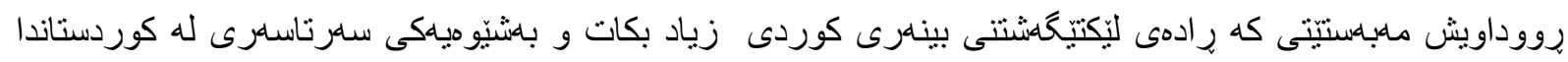

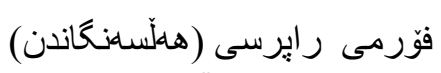

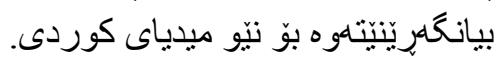

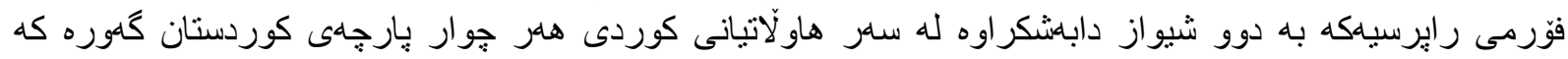

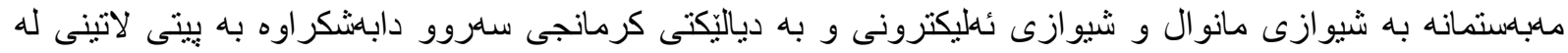

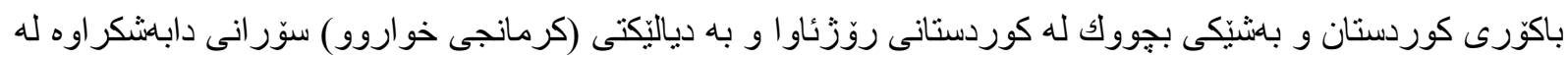

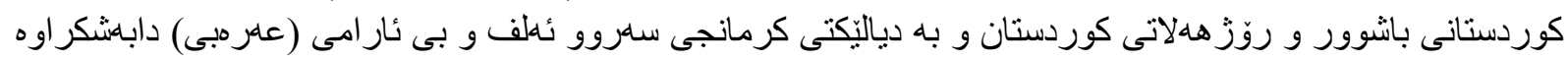

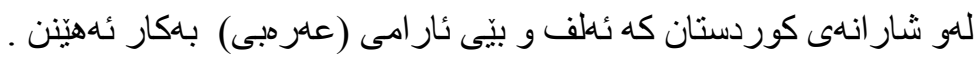

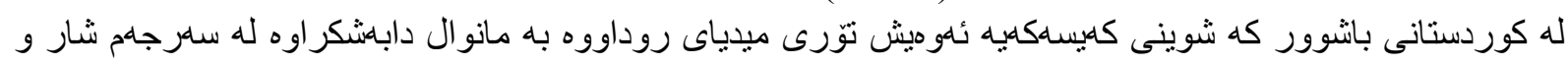

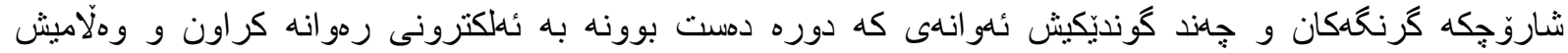

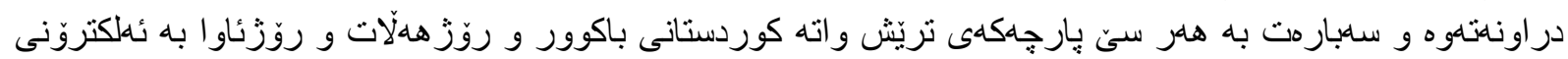

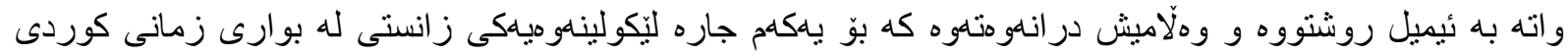

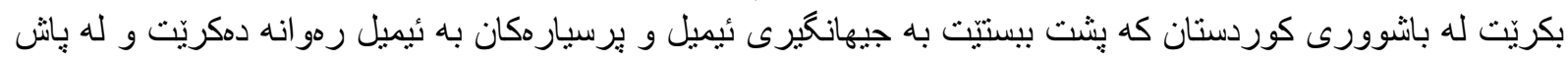

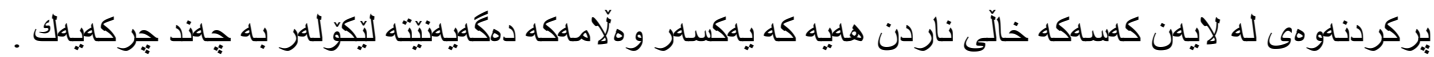

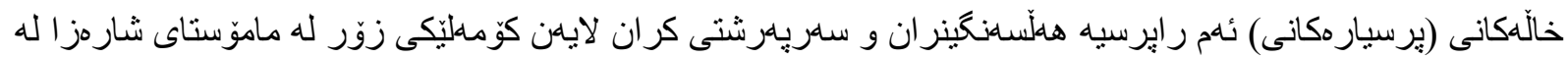

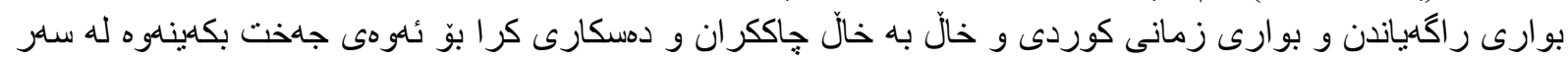




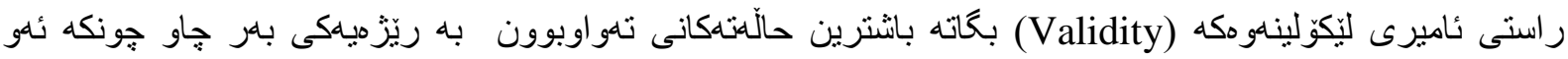

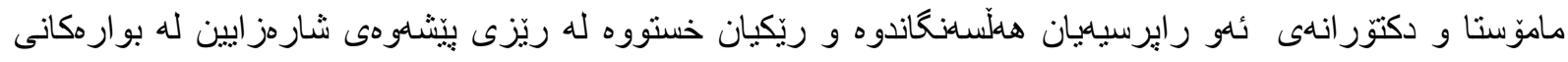

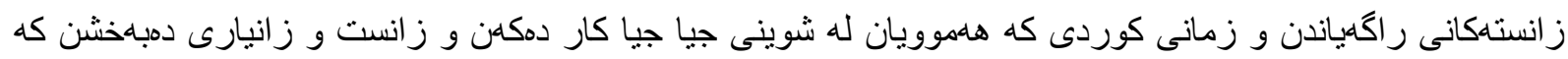

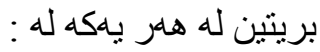

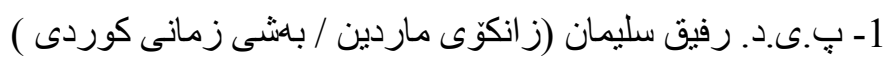

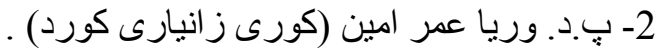

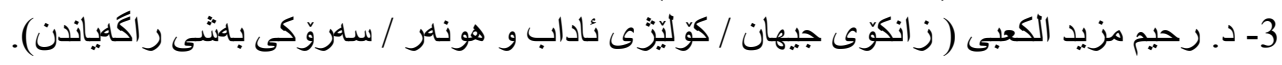

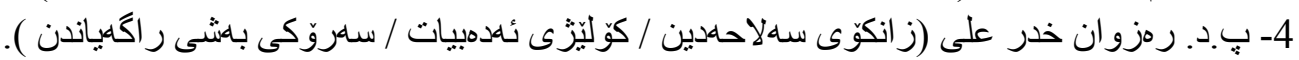

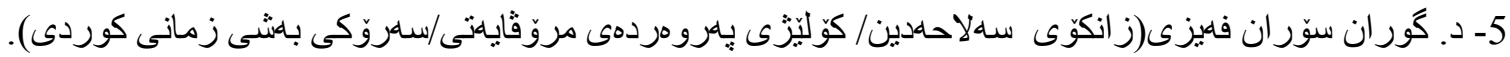

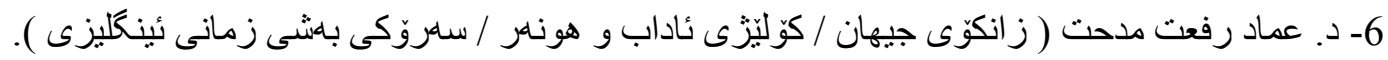

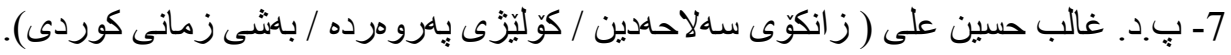

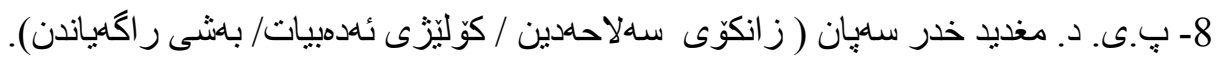

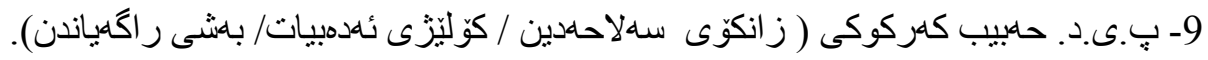

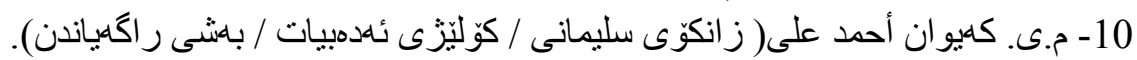

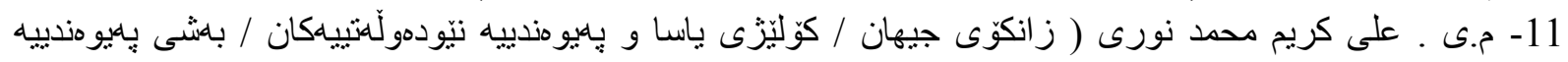

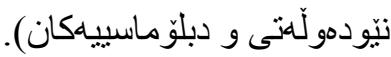

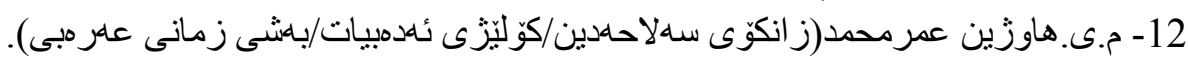

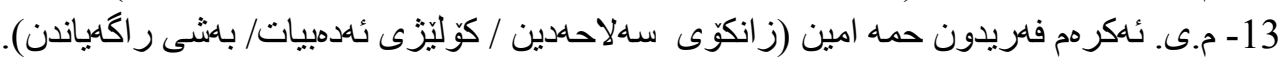

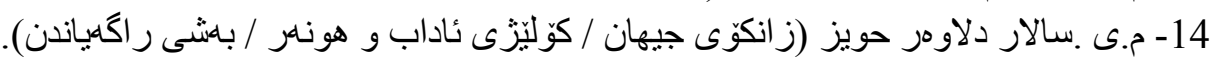

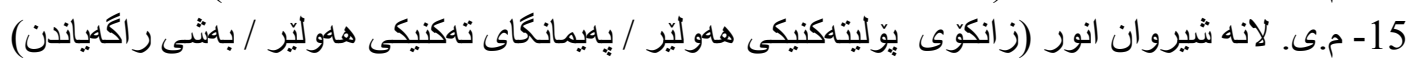

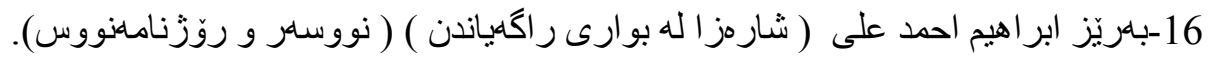

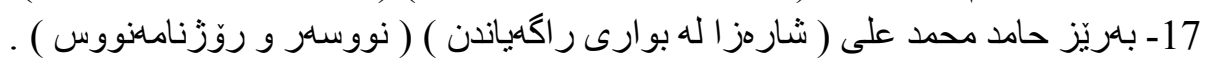

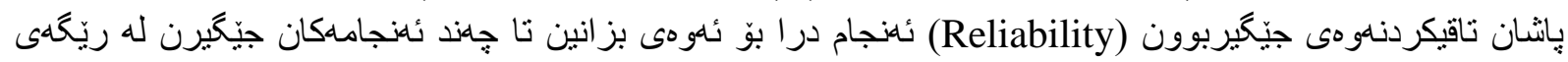

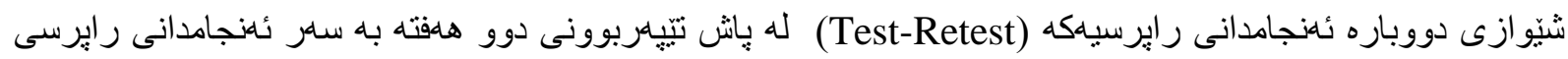

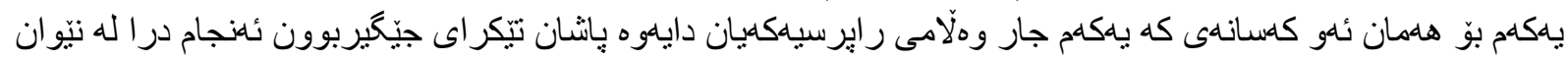

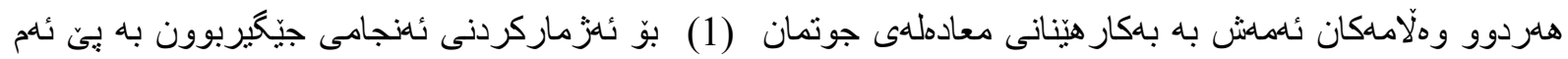

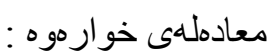

$$
\text { ن } 2 \text { أ + }
$$

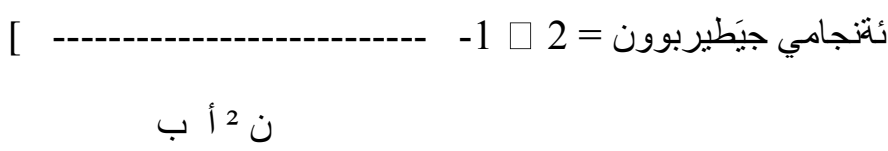

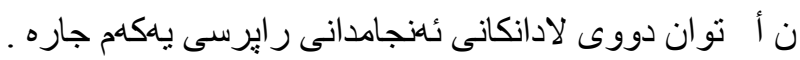

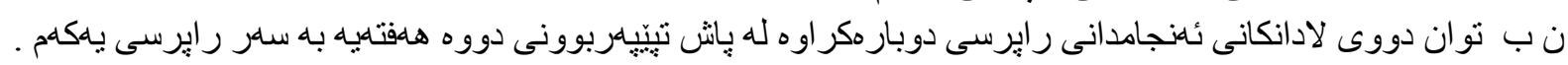

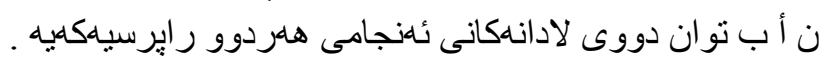

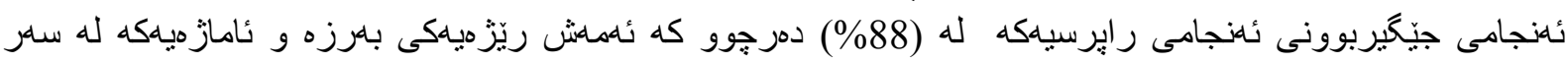

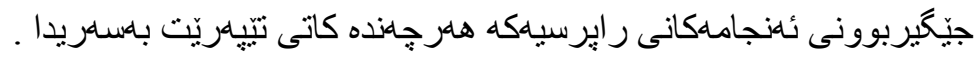

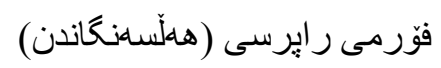

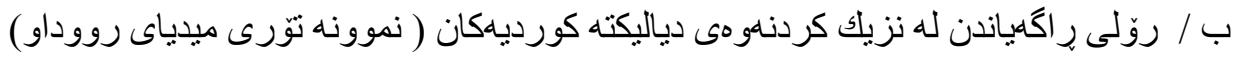

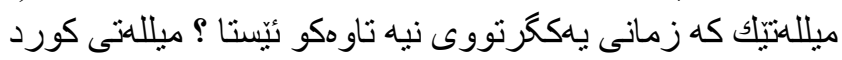

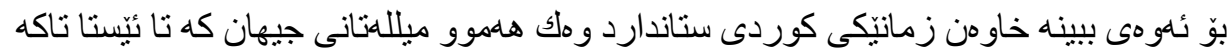

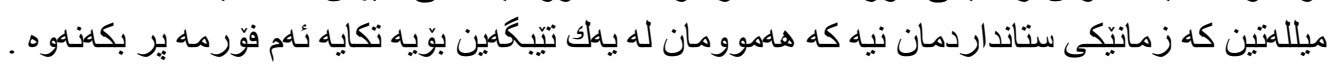




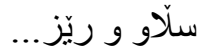

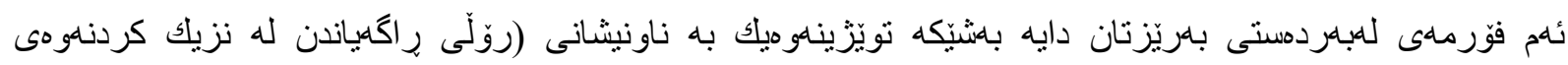

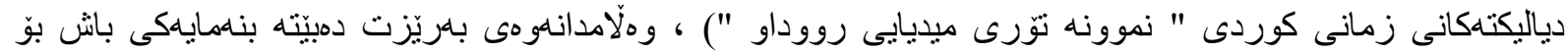

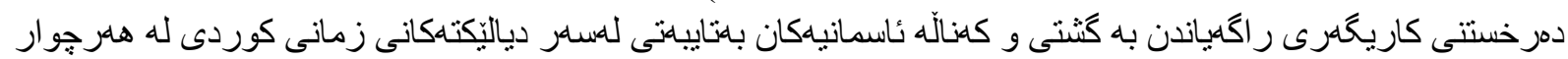

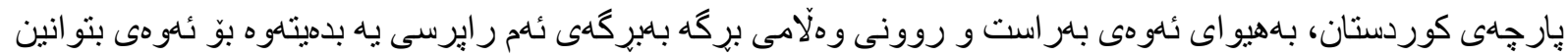

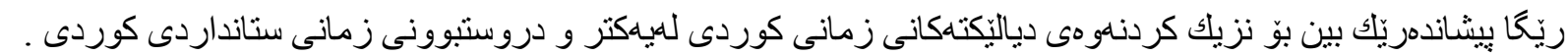

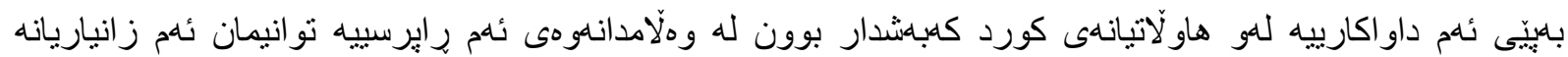

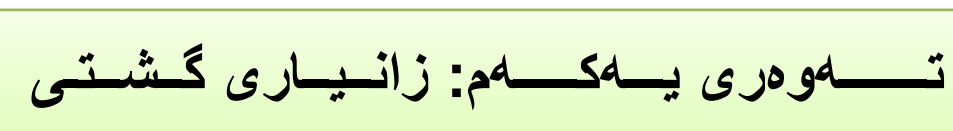

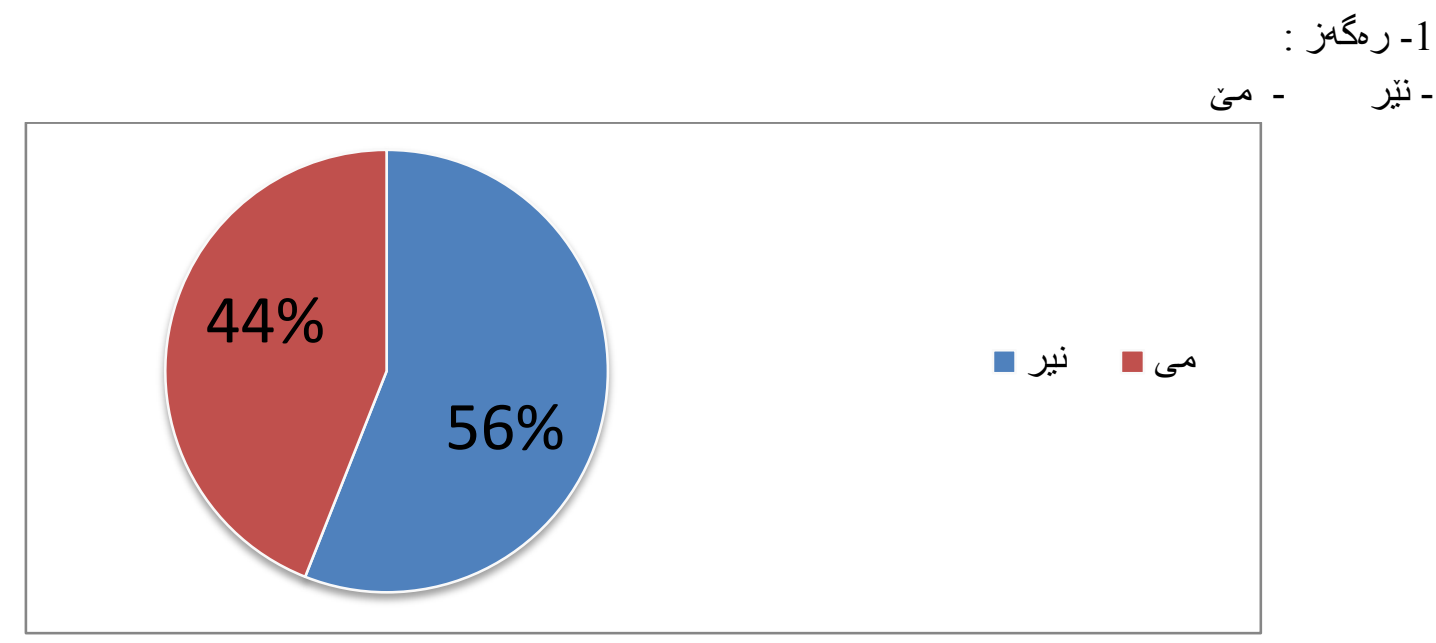

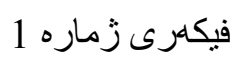

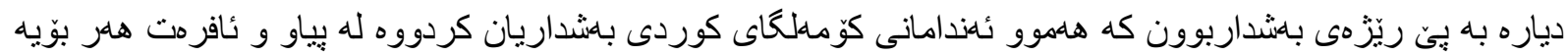

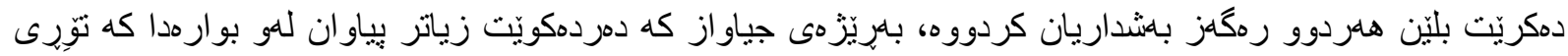

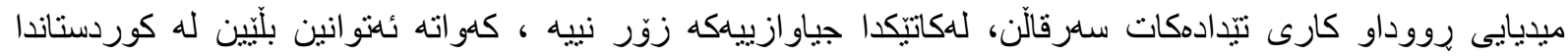

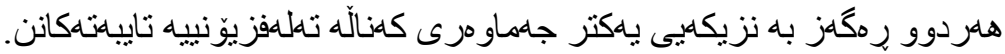

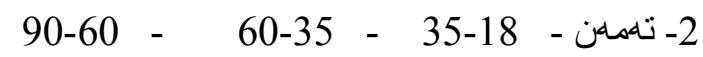

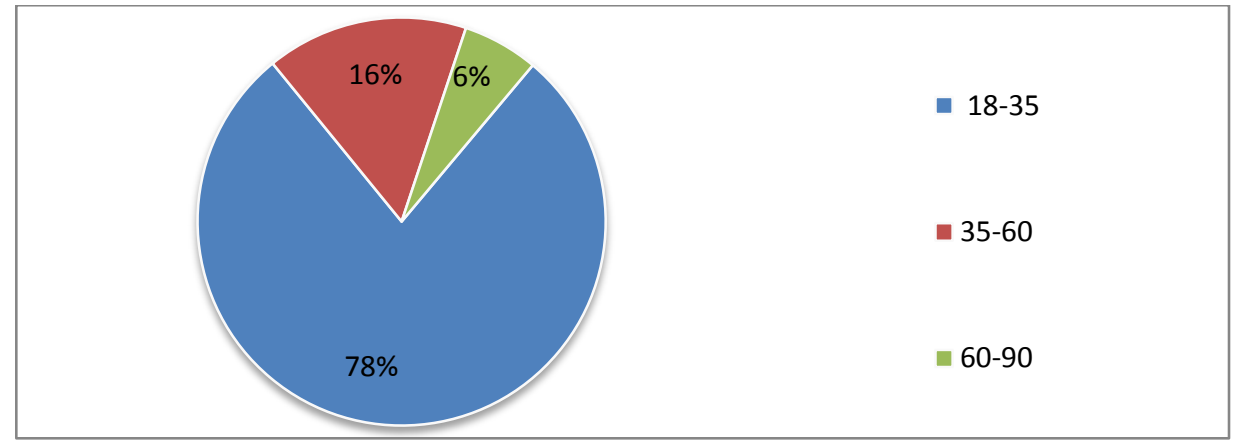

فيكارى زماره

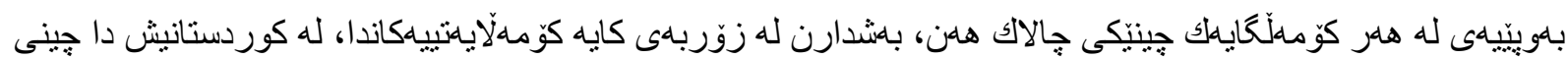

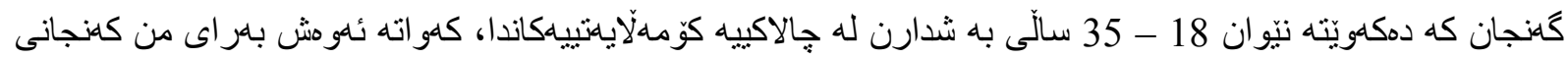

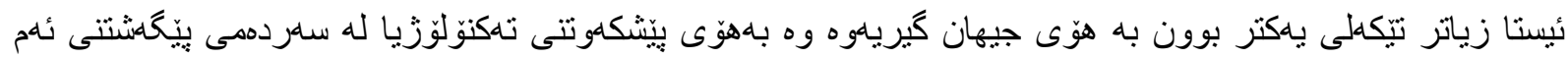

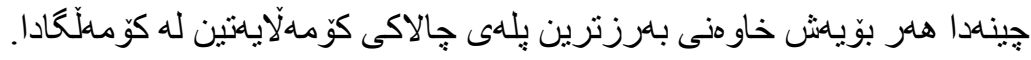
3 - ئاستى خويَندن 

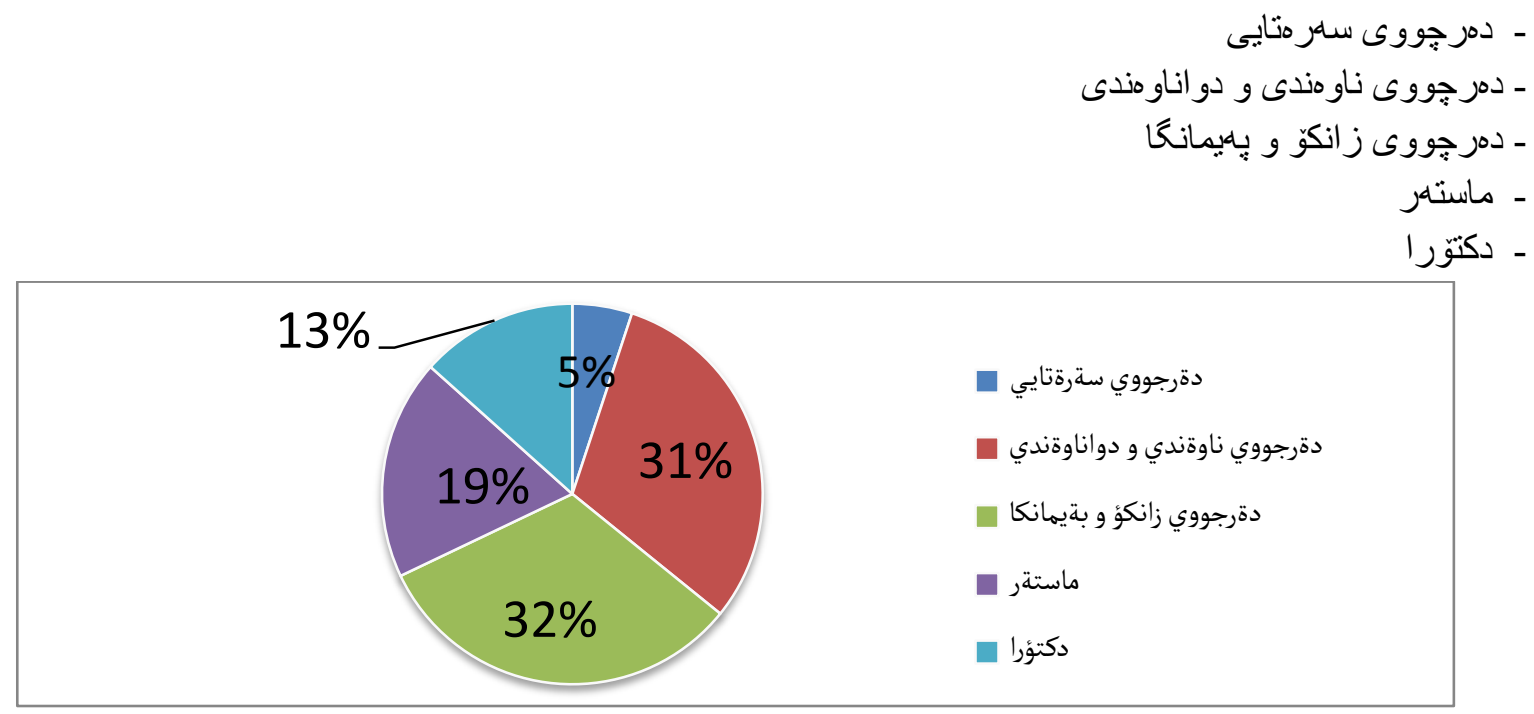

فيكهرى زماره 3

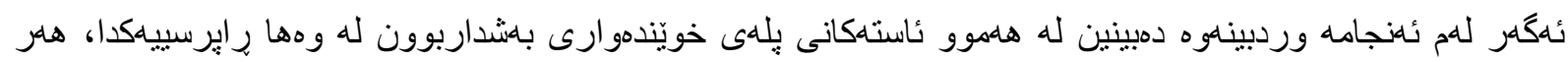

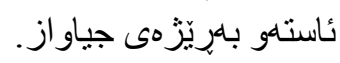

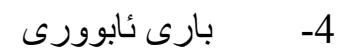

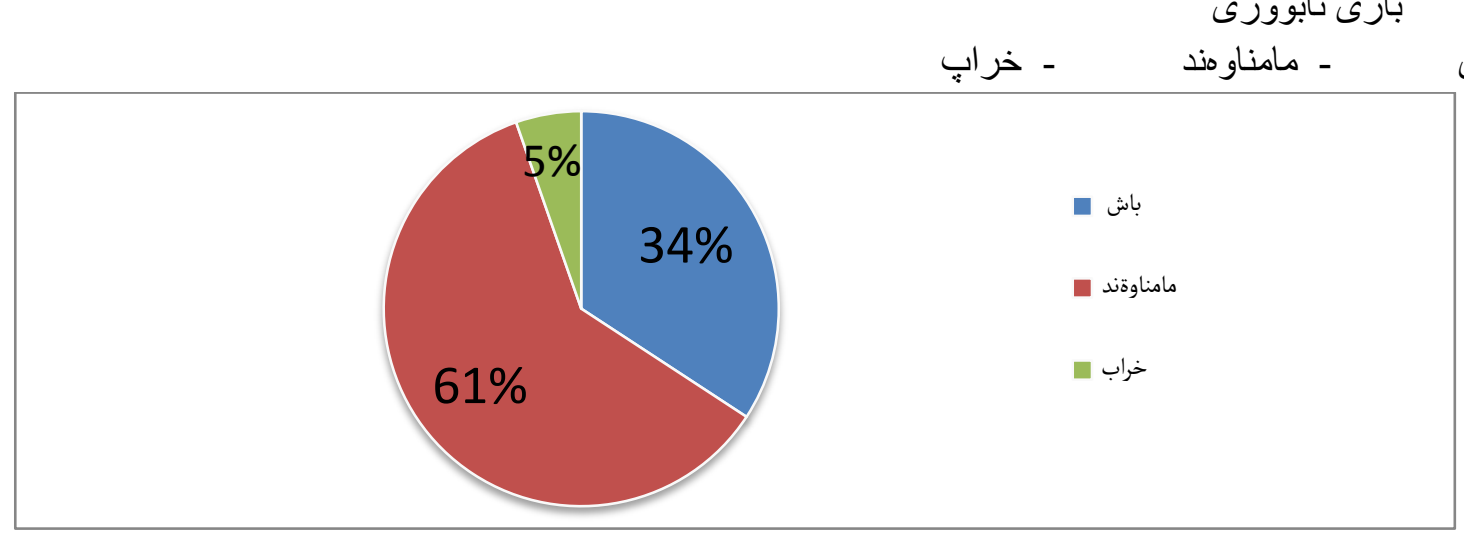

فيكهرى زماره

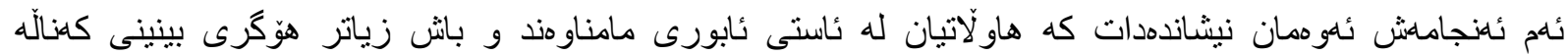

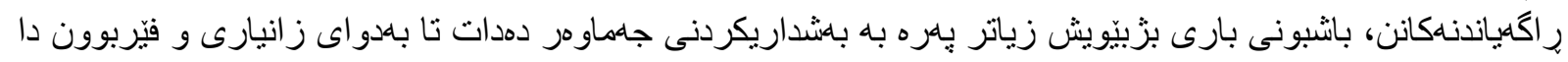

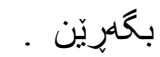
5- بيشئ - كارى كئز اد - كاد

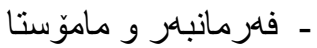
-

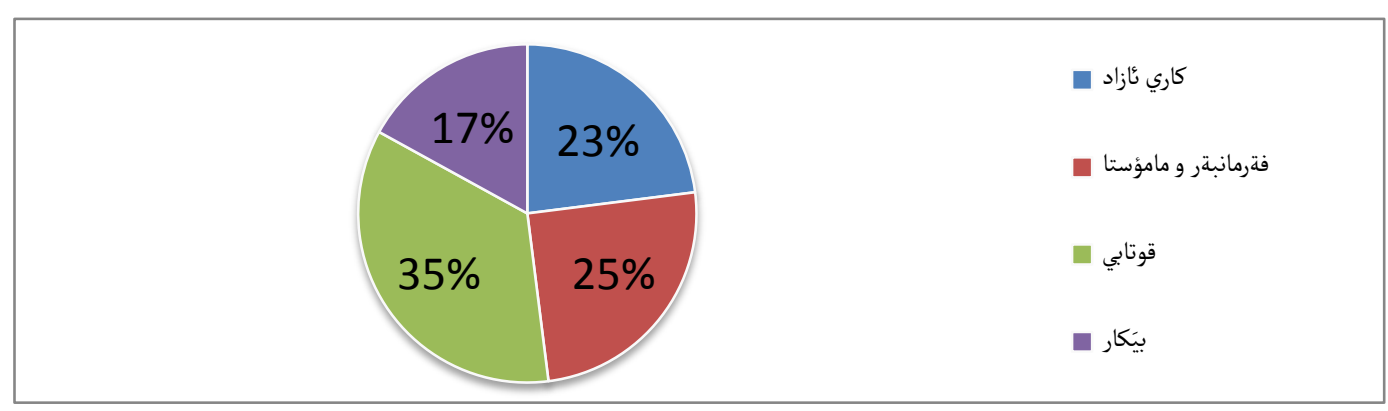

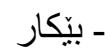




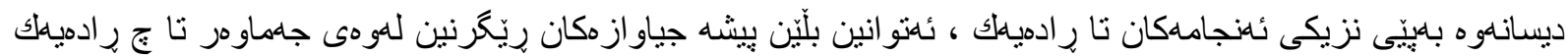

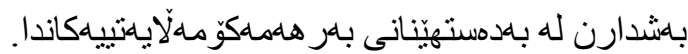

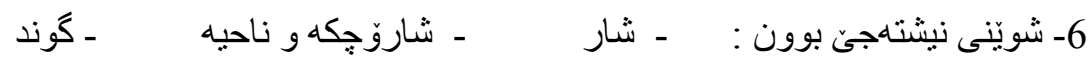

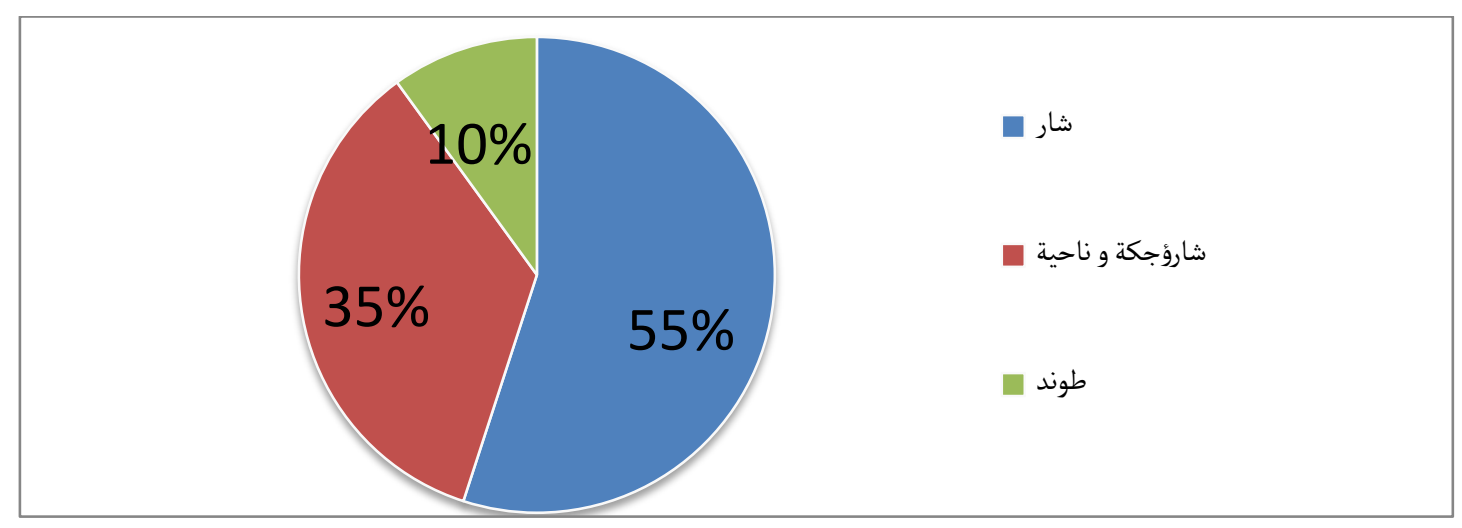

فيكهرى زماره

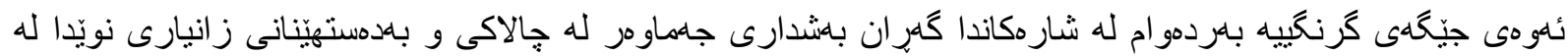

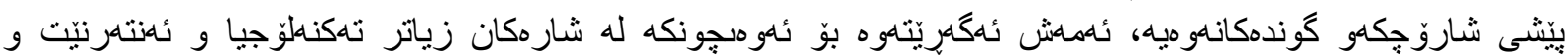

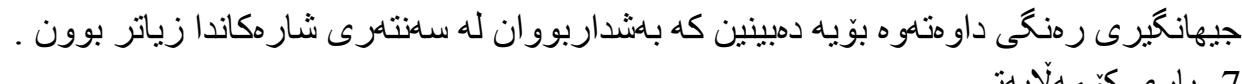

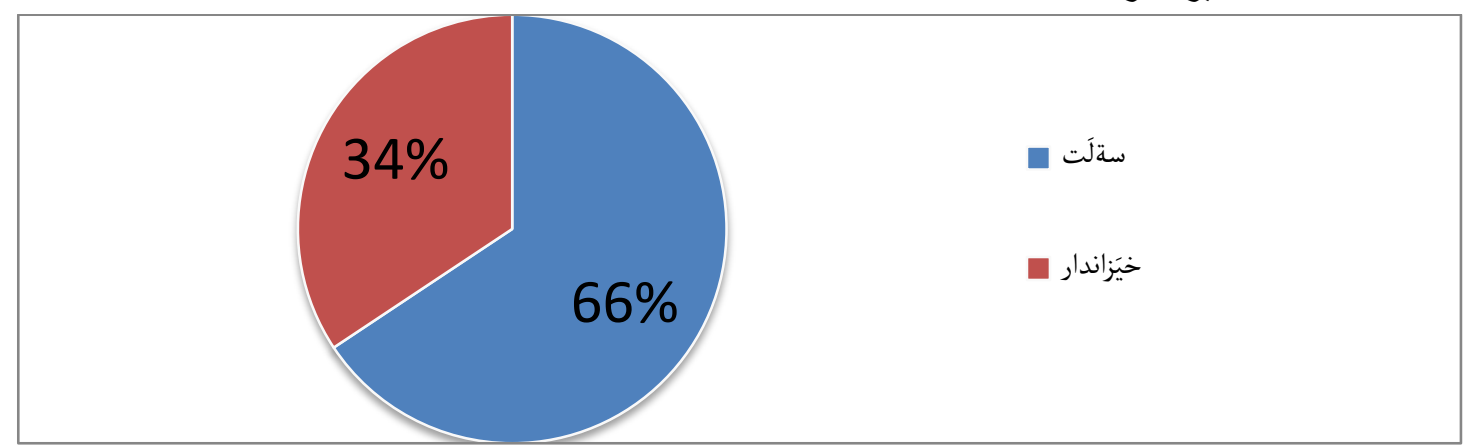

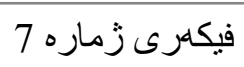

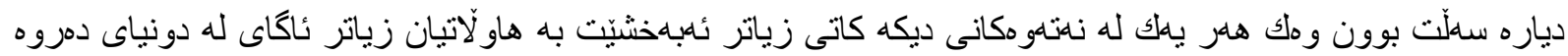

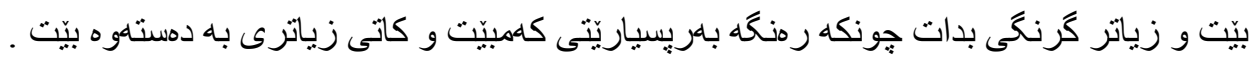

\section{تهوهرى دووهر:. كاريكهرى راگهياندن لهسهر دياليّكتهكانى}

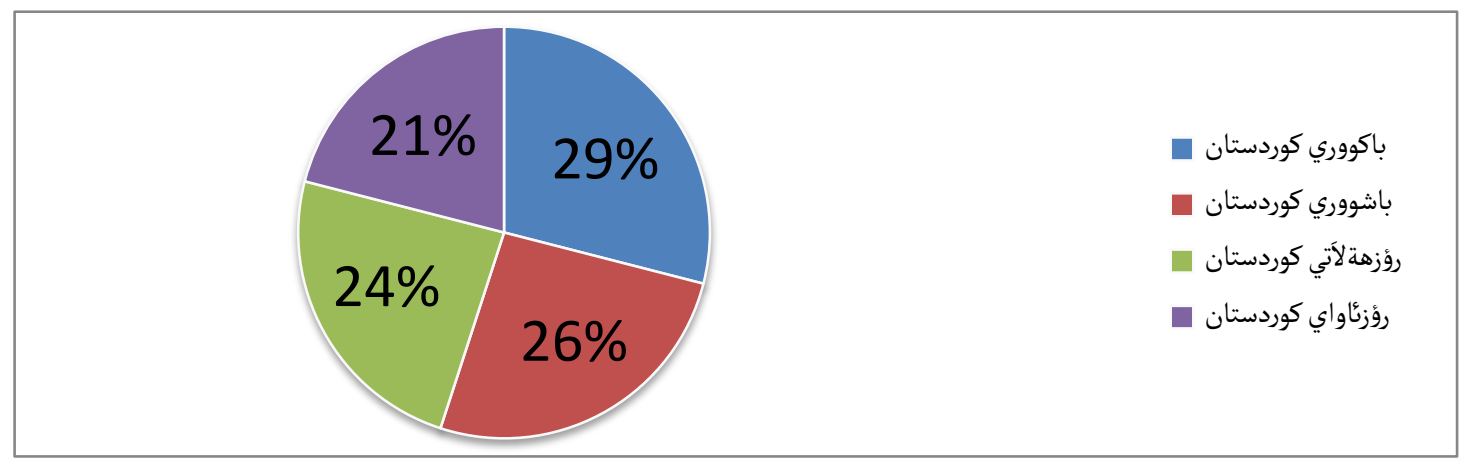

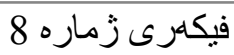

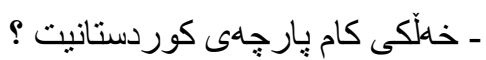




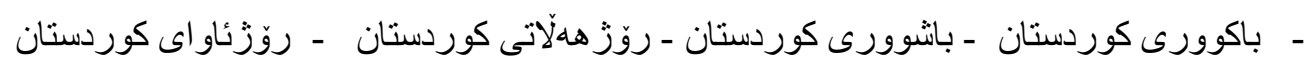

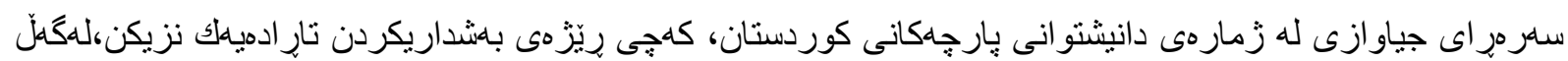

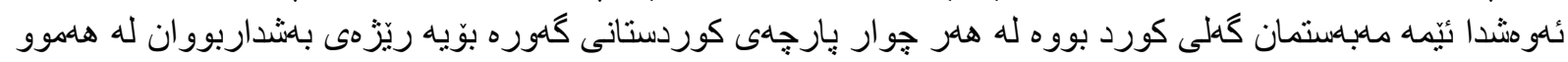

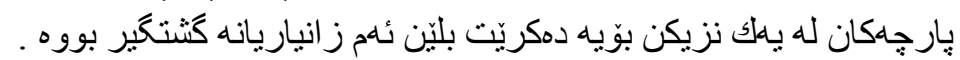

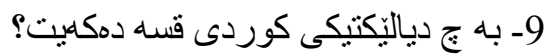

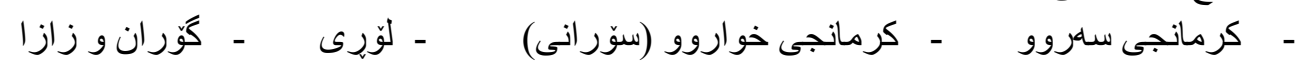

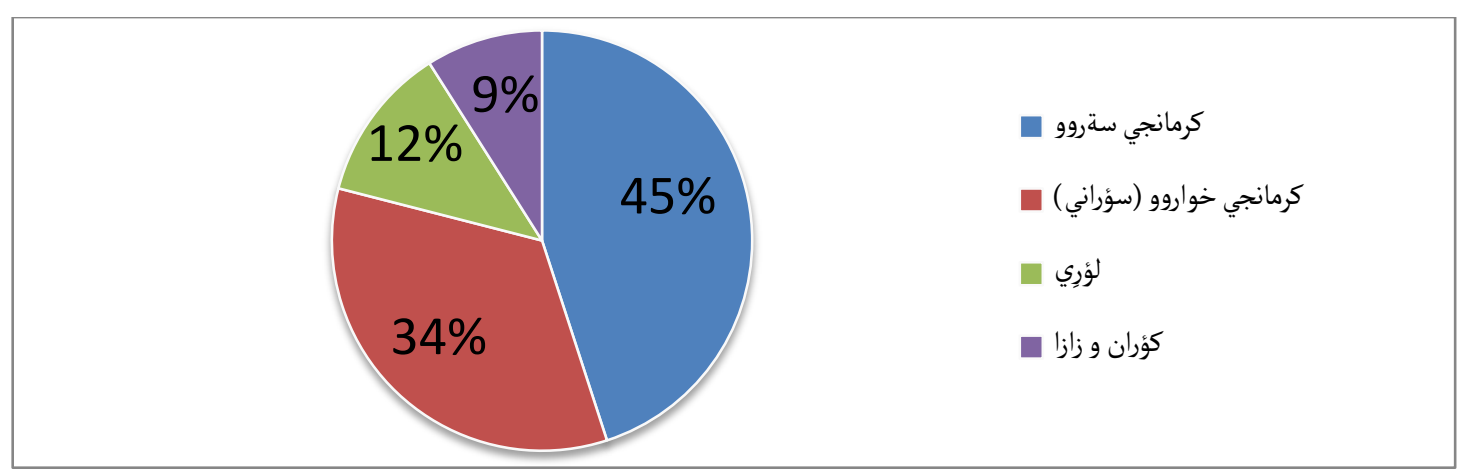

$$
\text { فيكهرى زماره } 9
$$

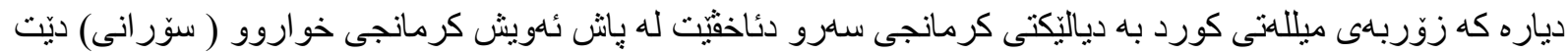

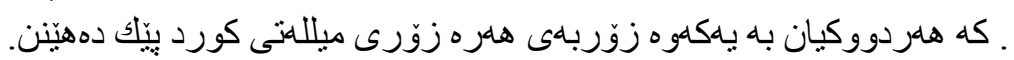

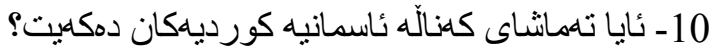

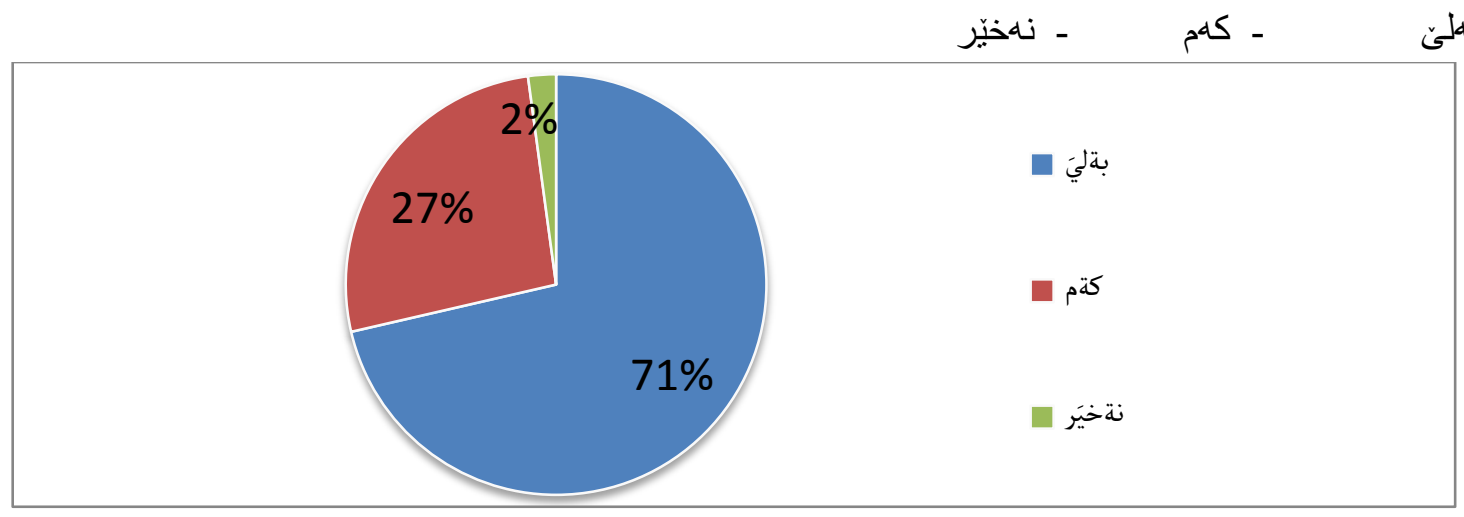

$$
\text { فيكمرى زماره } 10
$$

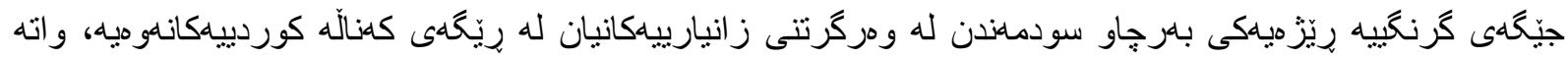

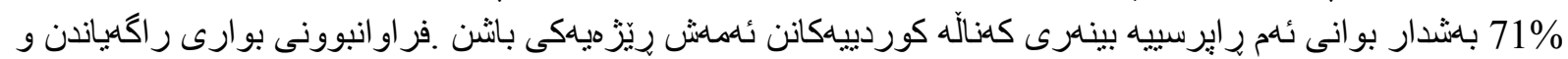

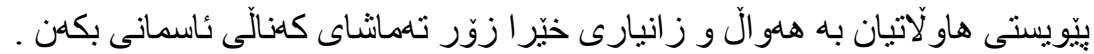

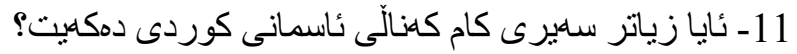

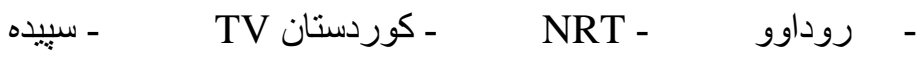

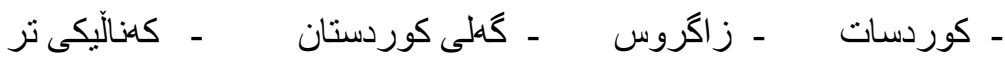




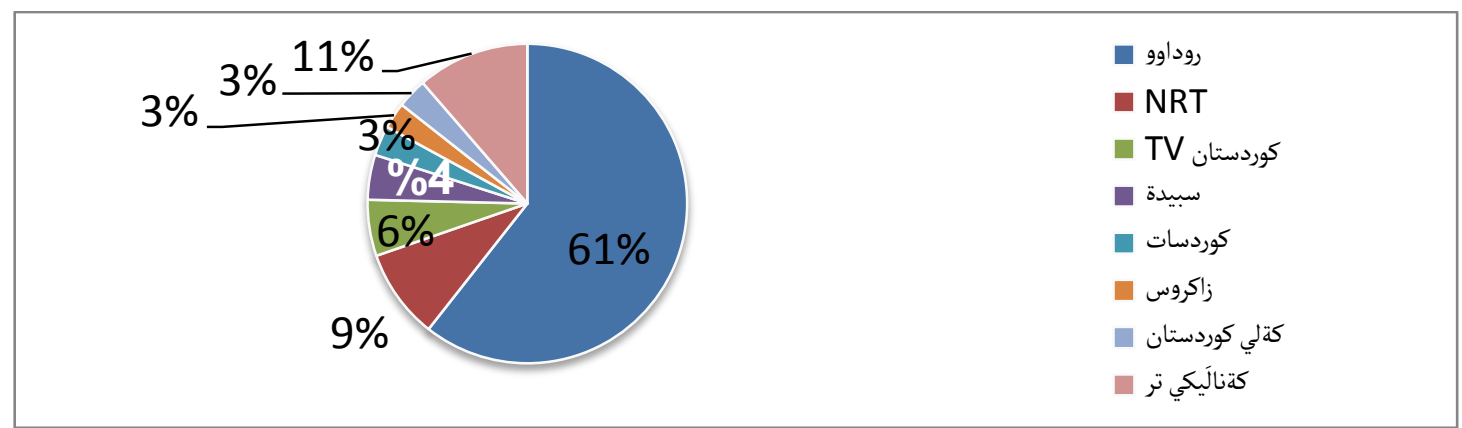

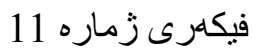

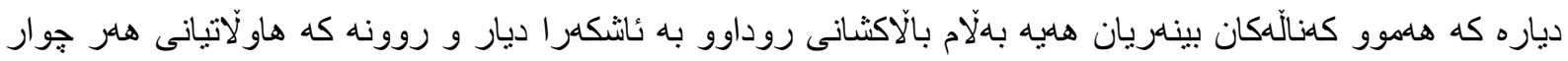

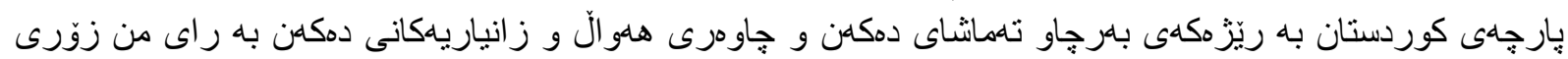

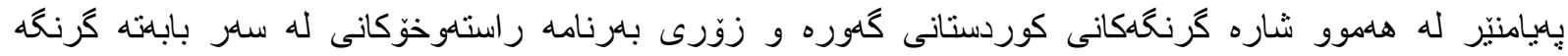

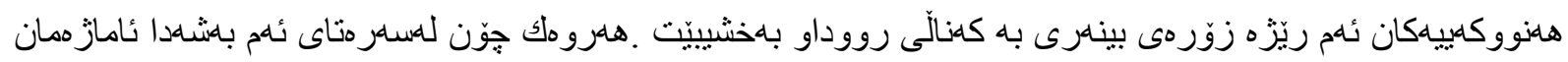

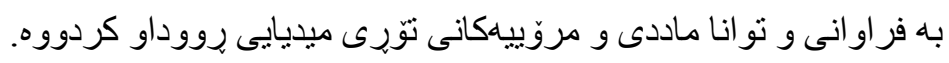

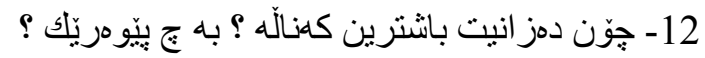

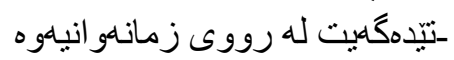

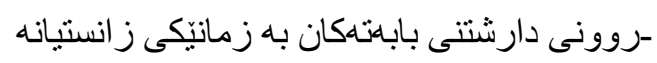

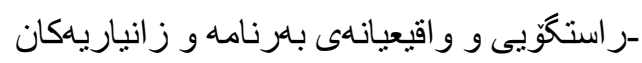

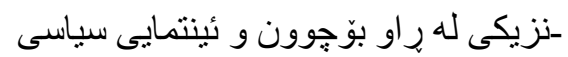

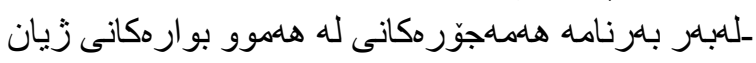
-بوّ زانينى رووداوهكانى جيهان

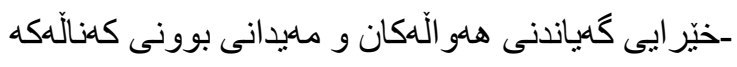

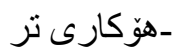

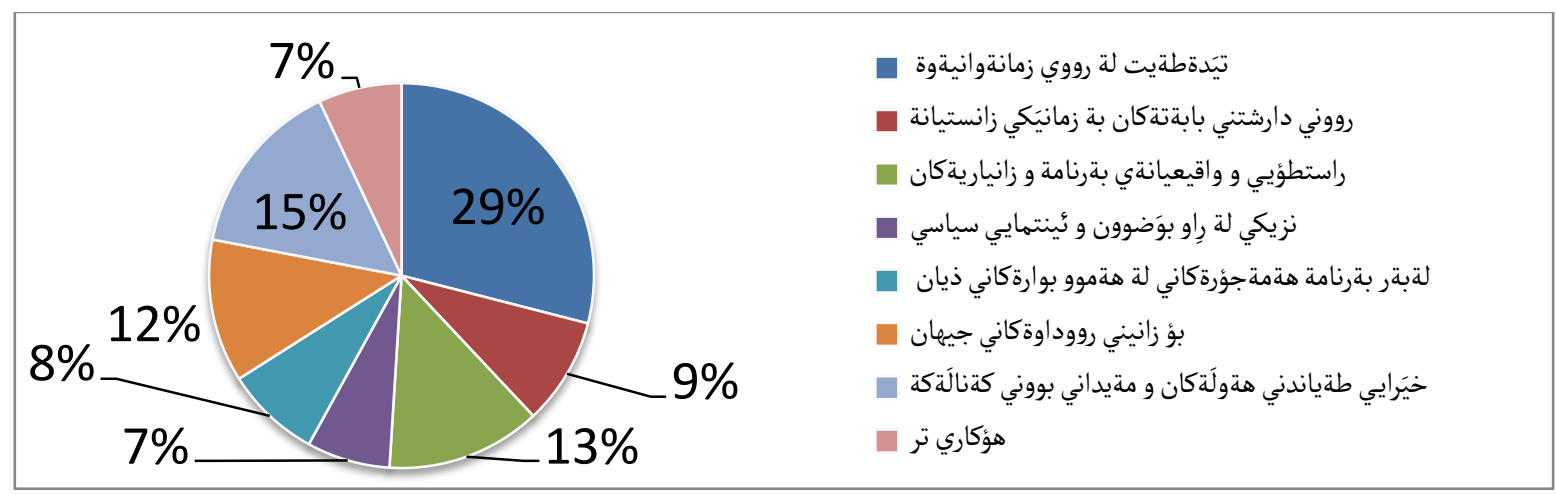

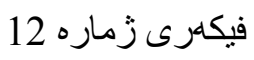

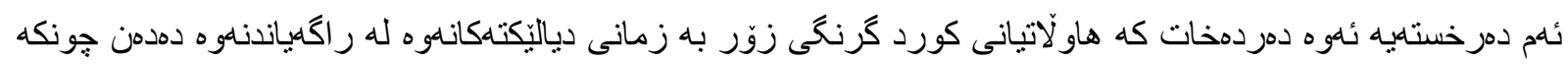

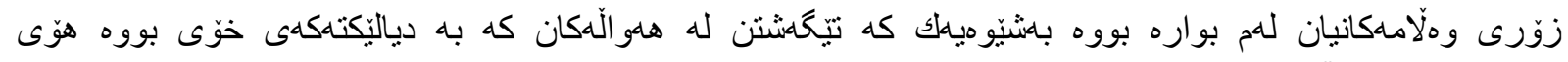

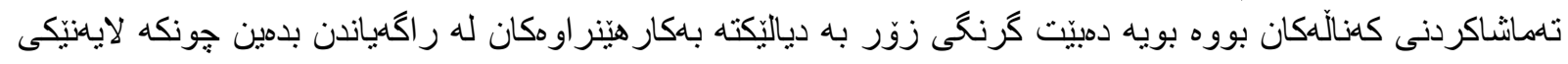

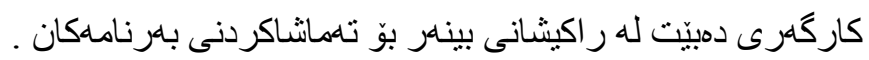

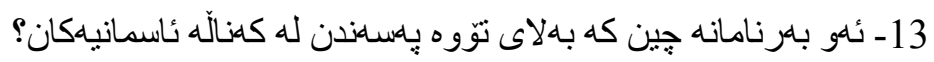

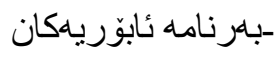

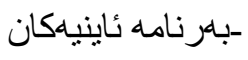
-بارنامه تاهندروستيهكان -

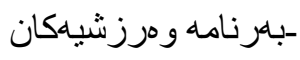

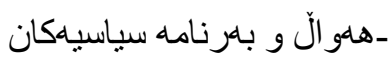

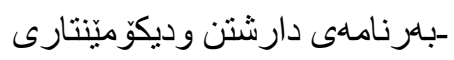




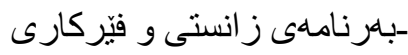

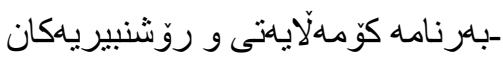

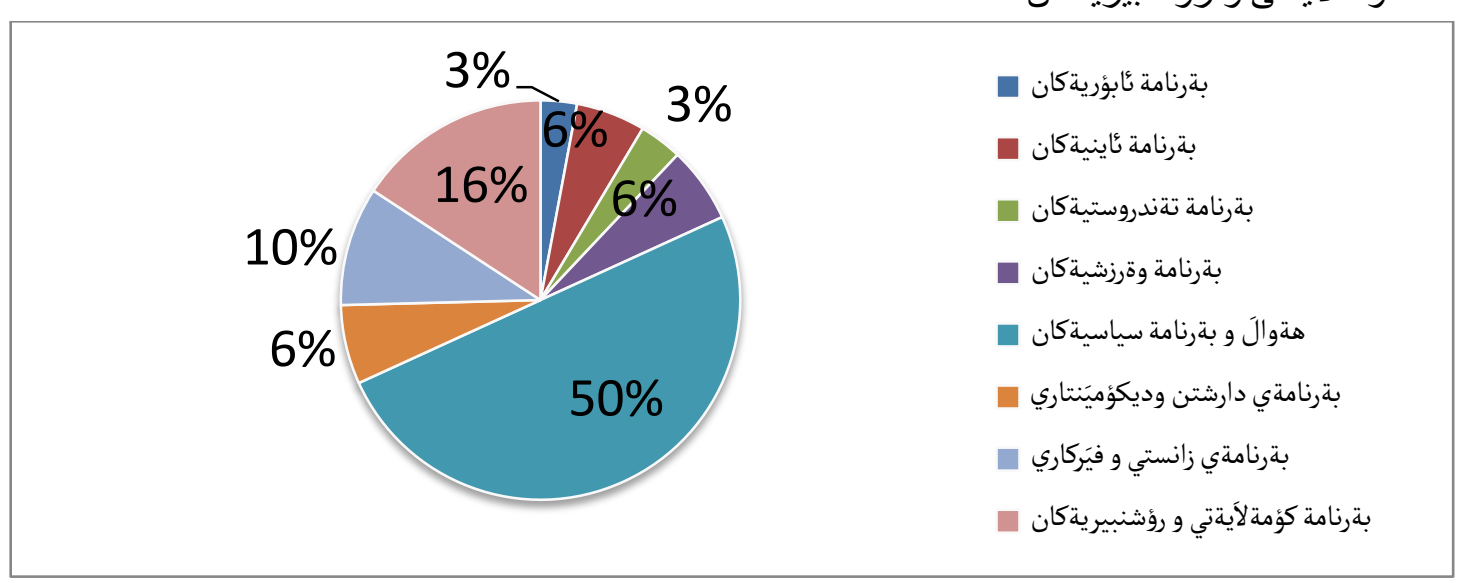

فيكمرى زماره 13

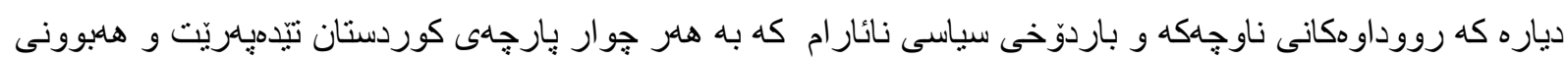

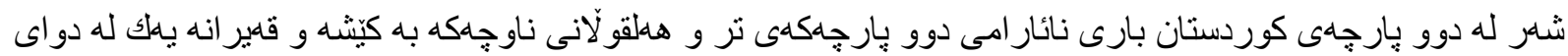

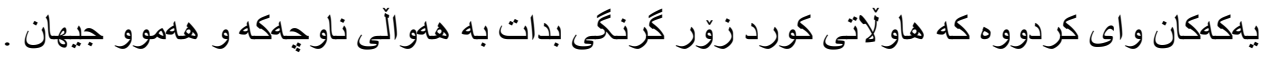

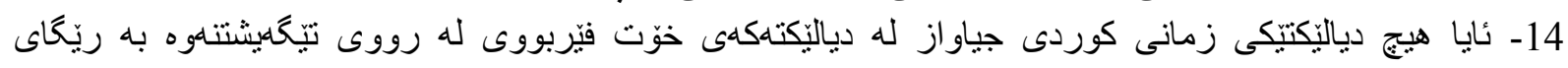
راكمياندناوه

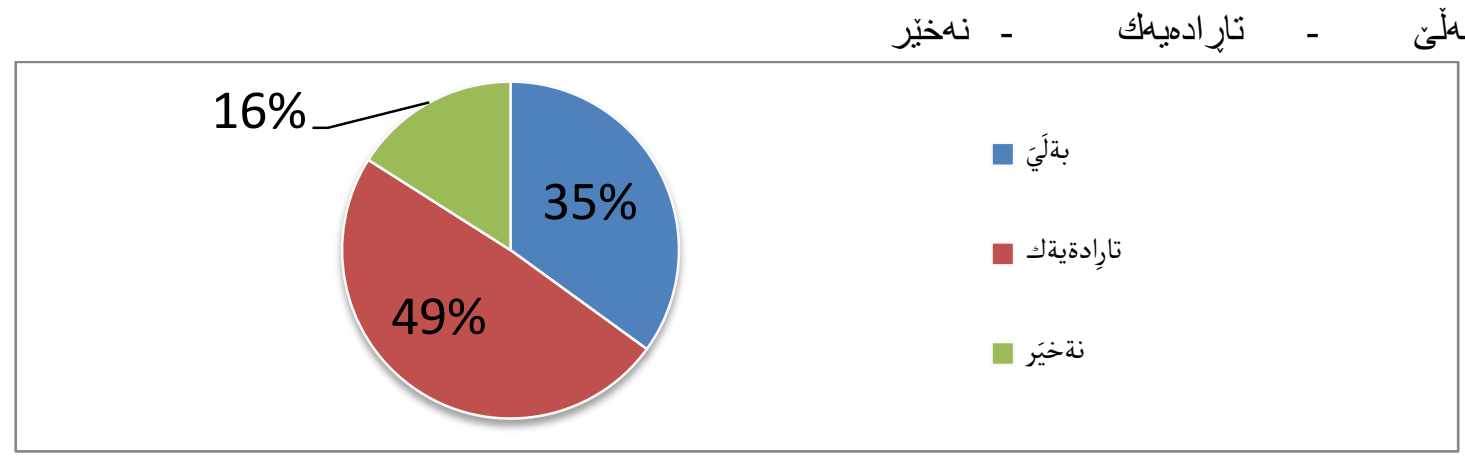

فيكهرى زماره 14

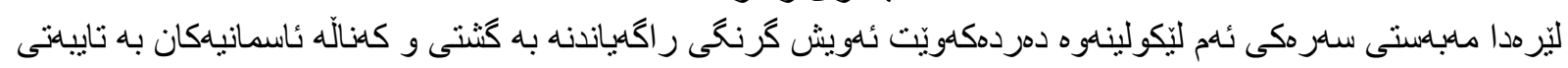

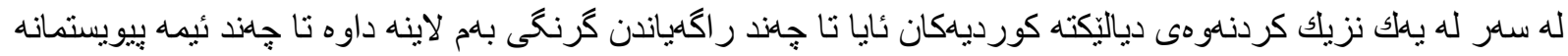

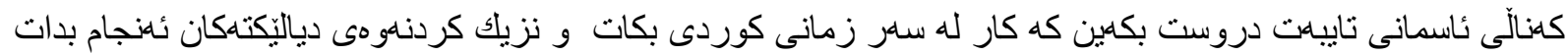

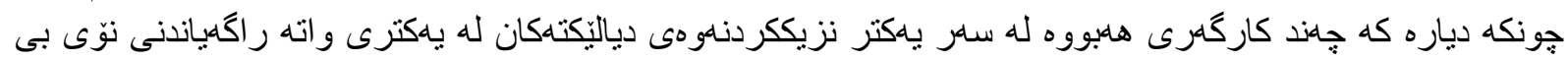

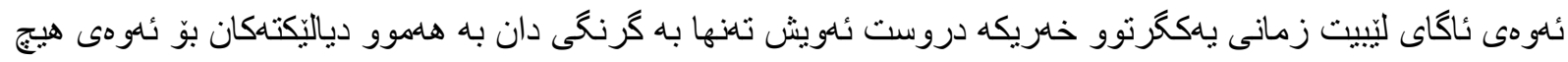

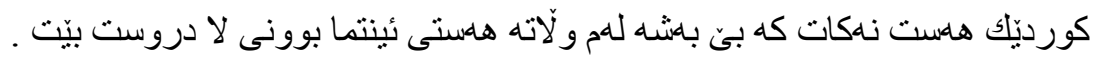

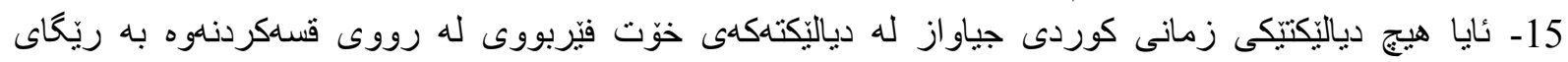

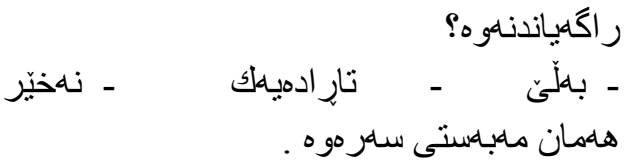




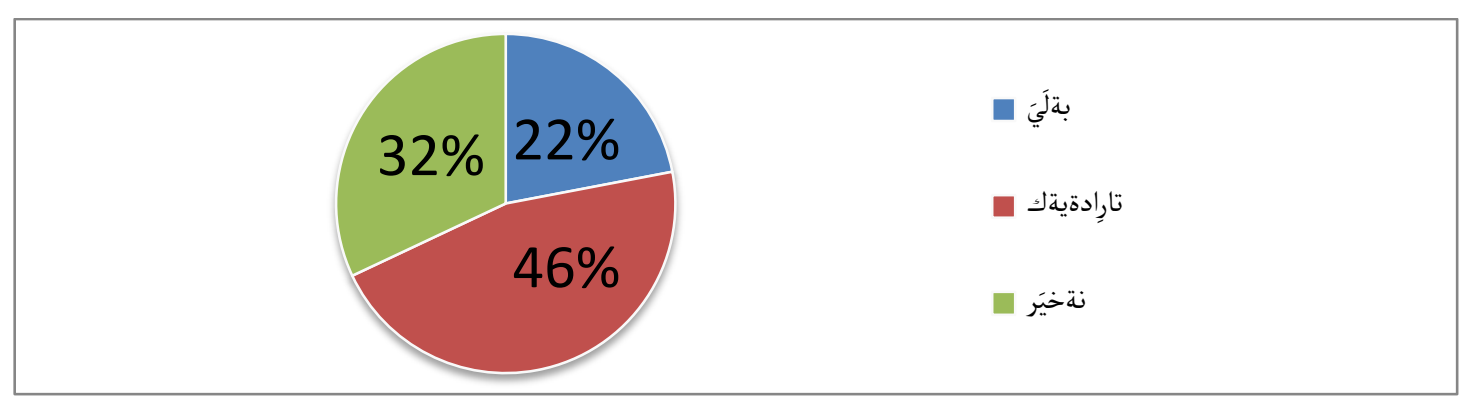

فيكمرى زماره 15

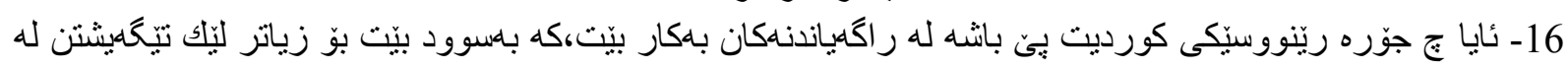

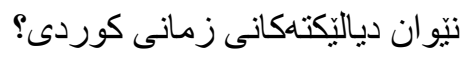

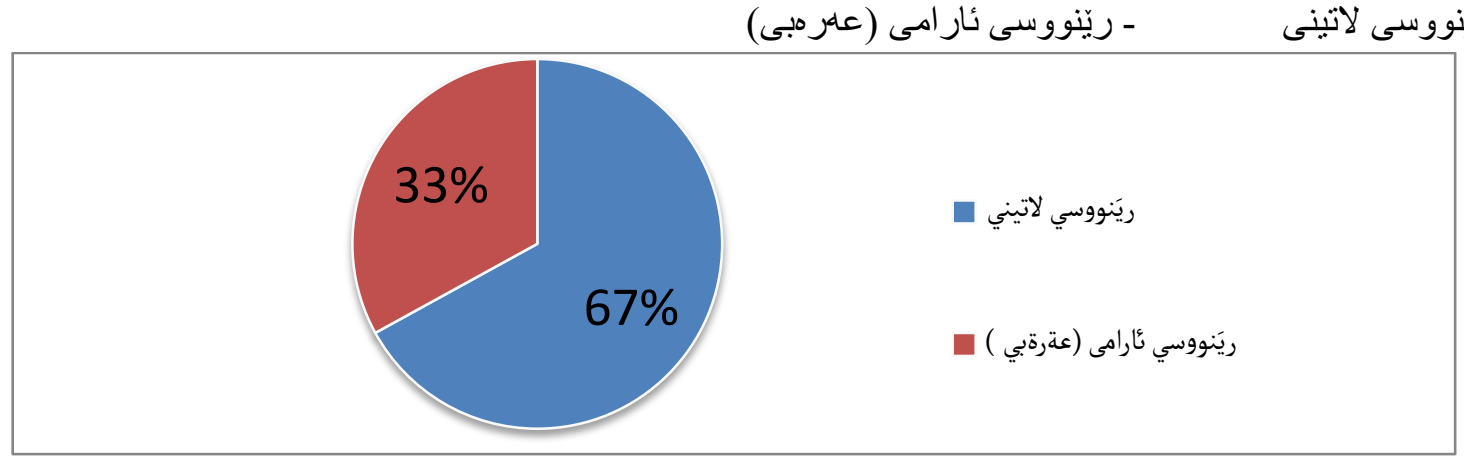

\section{فيكمرى زماره 16}

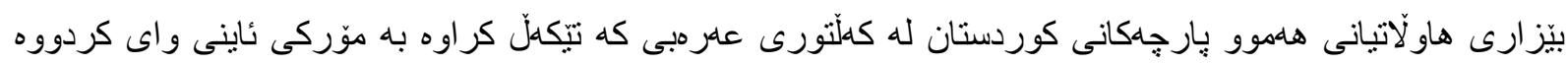

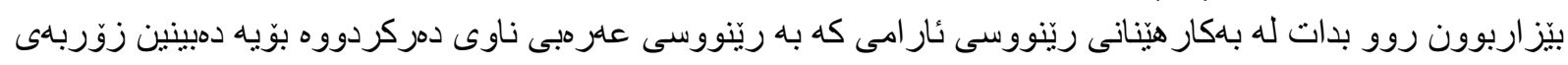

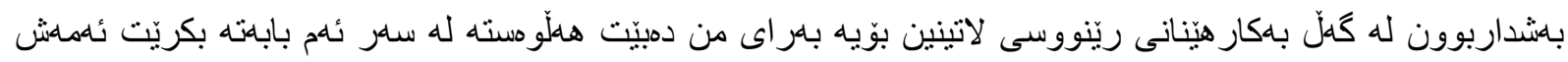

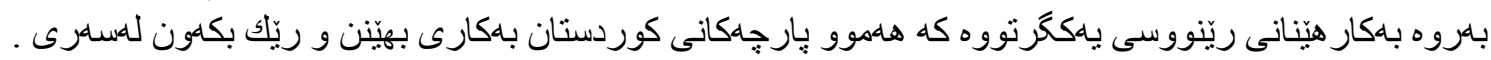

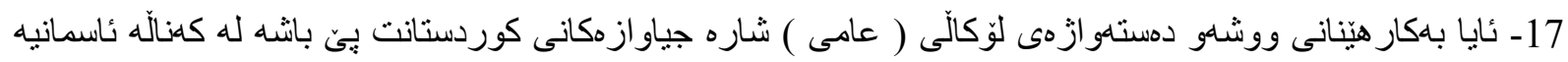

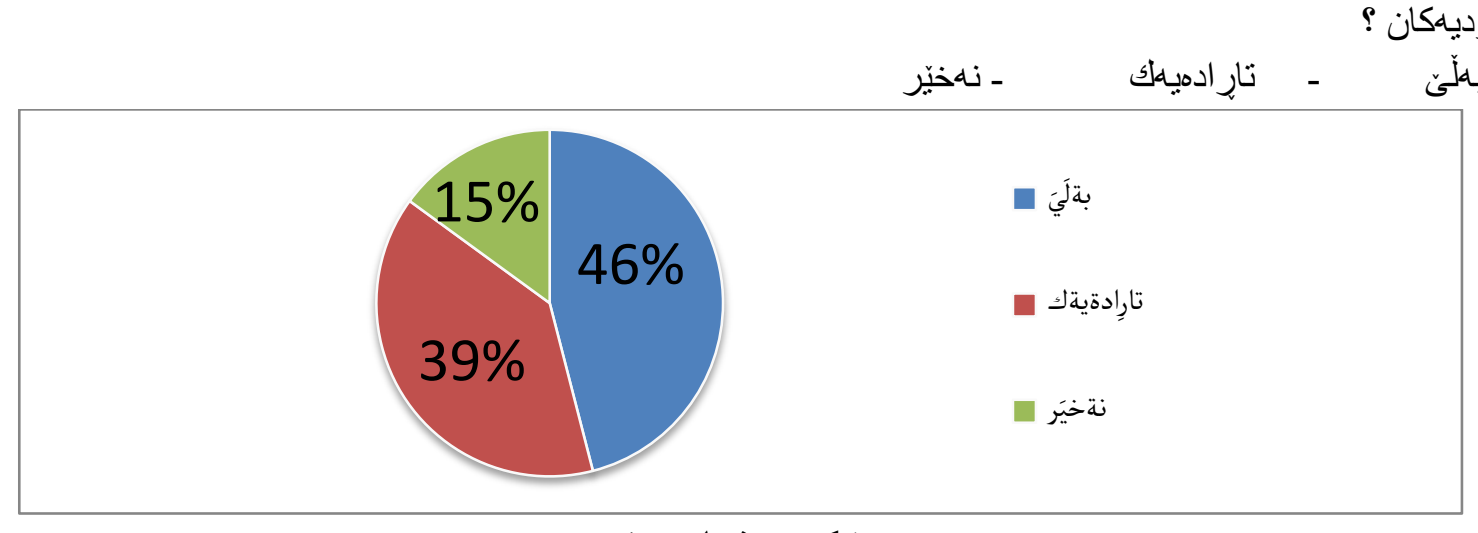

$$
\text { فيكمرى زماره } 17
$$

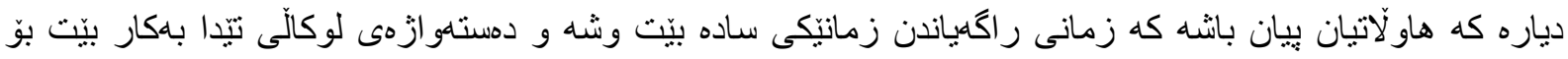

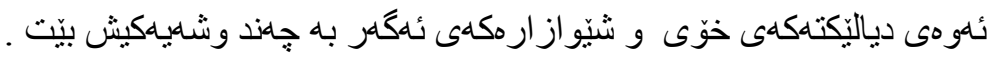

18- به راى توّ كام له كهنالّه ئاسمانيانه نو انيو يانه تنّكهلّى دروست بكهن له نيّو ان دياليّكته كورديهكان؟

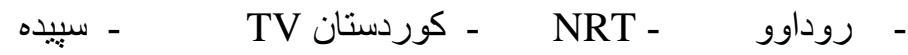

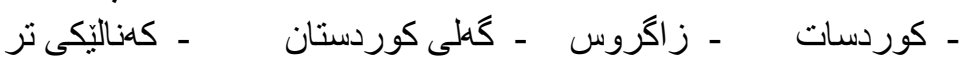




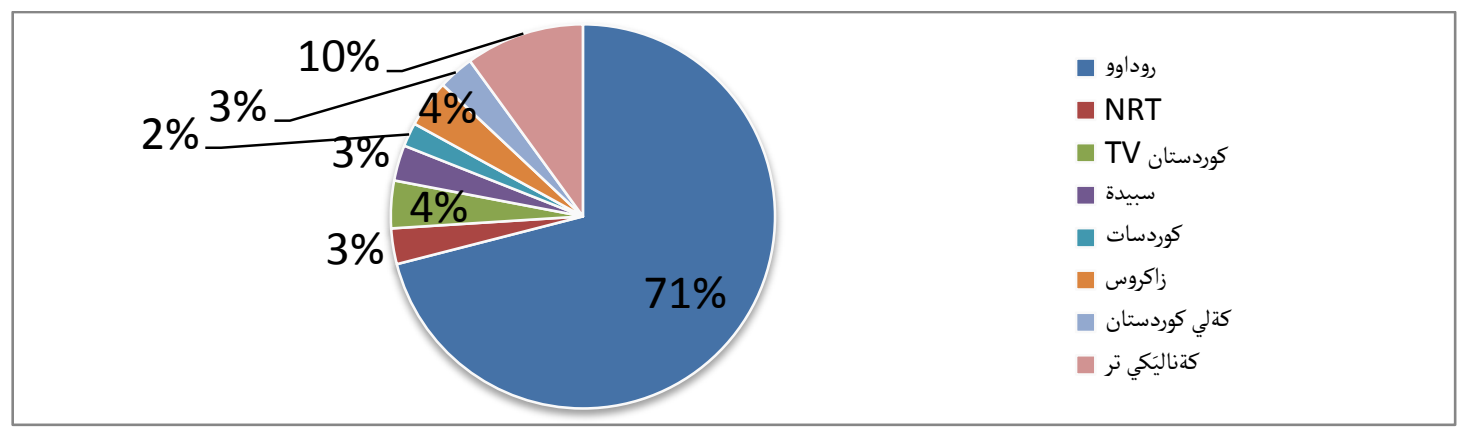

فيكمرى زماره 18

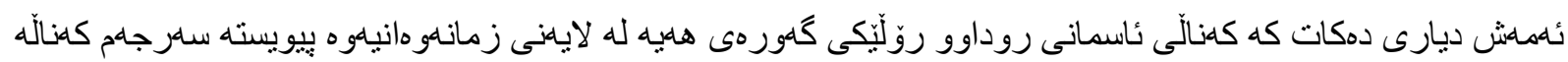

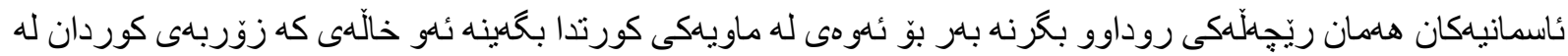

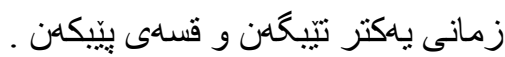

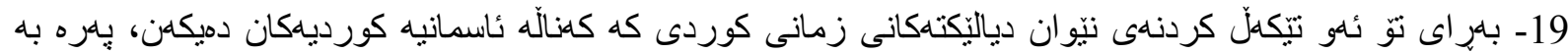

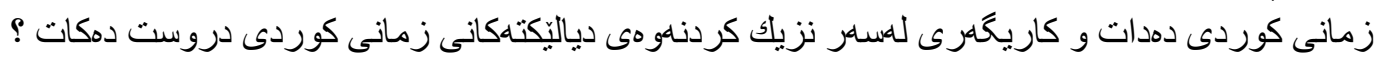
ـ ن ناهنيّر

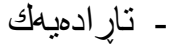

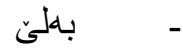

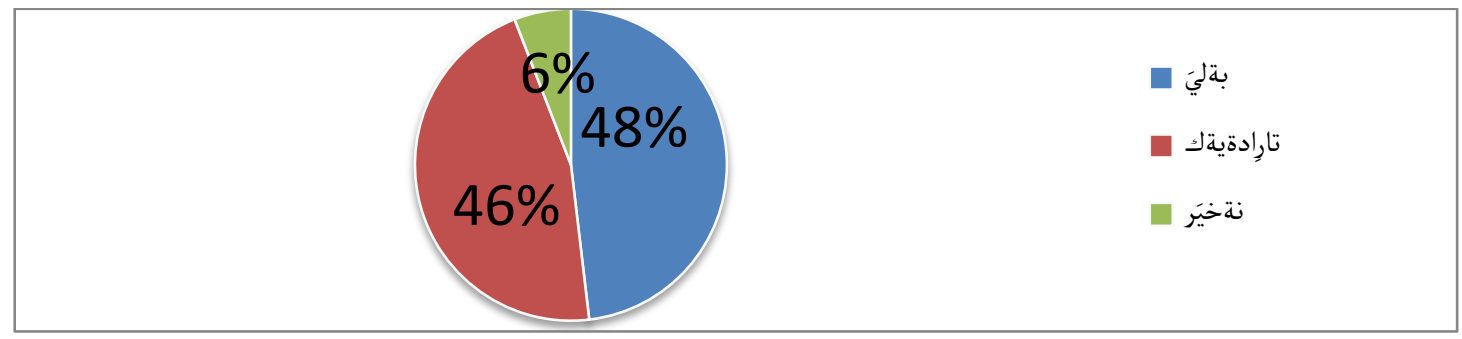

فيكهرى زماره 19

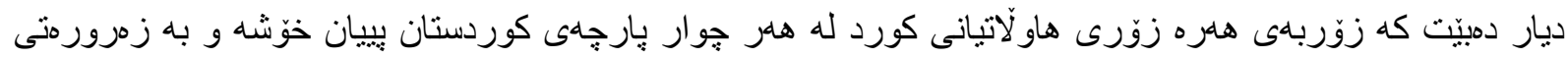

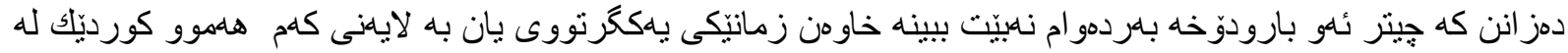

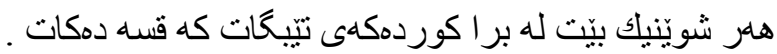

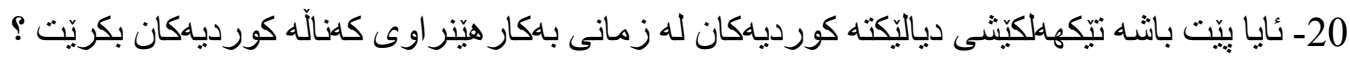

تارِ

$$
\text { فيكارى زماره } 20
$$

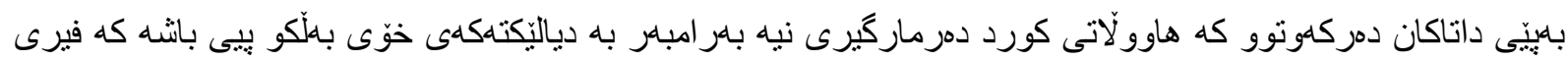

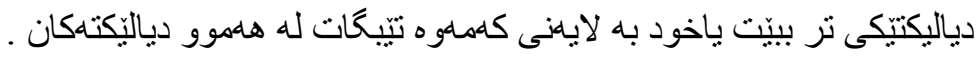

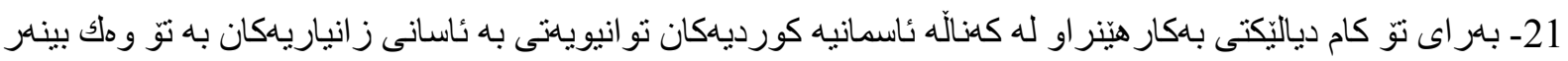
بحانيهنيتب 1 - 2- كرمانجى سارووو

2- 2- كرمانجى خو اروو ( سوّر انىى )

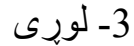

4- كوران وزان إن 


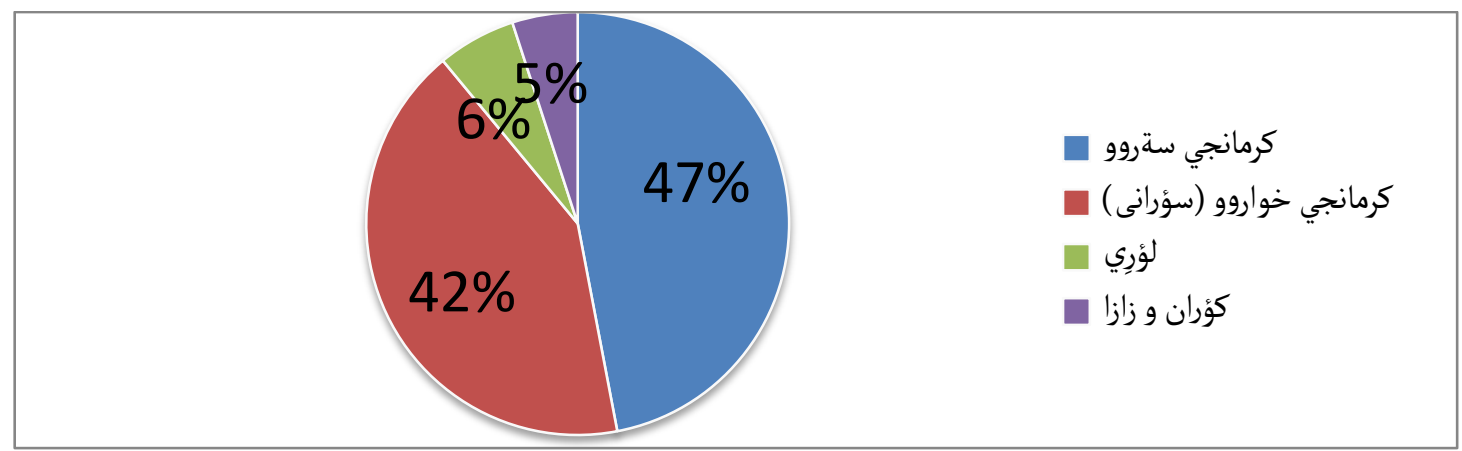

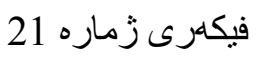

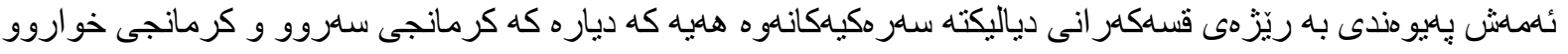

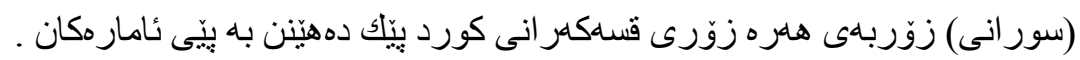

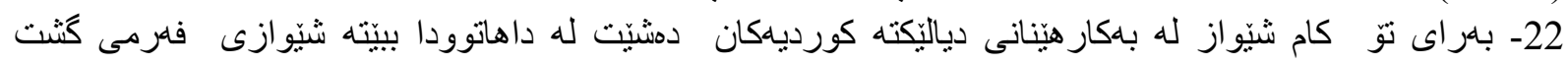

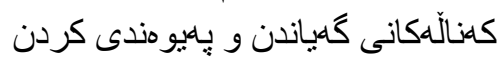

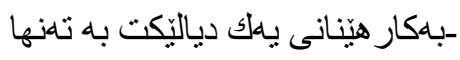

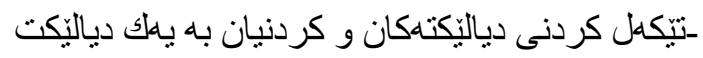

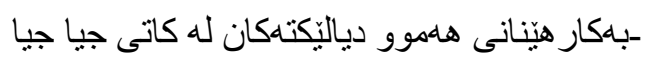

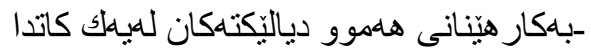

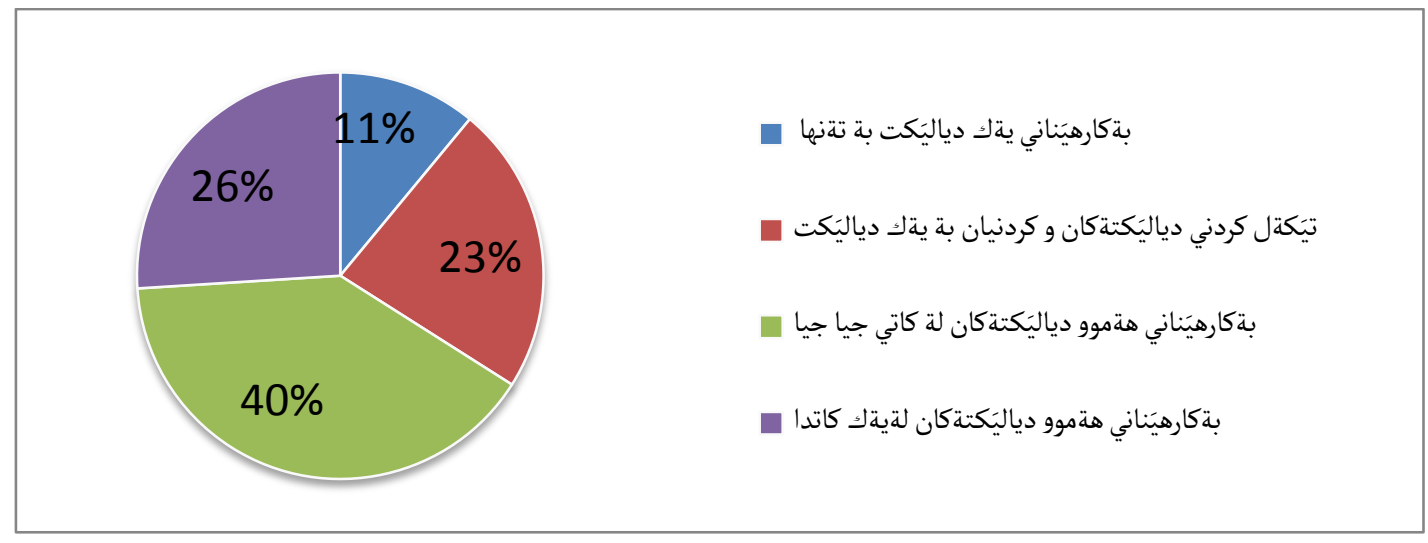

فيكمرى زماره 22

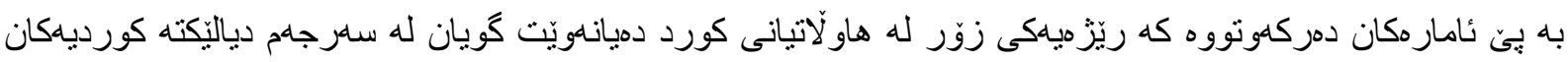

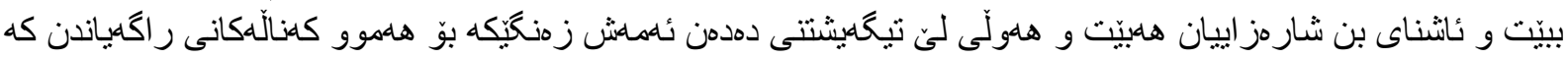

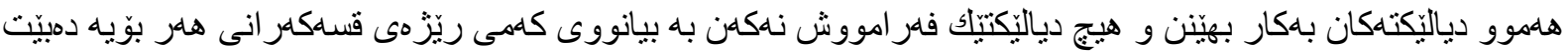

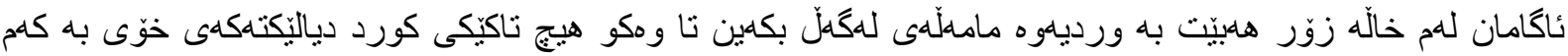

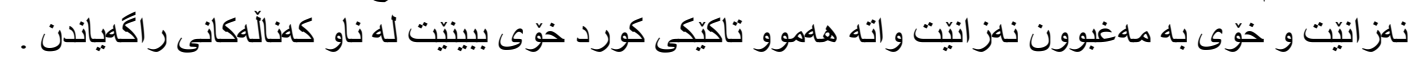
23- ئايا موتابهعاى تورى ميديايى رووداو دمكهيت؟

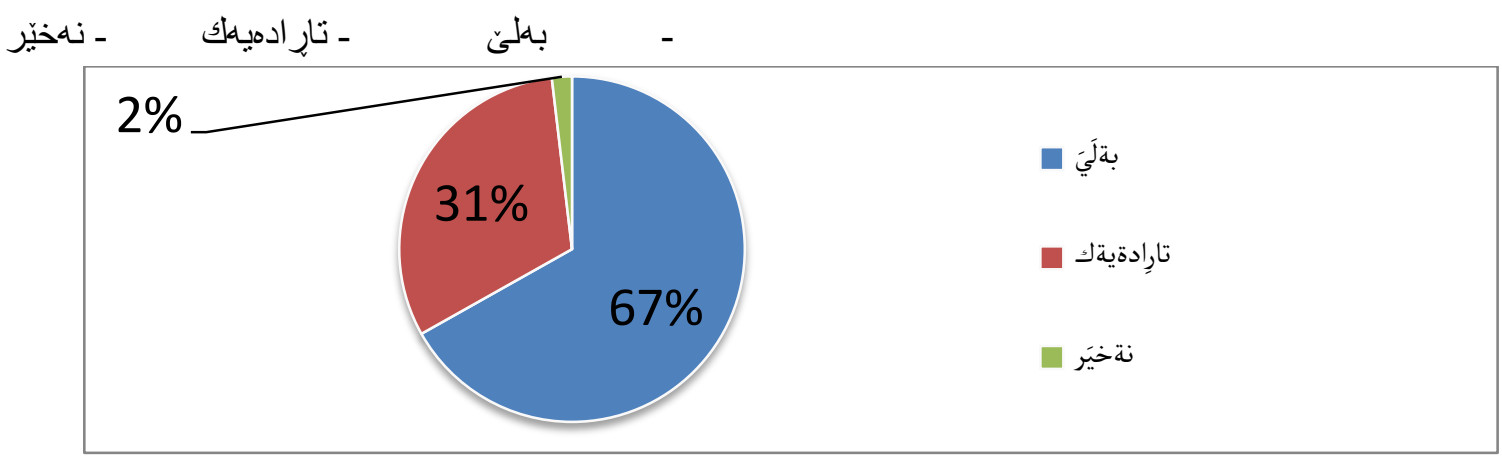

فيكمرى زماره 23 


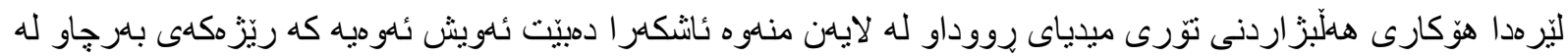

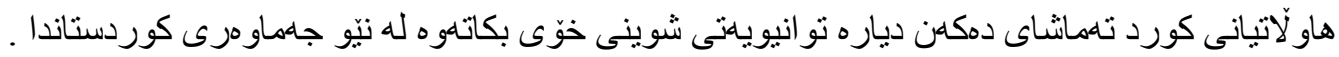

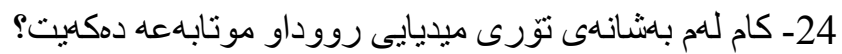

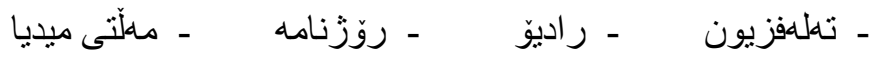

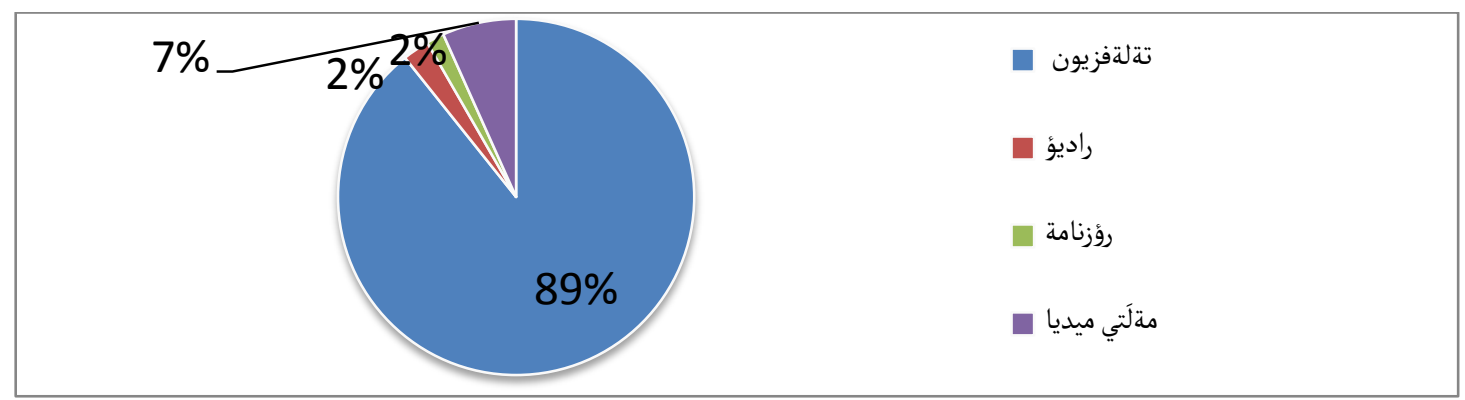

\section{فيكارى زماره 24}

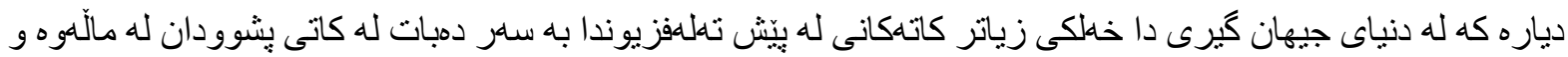

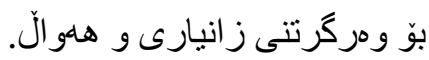

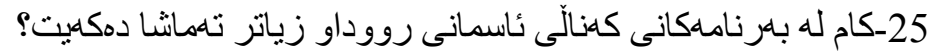

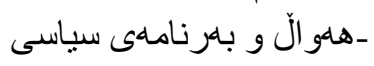

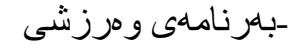

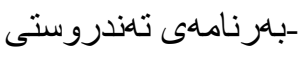

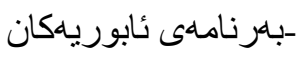

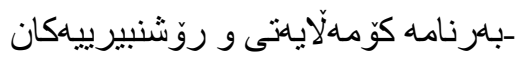

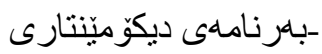

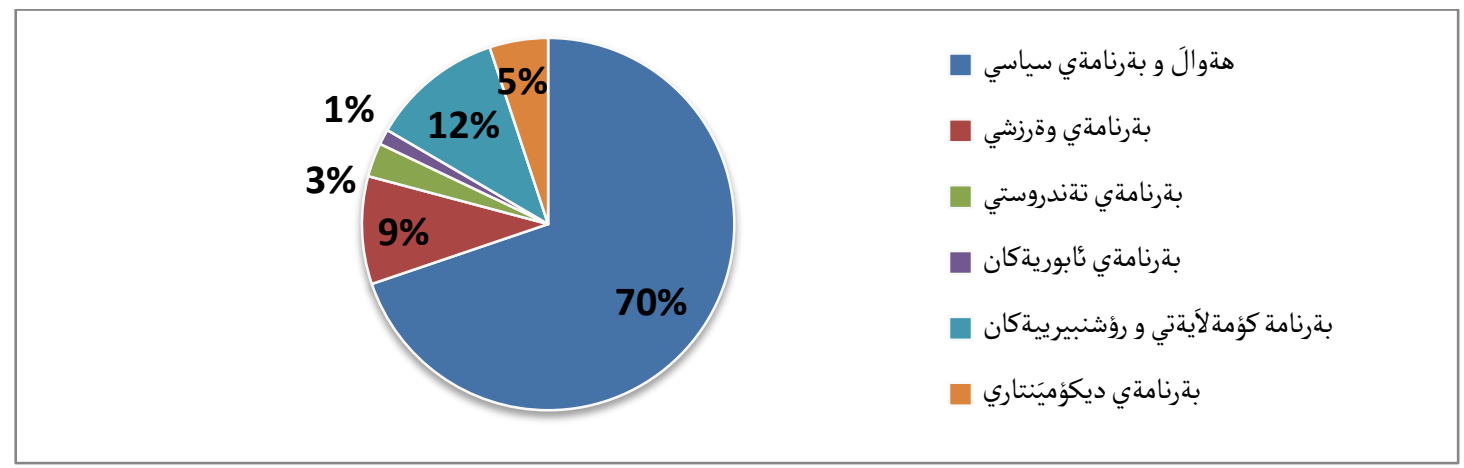

فيكمرى زماره 25

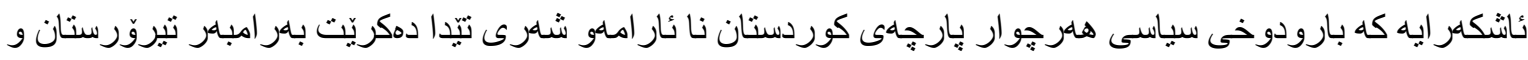

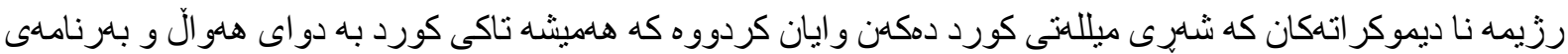

سياسى بيّت

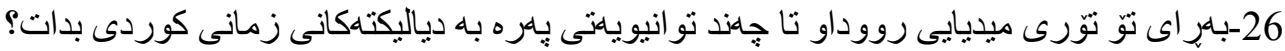

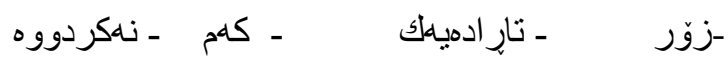

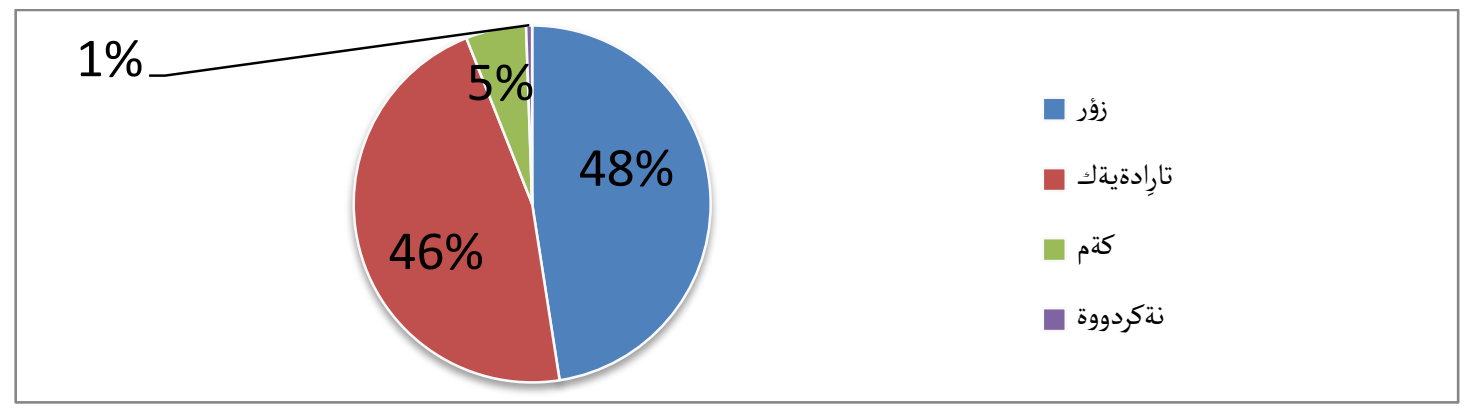




\section{فيكهرى زماره 26}

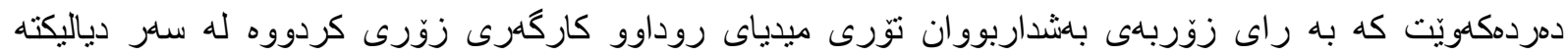

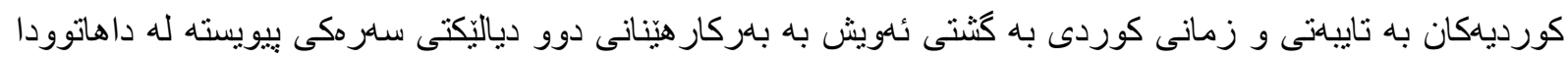

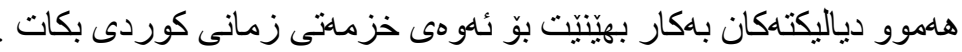

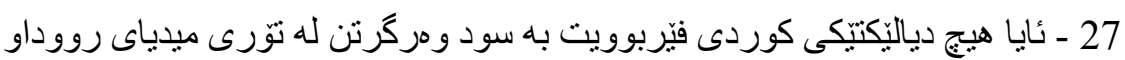

بالَئَ

\section{فيكهرى زماره 27}

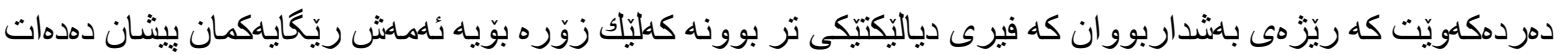

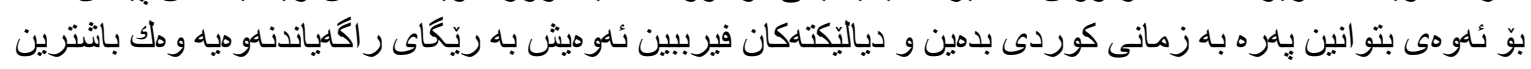

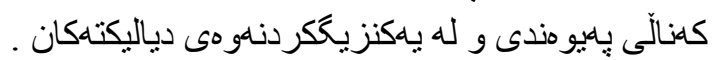

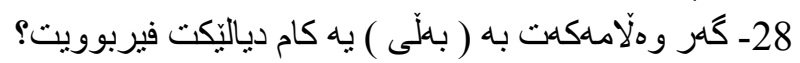
- كرمانجى خو اروو (سوّر انىى) كرمانجى ساروو

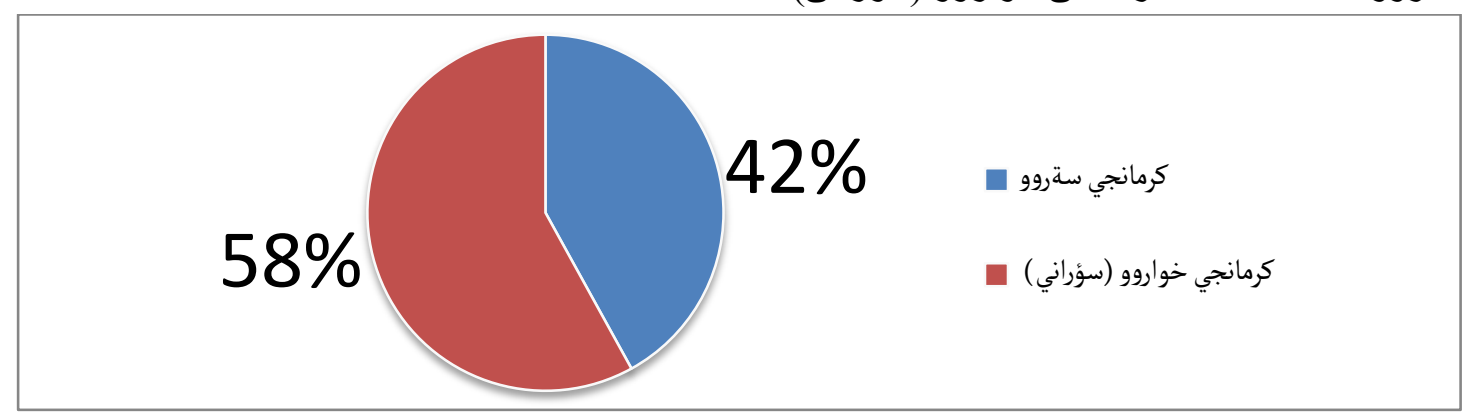

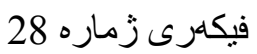

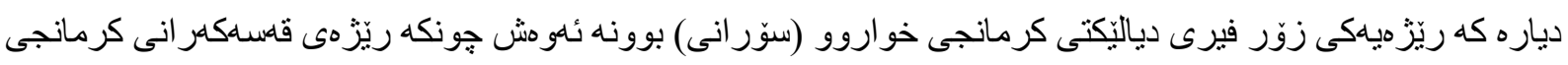

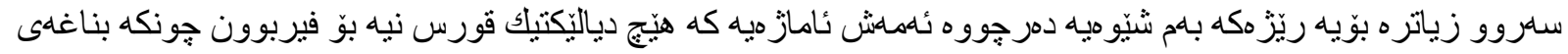

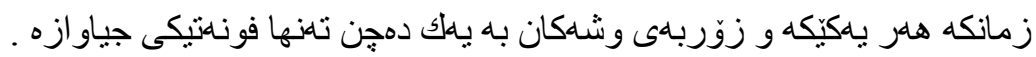

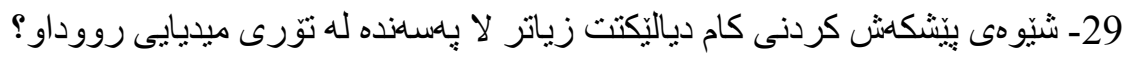

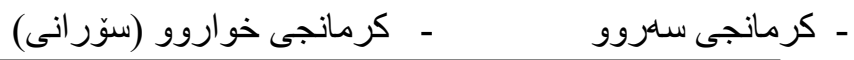

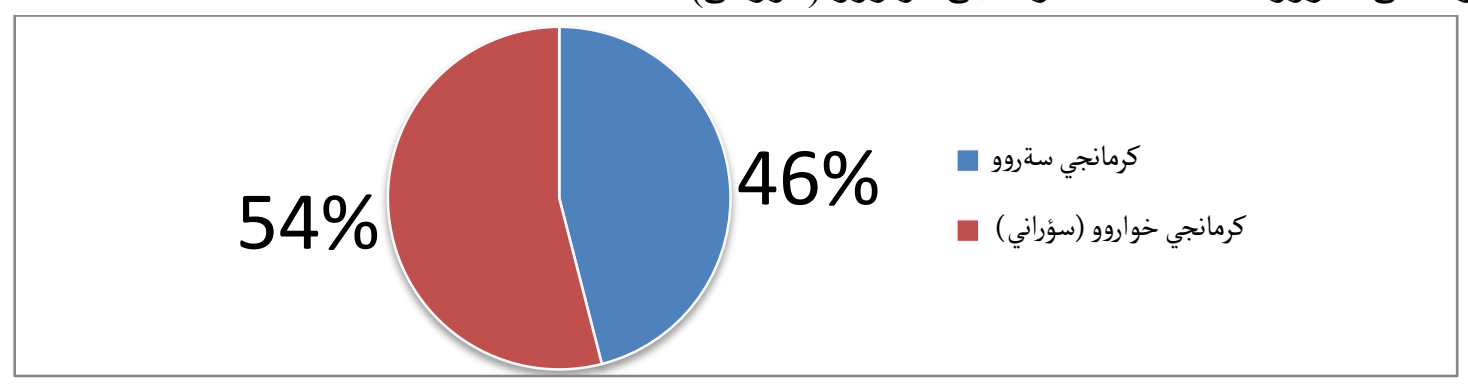

$$
\text { فيكهرى زماره } 29
$$

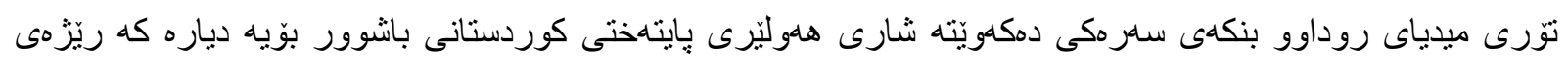

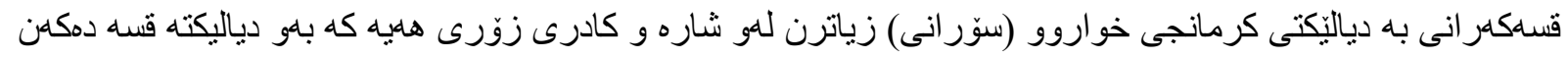

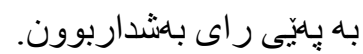

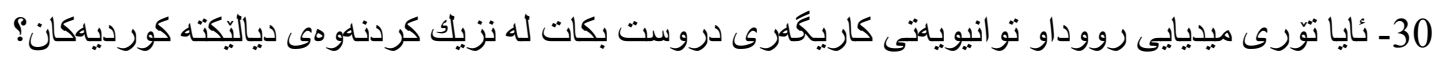




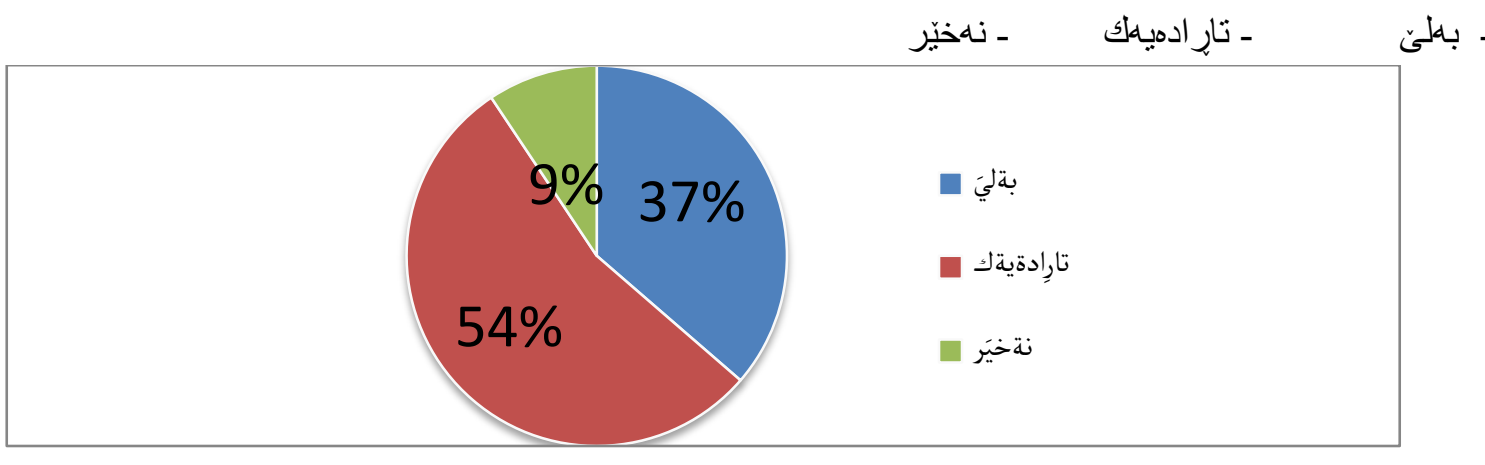

فيكمرى زماره 30

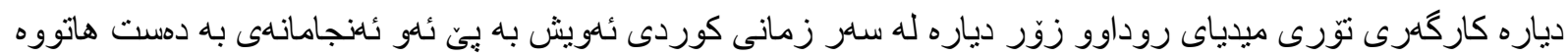

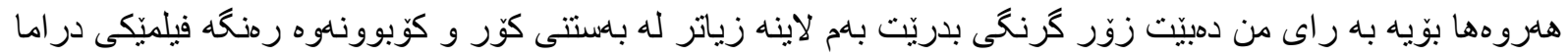

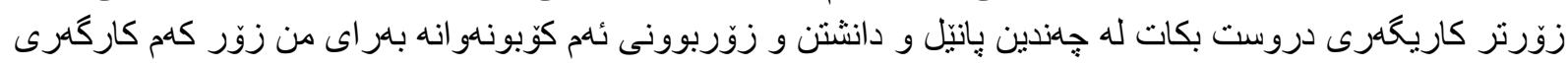

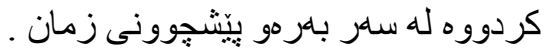

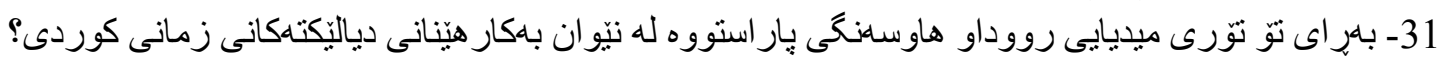
ـ تارِ ادميادكَ

\section{فيكمرى زماره 31 في}

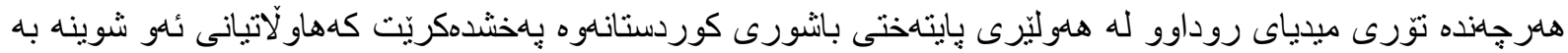

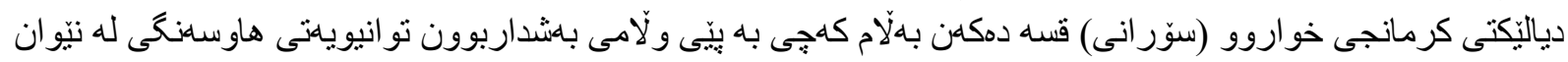

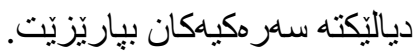

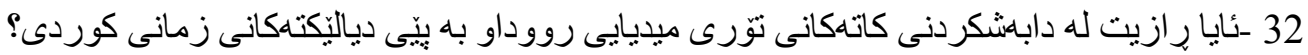

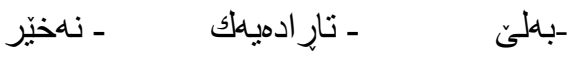

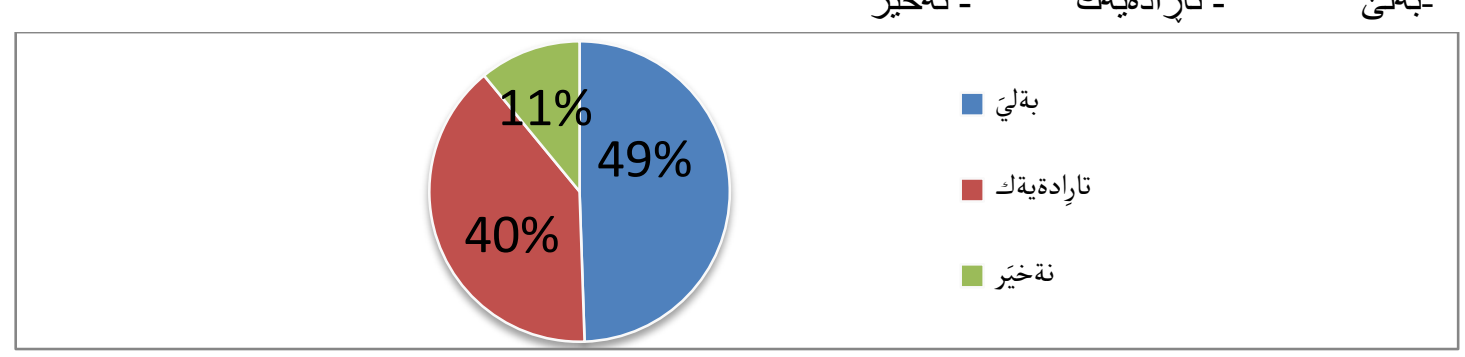

$$
\text { فيكمرى زماره } 32
$$

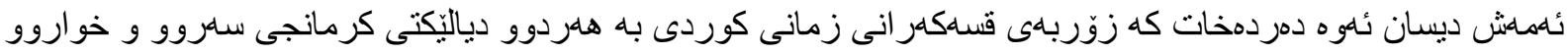

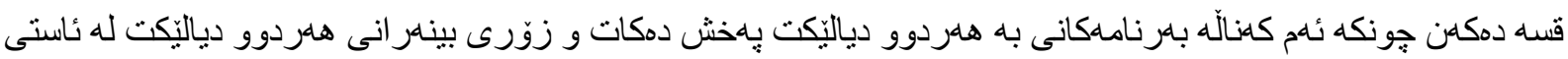

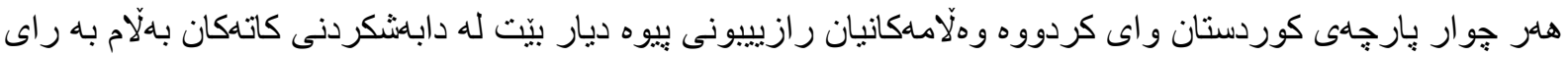

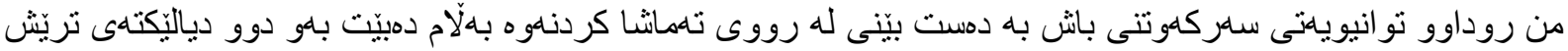

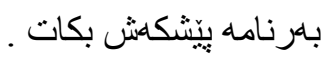

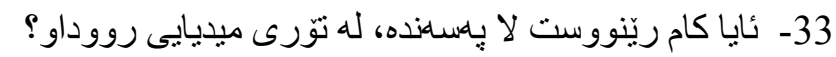
- 


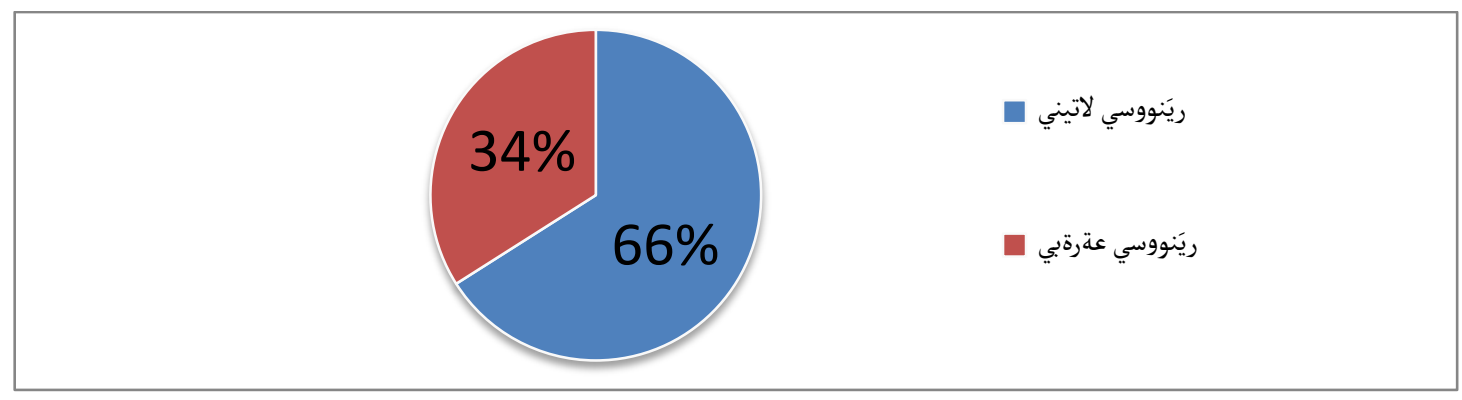

فيكمرى زماره 33

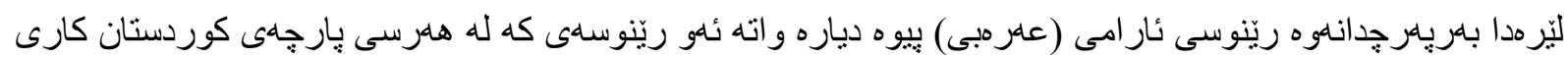

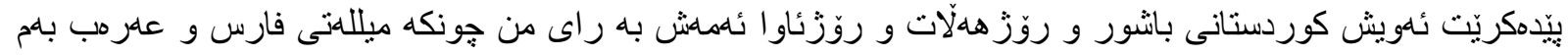

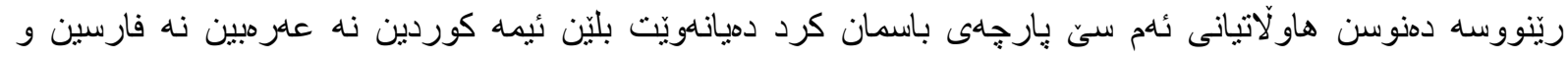

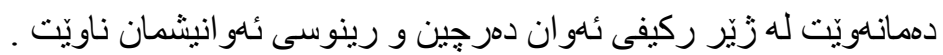

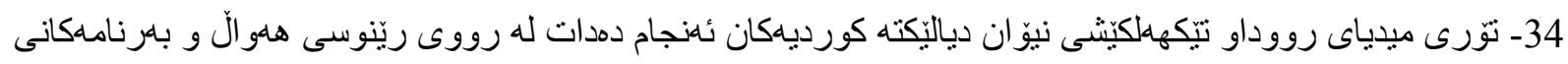

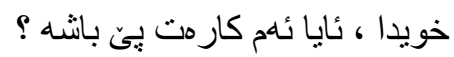

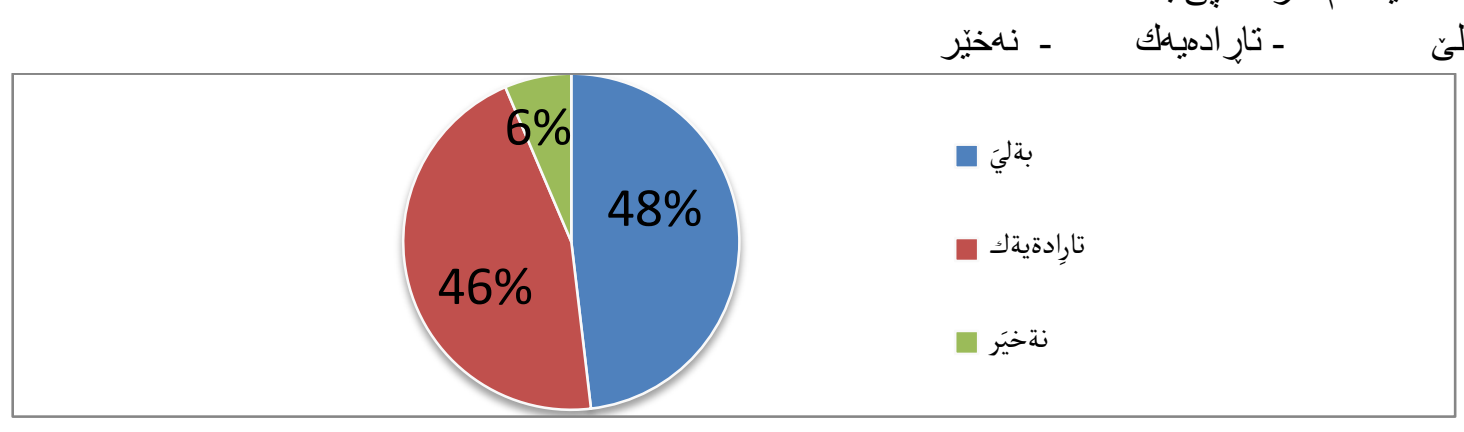

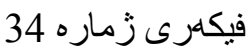

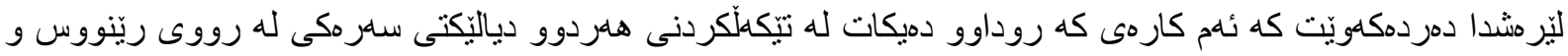

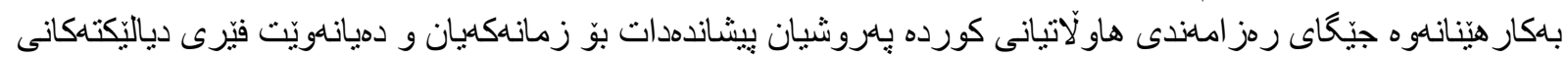

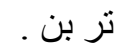

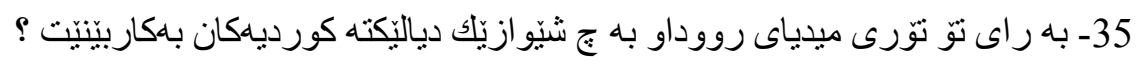
-

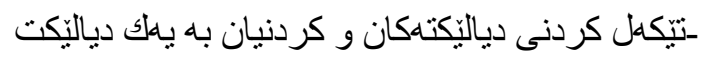

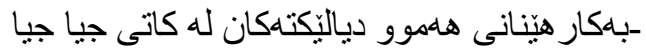

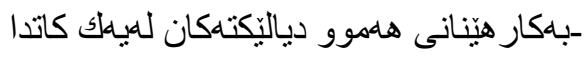
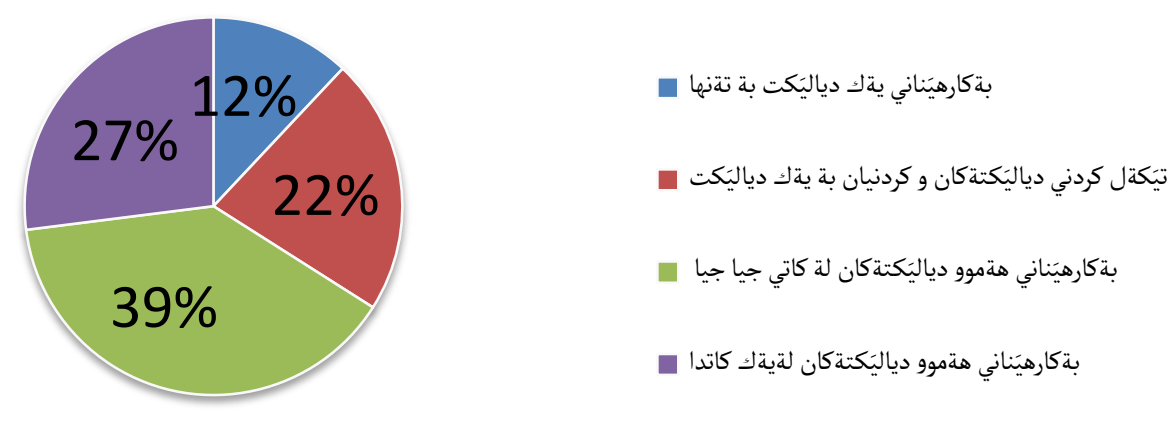

فيكمرى زماره 35

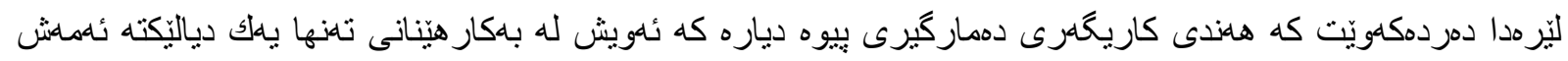

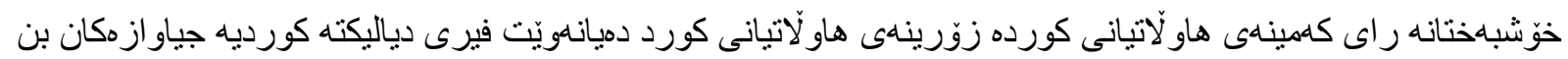

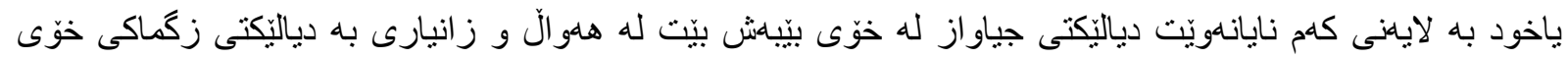




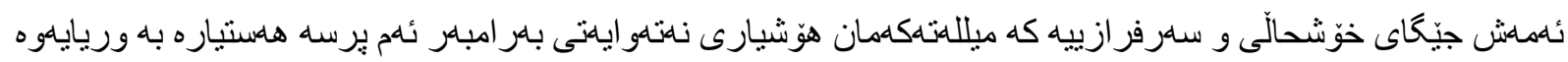

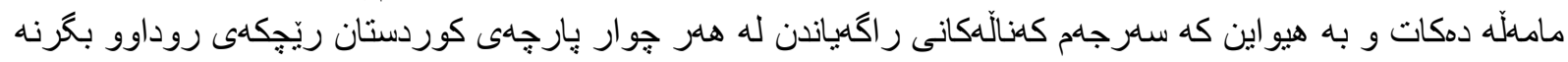

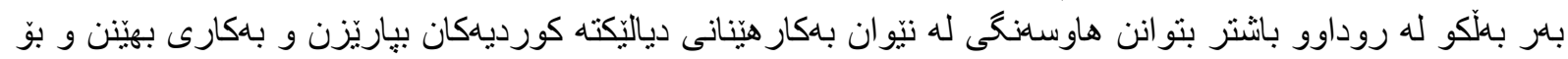

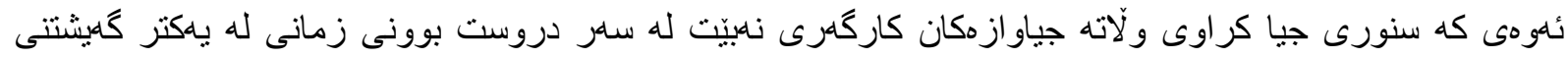

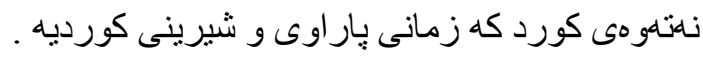

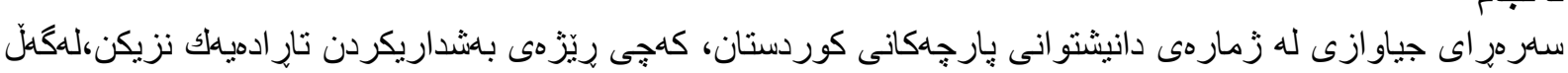

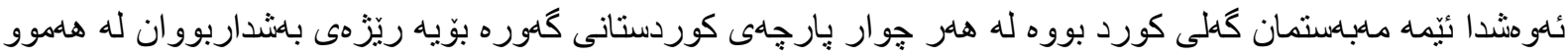

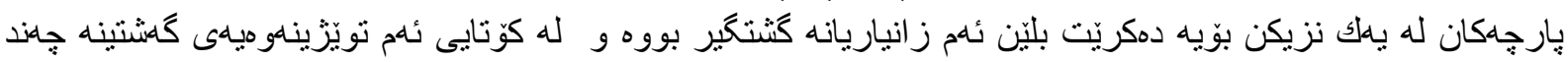

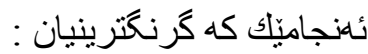

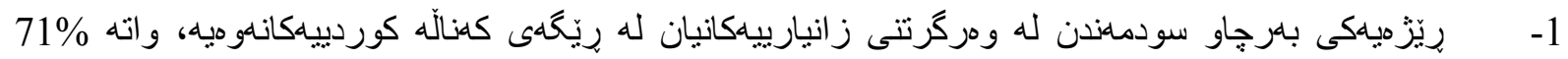

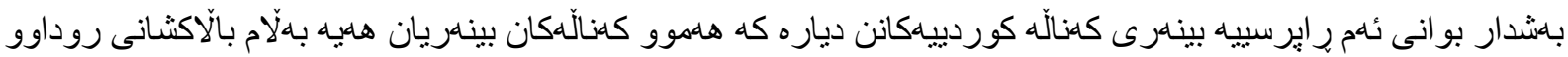

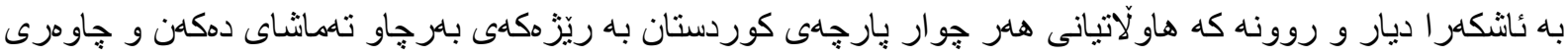

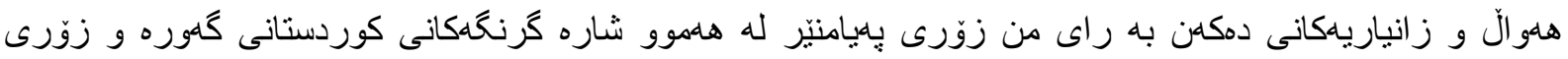

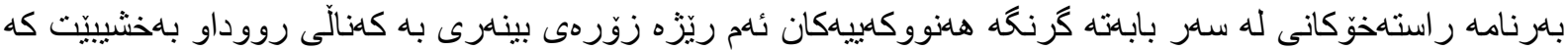

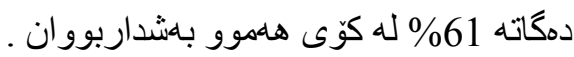

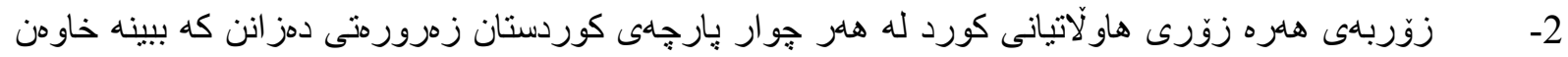

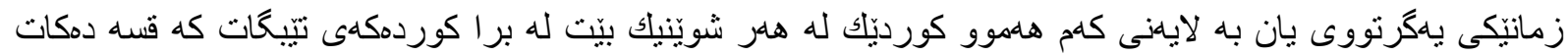

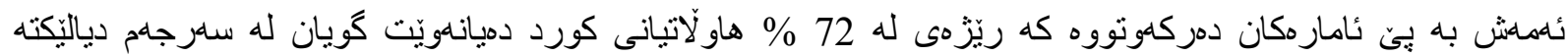

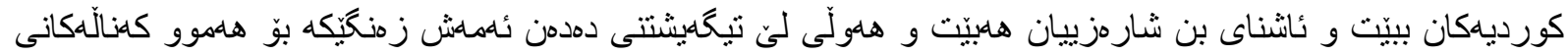

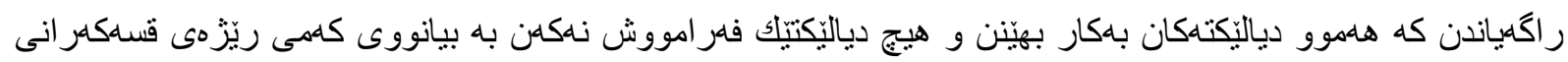

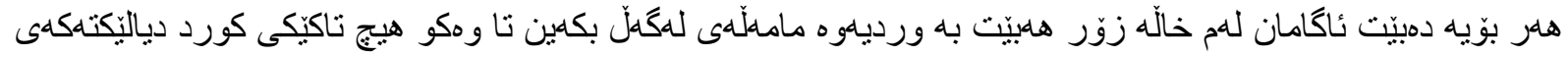

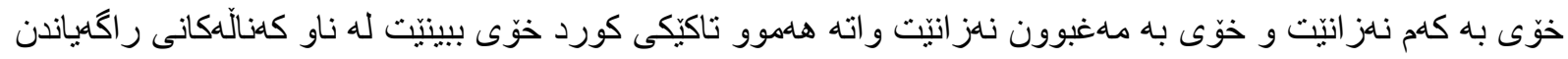

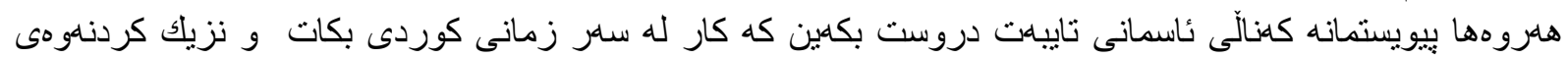

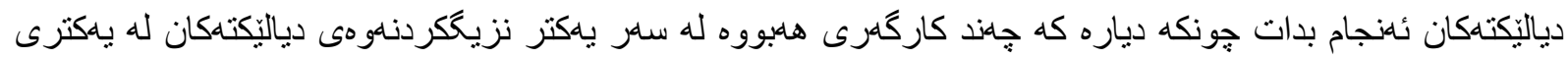

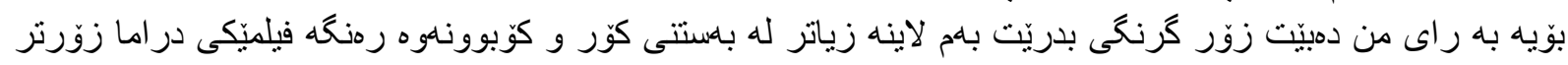

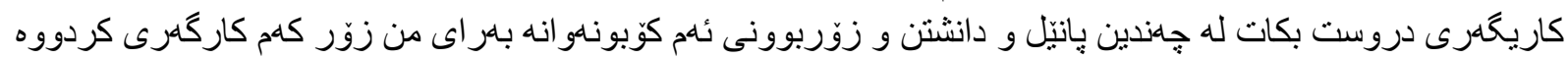

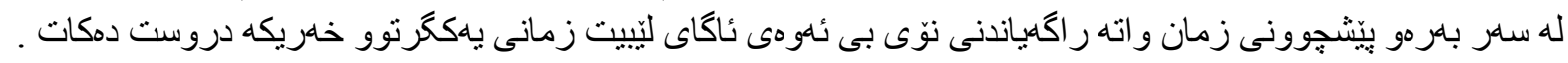

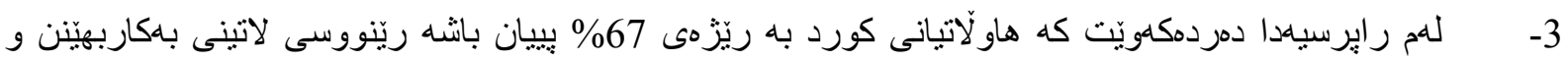

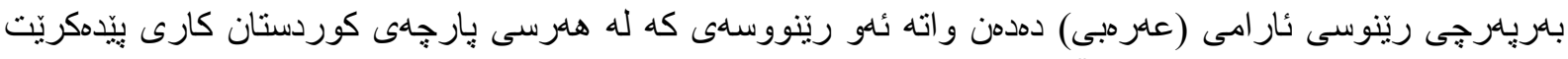

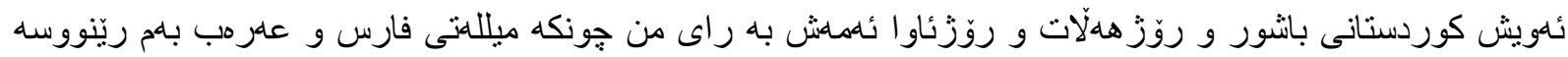

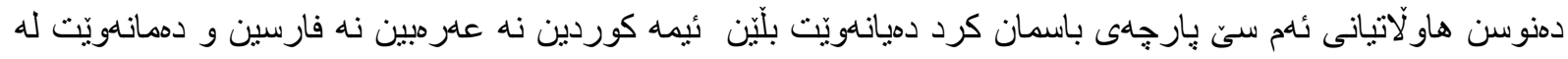

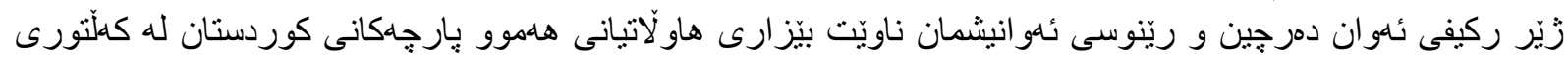

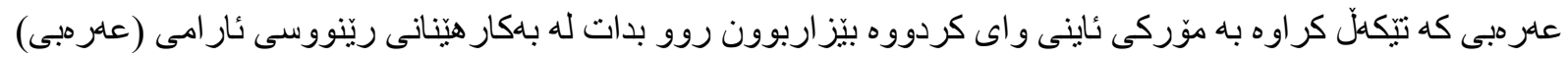

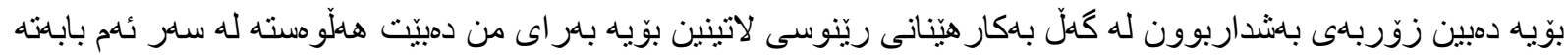

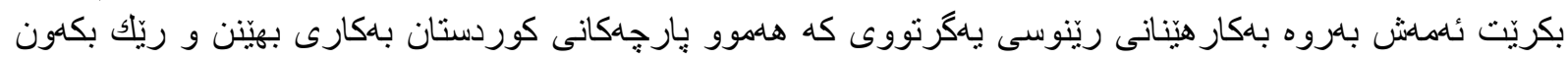

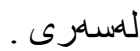

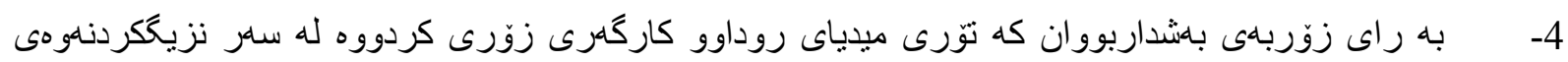

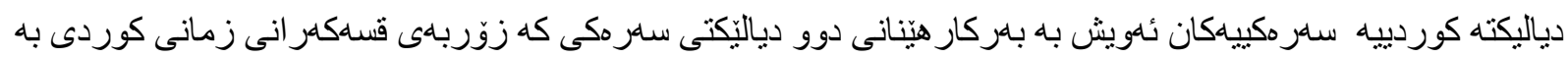

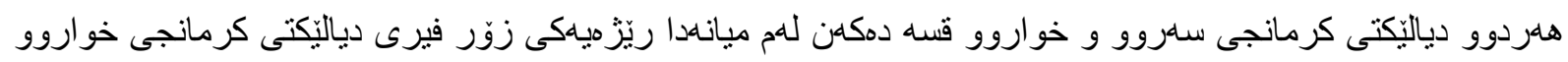

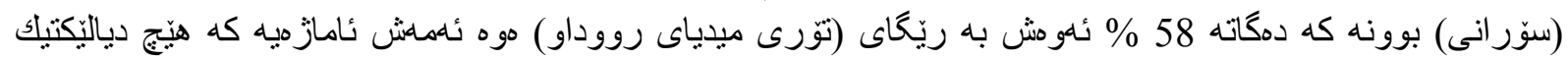

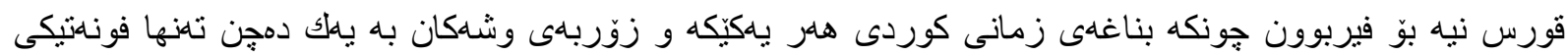

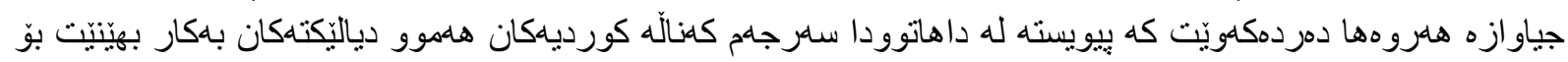




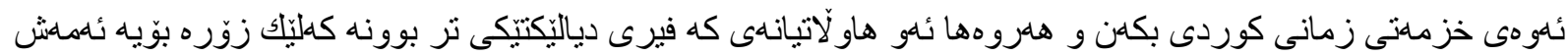

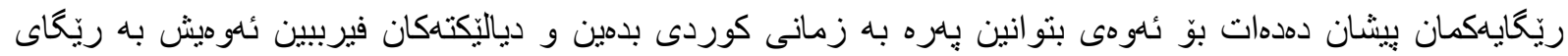

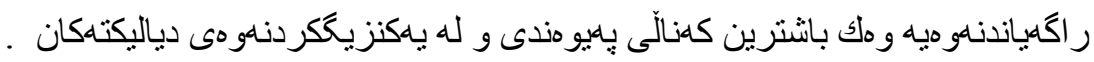

\section{راسبارده}

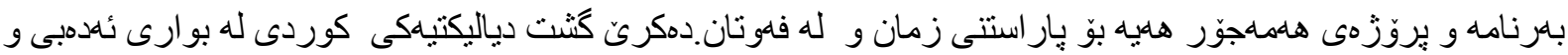

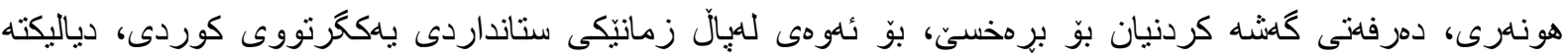

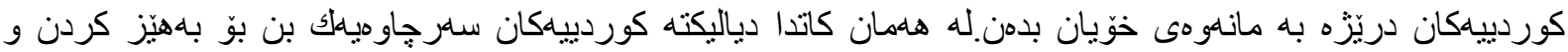

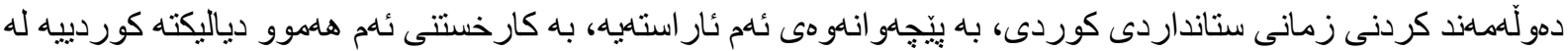

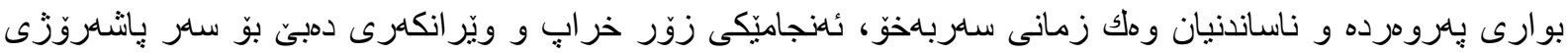

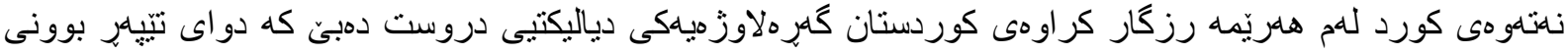

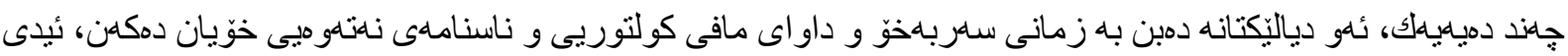

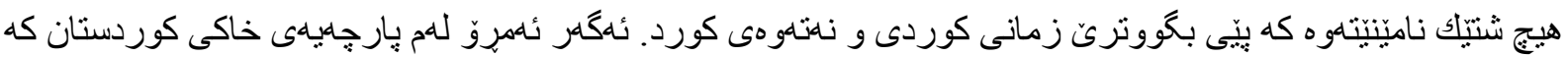

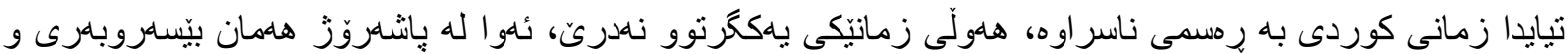

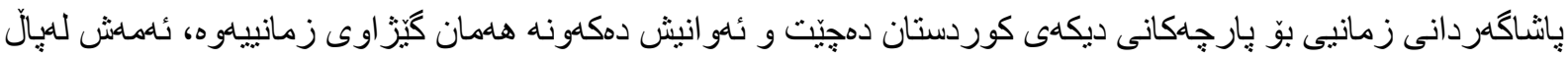

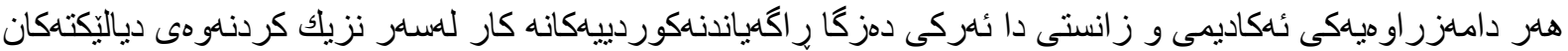

بكان.

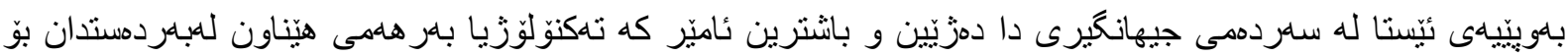

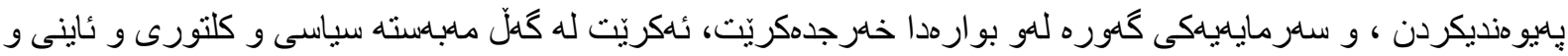

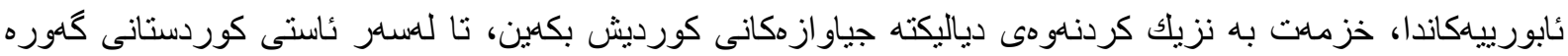

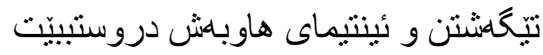

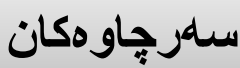

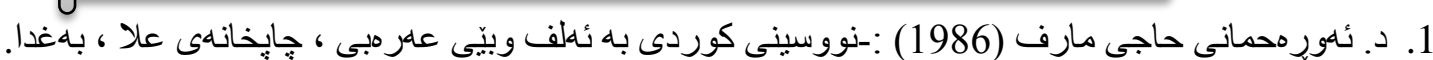

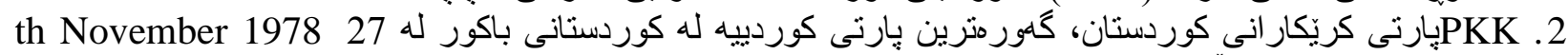
للهلايهن

2015/5/2htth://www.pkkonline.com/en/index.php?sys=article\&artID=175

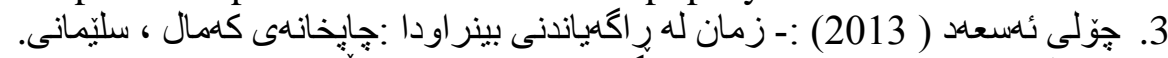

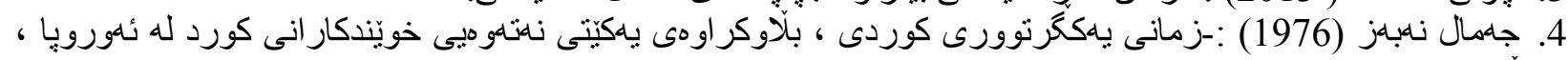
ئهلْمانبا.

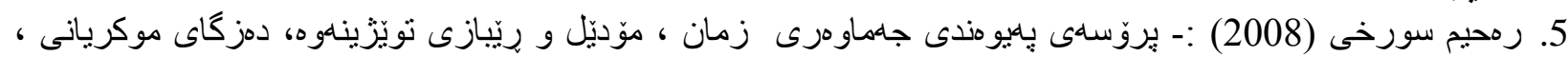
دهوَك.

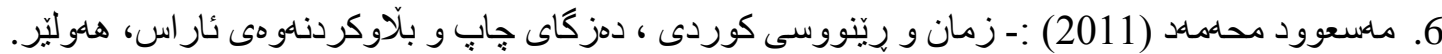

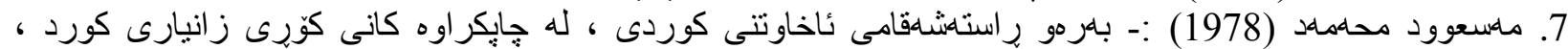

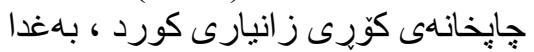

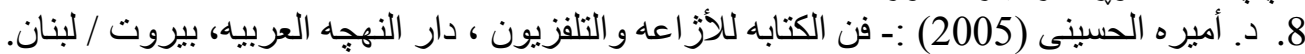

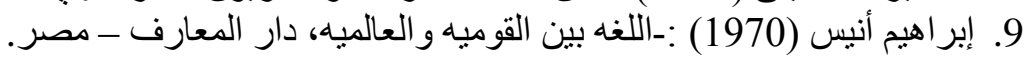

10.أ.د : سامى الثريف ـأبر - د. أيمن منصور ندا (2004) :- اللغه الإعلاميه ( المفاهيم- الأسس - التكبيقات ) جامعه القاهره للتعليم المفتوح ، القاهره

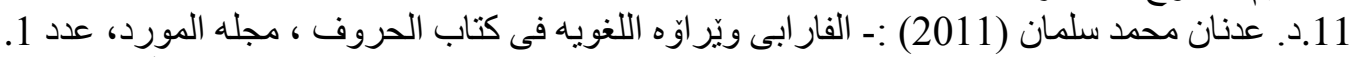
12.د. عبد العزيز شرف (1971) :-الإعلام ولغه الحجاره ، مجله اللسان العربى، العدد 1، الكبعه 11. 


$$
\begin{aligned}
& \text { 13.د. عبد اللكيف حمزه (1984) :- الإعلام و الدعايه ، الهيئه المصريه للكتاب ، كبعه } 2
\end{aligned}
$$

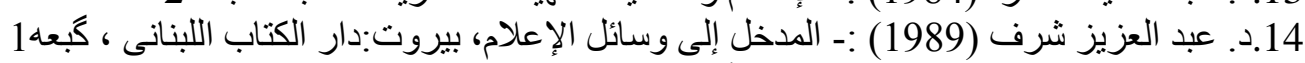

$$
\begin{aligned}
& \text { 15.د. محمد غنيمى هلال(1989) :- النقد الأدبى الحديب ، مكتبه نهجه مصر الإنى ، القاهره. }
\end{aligned}
$$

16. Heinrich Löffler (2006) :-DIALEKT UND STANDARD IM MEDIENZEI TAL TER, Mannheim. 